九州大学学術情報リポジトリ

Kyushu University Institutional Repository

\title{
THE FAMILY CURCULIONIDAE OF JAPAN. I. SUBFAMILY HYLOBXINAE
}

Morimoto, Katsura

Entomological Laboratory, Faculty of Agriculture, Kyushu University

https://doi.org/10.5109/2423

出版情報 : ESAKIA. 19，pp.51-121，1982-11-25. 九州大学農学部昆虫学教室 バージョン：

権利関係 : 


\title{
THE FAMILY CURCULIONIDAE OF JAPAN. I. SUBFAMILY HYLOBIINAE*
}

\author{
KATSURA MORIMOTO \\ Entomological Laboratory, Faculty of Agriculture, \\ Kyushu University, Fakuoka 812, Japan
}

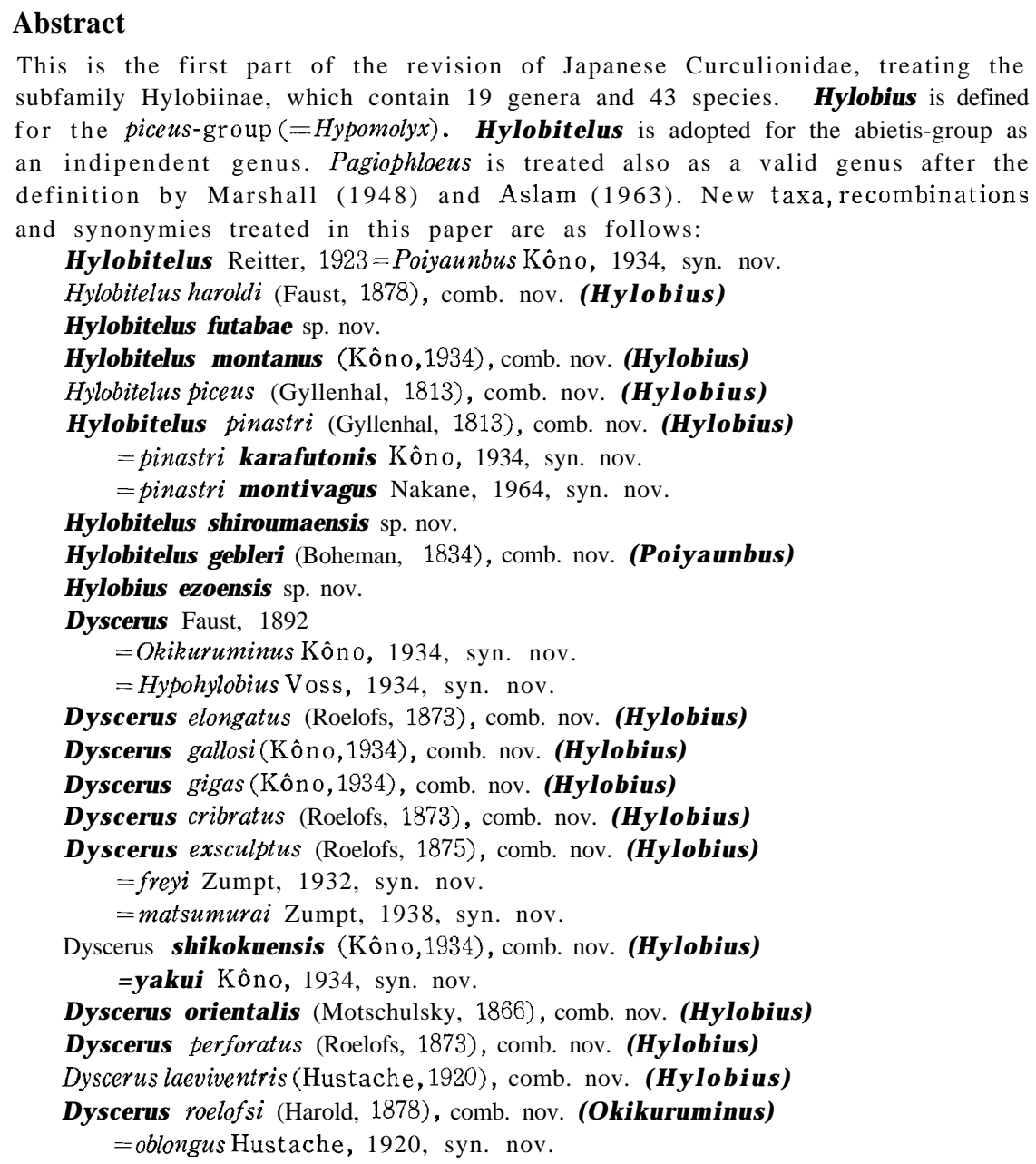

* Contribution from the Entomological Laboratory, Faculty of Agriculture, Kyushu University, Fukuoka (Ser. 3, No. 117). 


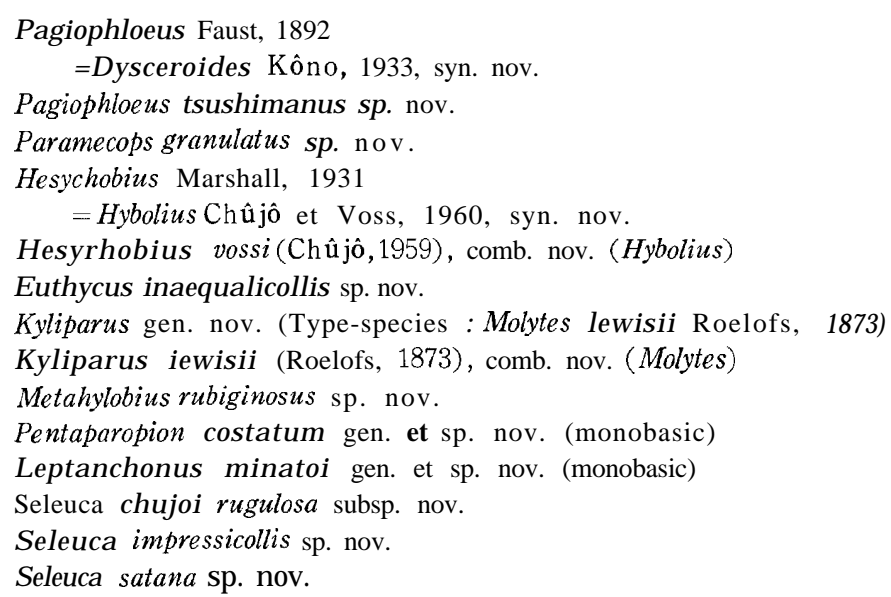

Members of the subfamily Hylobiinae are rather large weevils of the subcortical borers in the larval stage. The first revision of the Japanese species was offered by H. Kôno in 1934. His work is still the most comprehensive and useful treatise available. Since its publication, several species have been added to our fauna by Chûjô (1959), Chûjô and Voss (1960), Morimoto (1961), Nakane (1963, '64), and Voss (1941, '57), and 36 species have been recorded from Japan up to the present.

The purpose of this paper is to provide a well-documented framework of the Japanese species that will serve as a basis for a more extensive treatise of the Asian species.

The definition of the subfamily Hylobiinae treated in this paper is followed after Aslam(1963), who removed the tribe Paipalesomini and the genus Styanax from the Hylobiinae (sensu Marshall, 1932, and Dalla Torre et al, 1932).

Materials. About 1000 specimens of Japanese and 200 specimens of the Oriental species of the Hylobiinae have been examined, and the types in the following collections were also examined : Entomological Institute, Faculty of Agriculture, Hokkaido University, Sapporo ; Department of Zoology, National Science Museum, Tokyo; private collections of Prof. M. Chầjô and Prof. T. Nakane ; British Museum (Natural History), London ; Museum National d'Histoire Naturelle, Paris ; Museum Alexander Koenig, Bonn ; and Naturhistoriska Riksmuseum, Stockholm.

Methods. In addition to the standard characteristics used in the hylobiine weevil identification, I have used the structures of the penis, parameres and internal sac of the male aedeagus. These structures for the diagnosis of the genera and species are either explained or self-evident in the text and illustrations.

Drawings. Structures were observed mostly through a Nikon SMZ stereoscopic microscope and partly through Nikon $\mathrm{S}$ microscope for high magnifica- 
tion, and drawings were made with the aid of an attached drawing tube and a calibrated eyepiece.

Measurements. Body length is the distance from the anterior margin of the forehead to the apex of elytra, and the length of elytra is the maximum distance from the basal margin to the apex parallel to the body axis in a straight line seen right dorsally.

Dissections. In studying the male genitalia the following technique was used: The weevils were relaxed in the Barber's fluid* for one night, then all tergites, ninth sternite and hind wings were pulled out together with the digestive tube, genital organ and muscles by gripping with a pair of fine forceps. These structures were cleared in a hot $10 \% \mathrm{KOH}$ solution for about $10 \mathrm{~min}$. or in a cold solution for one night and then washed in water.

Acknowledgments.

I wish to express my gratitude to Prof. Y. Hirashima, of Kyushu University, for the helpful suggestions and encouragement received throughout the course of this work.

I heartly thank those who sent me specimens for the present study: Dr. K. Baba, Prof. M. Châjô, Mr. H. Ichihashi, Mr. H. Irie, Prof. S. Kimoto, Prof. K. Kojima, Dr. Y. Kurosawa, Mr. H. Makihara, Mr. T. Matoba, Mr. T. Mikage, Mr. S. Kiyakawa, Mr. Y. Miyake, Prof. Mt. Y. Miyatake, Prof. Y. Murakami, Prof. H. Sasaji, Prof. T. Shirôzu, Dr. S. Uéno, and many other friends.

The following entomologists permitted me to visit and examine specimens in their care; they were warmly hospitable: R. C. Thompson (London), H. Perrin (Paris), H. Roer (Bonn), L. Brundin and T. Nyholm (Stockholm), C. Watanabe and S. Takagi (Sapporo), Y. Kurosawa and S. Uéno (Tokyo), M. Chûjô (Nagoya), and T. Nakane (Kagoshima).

\section{K EY TO THE TRIBES AND SUBTRIBES}

1(2) : Prosternum excavated, each side of the excavation carinate......... Tribe Lithinini

2(1): Prosternum not excavated.

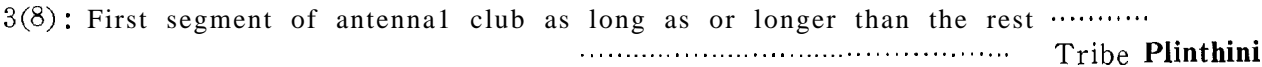

4(5): Rostrum separated from head by depression or its dorsal outline forming an angle with forehead; head very shiny, bare and almost impunctate ; elytra without humeri; hind wings rudimentary ........... Subtribe Anchonina

5(4): Rostrum with its dorsal outline continuous with forehead; head with normal punctation or scaling.

6(7): Antenna1 scrobes entirely visible laterally, its dorsal margin directing to the middle of eye Subtribe Plinthina

$7(6)$ : Antenna1 scrobes passing beneath the base of rostrum

Subtribe Leiosomatina

$8(3)$ : First segment of antenna1 club much shorter than the rest ........ Tribe Hylobiini

* The formula is quoted here from Valentine (1943), modified. Benzene 27 cc, Ethyl acetate $74 \mathrm{cc}, 50 \%$ Ethyl alcohol $399 \mathrm{cc}$. 
9(10): Elytra with a distinct humeral callus

Subtribe Hylobiina

10(9): Elytra without a humeral callus; hind wings rudimentary Subtribe Liparina

Tribe Hy LOBIINI

The tribe Hylobiini treated here is equivalent to Hoffmann's Curculionini and Marshall's Hylobiini plus Liparina.

Marshall (1932) laid stress on the importance of the presence or absence of the humeral callus and the width of the intercoxal process for the grouping of Hylobiinae. These characters change, however, in accordance with the reduction of the hind wings and not always connected with the phylogenetic relationships in some cases. The degree of the reduction of the hind wings can be classified into three steps. The first step is the reduction of the apical part of the hind wings as seen in Hylobius adachii (Fig. 13) and H. ezoensis. Their elytra are weakly rounded laterally and widest in the middle, and the metasternum is not shortened. The second step is the reduction of both length and width of the hind wings (Fig. 42). Adults of this type have reduced humeri, shorter metasternum and wider abdominal process as seen in some brachypterous species. The third step is the advanced stage of the second. The hind wings are rudimentary, the metasternum is much shorter and the abdominal process is wider than a hind coxa.

Poiyaunbus Kôno and Hylobitelus Reitter are apparently named for the brachypterous species (first step) of the abietis-group.Okikuruminus Kôno and Hypohylobius Voss are also named for the brachypterous species of the laeviventris-group. Liparus Olivier and Kyliparus gen. nov. are also close to DyscerusHylobius genera in some points excepting the characters related to the reduction of the hind wings as mentioned above.

\section{KEY TO THE GENERA OF HYLOBIINI}

1(18): Elytra with rectangular or rounded humeral callus.

2(3): Antennal club visibly two-segmented; tarsal groove with two "rows of outer setose fringes; internal sac of penis with five lobes internally ........

Aclees Schoenherr

$3(2)$ : Antennal club visibly three- or four-segmented; tarsal groove with a row of outer setose fringe.

4(7) : Pronotum without postocular lobes, anterior margin of prosternum shallowly sinuate ; second segment of antennal funicle longer than the first; outer setose fringe of tarsal groove apical and not clearly oblique to the axis of tibia.

5(6): Eyes lateral

Lepyrus Schoenherr

6(5): Eyes approximate to each other on the underside of head ; derm covered with white scales .................................................. Hesychobius Marshall

7(4) : Pronotum with distinct postocular lobes; anterior margin of prosternum deeply emarginate; second segment of antennal funicle shorter than the first.

8(9): Forehead between eyes as broad as or broader than the base of rostrum; outer setose fringe of tibiae terminal …............................. Kobuzo Kôno 
$9(8)$ : Forehead between eyes narrower than the base of rostrum.

10(11): Outer setose fringe of tarsal groove terminal and not clearly oblique to the axis of tibia

Paramecops Schoenherr

11(10): Outer setose fringe of tarsal groove oblique.

12(13): Fore tibiae strongly curved at base and straight at apex externally, strongly expanded internally at basal third; rostrum with a small median projection at apex; antennal club with apical margins of first and second segments partly oblique to the axis of club

Pagiophloeus Faust

13(12): Fore tibiae straight or weakly curved externally at base ; rostrum without a median projection at apex (except for orientalis).

14(17): Antennal club oval, first segment as long as or longer than the second; seventh segment of funicle dilated apically and annexed to club; rostrum with furrows above scrobes and without dorsal furrows; fore tibiae straight at apex externally; outer setose fringe of hind tibiae weakly oblique ; metasternum without a transverse depression behind middle coxae; penis with internal sac long, extending internally far beyond the base.

15(16) Pronotum strongly wrinkled-punctate, depressed on each side of the median carina; aedeagus with penis evenly rounded laterally, widest at basal third, subtriangularly acuminate apically, without hairs at apex; internal sac long, extending internally beyond the middle of struts, gonopore terminal, without sclerite, asperate brown area divided into five regions seen dorsally in repose condition, anterior one paired by ostium, second one transverse, third one visibly paired, fourth one reverse $U$ - or V-

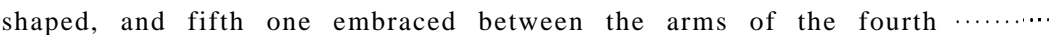

16(15) Pronotum densely punctate; aedeagus with penis flat, widely rounded at apex, ventral surface widely membraneous, with hairs at apical margin ; internal sac not beyond the middle of struts, with a pair of ( )-shaped sclerites at gonopore, innermost part divided into ventral and small dorsal lobes, to the latter ejaculatory duct open

Hylobitelus Reitter

17 (14) Antennal club oval to oblong oval, first segment shorter than the second, seventh segment of funicle free from club; rostrum often with two dorsal furrows; fore tibiae more or less curved internally at apex, outer setose fringe of hind tibiae weakly to strongly oblique; metasternum with transverse depression behind middle coxae; penis with internal sac not extending beyond the base, invisible in repose condition, without a pair of scle-

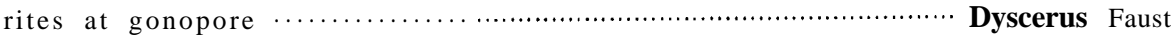

18(1): Elytra without humeral callus; metasternum between middle and hind coxae as long as or shorter than the first ventrite behind coxa.

19(20): Scutellum absent; abdominal process between coxae as wide as the base of hind femur; metepisterna partly covered by elytra; body oblong oval ...

Euthycus Pascoe

20(19): Scutellum evident; abdominal process between coxae more than twice as wide as the base of hind femur; metepisterna entirely visible ; body oval

Kyliparus gen. nov.

\section{Kobuzo Kôno}

Kobuzo Kôno, 1933, Ins. Mats., VIII: 188; Kôno, 1934, Journ.Fac. Agr., Hokkaido Imp. Univ., XXX111 (3) : 225, 240; Morimoto, 1962, Journ.Fac. Agr., Kyushu Univ., 12: 64; Aslam, 1963, Bull. British Mus. (N. H.), Ent., 13(3): 60. Type-species : Hylobius rectirostris Roelofs by original designation). 

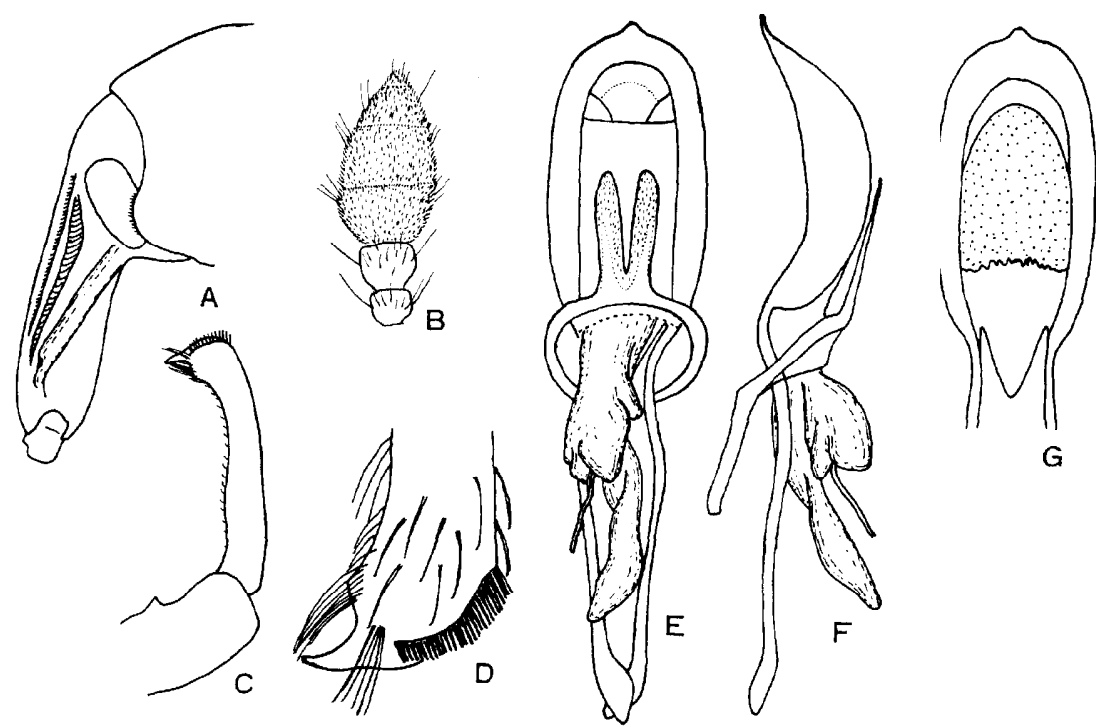

Fig. 1. Kobuzo rectirostris (Roelofs), male. A: Head and rostrum. B : Distal segments of antenna. C : Fore tibia. D : Apex of hind tibia. E : Aedeagus, dorsal. F : Ditto, lateral. $\mathrm{G}:$ Penis, ventral.

\section{Kobuzo rectirostris (Roelofs) (Fig. 1)}

Hylobius rectirostris Roelofs, 1873, Ann. Soc. Ent. Belg., XVI: 188 (Japon).

Kobuzo rectirostris: Kôno, 1933, Ins. Mats., VII: 188; Kôno, 1934, Journ.Fac. Agr., Hokkaido Imp. Univ., XXXIII (3) : 240 (Prov. Kaga) ; Marshall, 1936, Ind. Forest Rec., 1: 207 (comp.w. crassus) ; Iga, 1955, Col. Ill. Ins. Jap., Col.: 140, pl. 50, fig. 42 (Honshu, Shikoku) ; Iga, 1955, Col. Ill. Ins. Jap., Cal., enl. \& rev. ed.,: 198, pl. 62, fig. 1379; Morimoto, 1962, Sci. Bull. Fac. Agr., Kyushu Univ., 19: 395 (Honshu, Kyushu) ; Nakane, 1963, Icon. Ins. Jap. Col. nat. ed., II : 368, pl. 184, fig. 20 (Honshu, Kyushu).

Specimens examined: Mt. Ninooji, Niigata Pref., 1ð, 19. v. 1963, H. Koike leg. Toyohiramachi, Hiroshima Pref., 1§, K. Miyakawa leg. Jinzenji, Kochi City, 1 ð 2 우, 30. viii. 1950, K. Morimoto leg. Mt. Hikosan, Fukuoka Pref., 1 우, 17. iii. 1955, H. Kamiya leg. Hirao, Fukuoka City, 1 ․ , 2. v. 1954, Y. Murakami leg. ; 1 우, 21. iv. 1955, H. Kamiya leg. Nishiyama, Nagasaki City, 1 우, 13. vii. 1954, K. Asakura leg. Tatsudayama, Kumamoto City, 1ㅇ,v. 1972, Z. Kuranaga leg. Tomioka, Amakusa, Kumamoto Pref., 1우, 25. vi. 1931, Esaki and Hori leg.

DistRIBUTION : Japan (Honshu, Shikoku, Kyushu).

One female was bred from fruit of Castanopsis cuspidata.

\section{Aclees Schoenherr}

Aclees Schoenherr, 1836, Gen. Sp. Curc., III: 238; Schoenherr, 1843, Gen. Sp. Curc., VII (2): 120; Castelnau, 1840, Hist. Nat. Ins., Col. II: 334; Lacordaire, 1863, Gen. Col. VI: 450,

455; Faust, 1892, Stett. Etn. Zeit., LIII: 195; Hustache, 1924, Buli. Acad. Malgasche, 
(n. s.) VII : 210 ;Kôno, 1934, Journ.Fac. Agr., Hokkaido Imp. Univ., XXX111 (3) : 225; Voss, 1958, Decheniana, Beihefte 5: 43; Morimoto, 1962, Journ.Fac. Agr., Kyushu Univ., 12 (1) : 63; Aslam, 1963, Bull. British Mus. (N. H.), Ent. 13 (3) : 63. Typespecies : Aclees cribratus Gyllenhal, by original designation.

\section{Aclees hirayamai Kôno (Figs. 2, 3)}

Aclees hirayamai Kôno, 1933, Ins. Mats., VII: 183 (Iriomote, Formosa) ; Kôno, 1934, Journ. Fac. Agr., Hokkaido Imp. Univ., XXXIII (3) : 226, Taf. V, f. 22 (Iriomote, Formosa) ; Voss, 1958, Decheniana, Beihefte 5: 43 (China : Fukien) ; Nakane, 1963, Icon. Ins. Jap. Col. nat. ed., II: 367, pl. 184, fig. 3 (Tokara, Ryukyus, Taiwan).

Specimens eXamined : Is. Hachijo, $70^{\Uparrow} 4$ 우, xi. 1976. Mt. Miyanoura, Is.

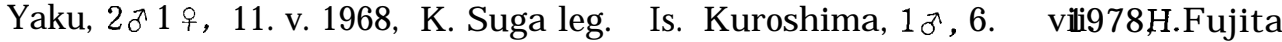
leg. Is. Kuchinoshima, Tokaras, 1 i , 26. vi. 1969, H. Makihara leg. Is. Nakanoshima. Tokaras, $1 \delta^{\star}, 30$. v. 1962, M. Sato leg. Mt. Yuwan. Amami-Oshima,

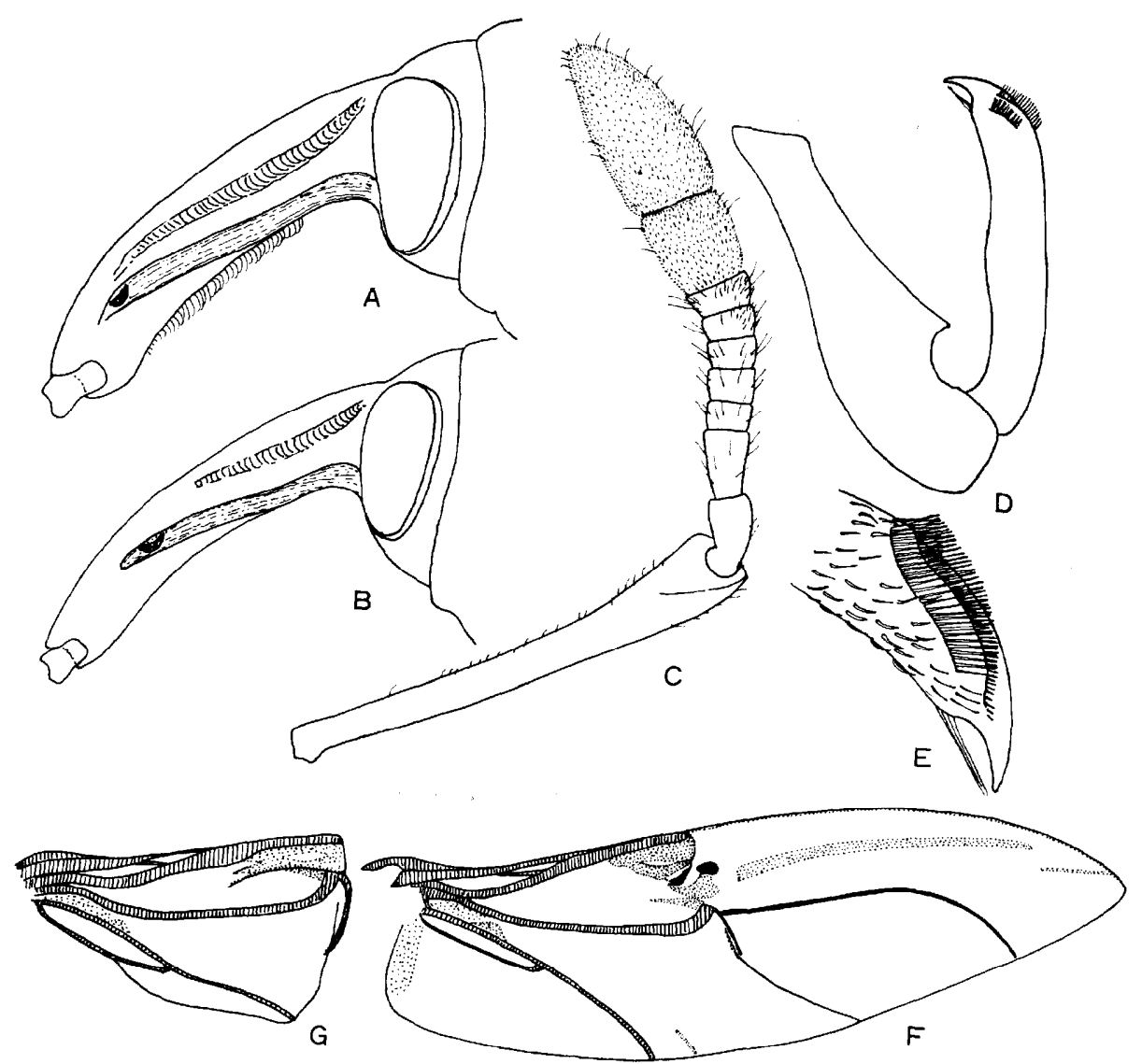

Fig. 2. Aclees hirayamai Kôno. A : Head and rostrum, male. B : Ditto, female. C : Antenna. D : Fore leg. E : Apex of hind tibia. F: Hind wing. G : Ditto, in fold. 

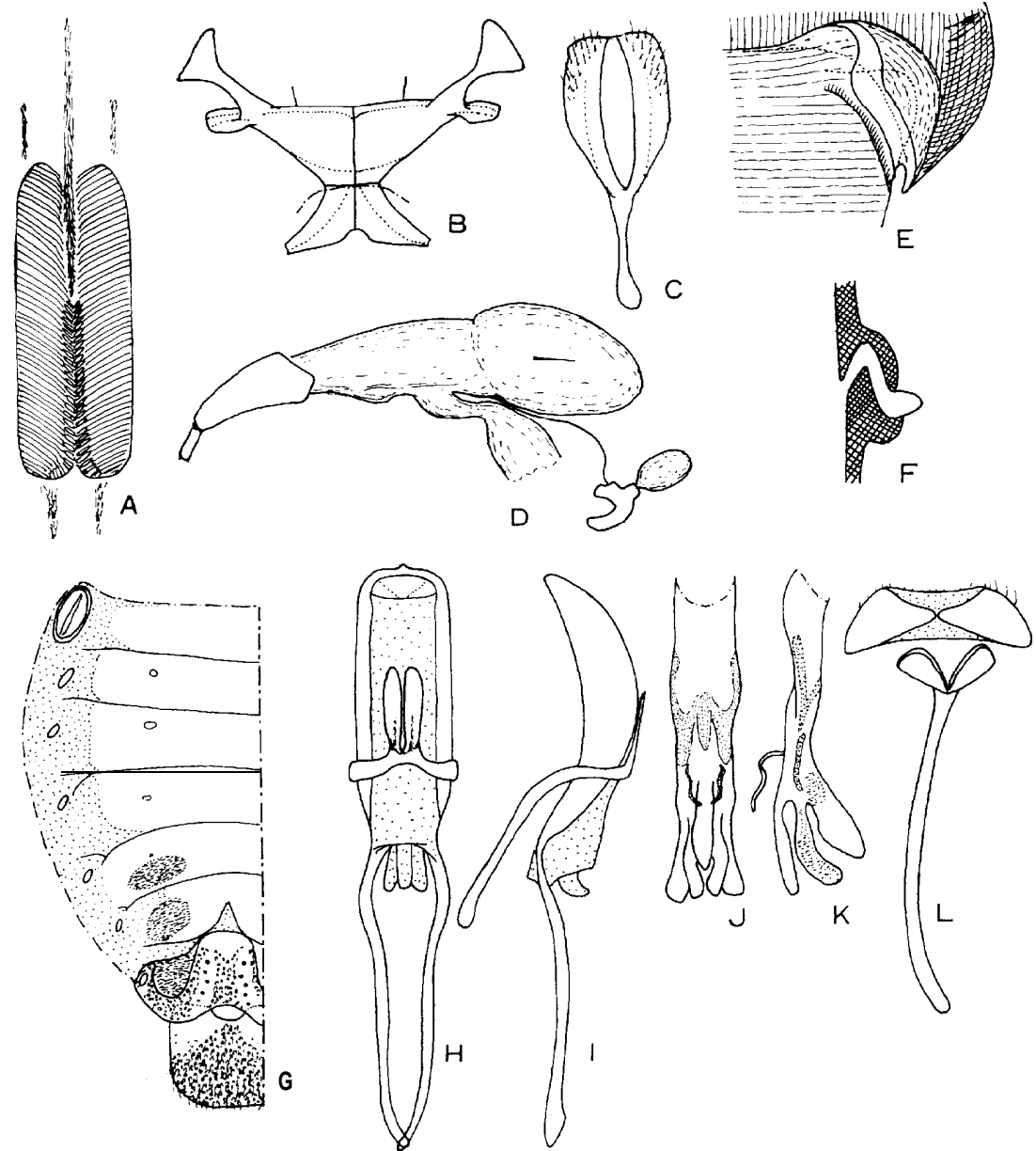

Fig. 3. Aclees hirayamai Kôno. A : Proventriculus. B : Metendosternite. C : Female eighth sternite. D : Female genital organ, lateral. E: Lateral hinge of first and second ventrites, internal. F : Ditto, cross-section. G : Male tergites. H : Aedeagus, dorsal. I : Ditto, lateral. J : Internal sac, dorsal. K : Ditto, lateral. L : Male ninth sternite.

1 우, 23. viii. 1960, Y. Komiya leg. Nase, Amami-Oshima, 1 § 1 , 10. vi. 1973, K. Kawabata leg. Naha, Okinawa, 1우, 10. vi. 1962, K. Kojima leg. ;1ð, 17. ix. 1979, S. Kuniyoshi leg. Shuri, Okinawa, 1 우, 20. x. 1959, S. Kuniyoshi leg. ; 1 ㅇ, 8. iv. 1960, S. Kuniyoshi leg. ; $10^{\top} 1$ ㅇ, 14. v. 1962, M. Kina leg. Kijota, Okinawa, 1ð, 20. v. 1961, 0. Nakachi leg. Tamagusuku, Okinawa, 1, 16. iii. 1962, M. Kina leg. Kudeken, Okinawa, 1ð, 22. iv. 1975, H. Irie leg. Chibana, Okinawa, 2ð, 21. v. 1980, M. Yamauchi leg. Nago, Okinawa, 1우 13. viii. 1980, A. Seino leg. Bannadake, Ishigaki, 2 우, 7-9. ix. 1969, H. Makihara leg. ; 4 § 3 우, 1. iv. 1974, 0. Yamaji leg.; $2 \gtrsim 5$ 우, 13-14. vi. 1974, T. Mikage leg. Mt. Omoto- 
dake, Ishigaki, $1 \succsim$, 18. vii. 1963, T. Nagayoshi leg. ;1ð, 16. iii. 1964, Y. Miyatake leg. ; 16, 11. vi. 1974, T. Mikage leg. Ohara, Ishigaki, 1ठ, 9. viii. 1962, M. Chûjô leg. Toro-gawa, Ishigaki, 2ð, 17. iii. 1964, Y. Miyatake leg. Suigenchi, Ishigaki, 1우, 10. vii. 1963, T. Nagayoshi leg. Ishigaki, $20^{\Uparrow} 2$ 우, 20. viii. 1968, T. Takara leg. ; $1 \precsim, 20$. v. 1962, K. Kojima leg. Mt. Ushiku, Iriomote, 1 우, 3. ix. 1963, G. A. Samuelson leg. Kuira, Iriomote, 1, 18. vi. 1974, T. Mikage leg. Higawa, Yonaguni, $1 \jmath^{\top}$ 우, 12. vii. 1976, S. Kimoto leg. Mt. Shitoushan, Miaoli Hsien. Taiwan, 1 \& , 24-26. v. 1980, H. Makihara leg. Hungtou, Lan Hse, Taitung Hsien, Taiwan, 1 우, 4-6. vi. 1980, H. Makihara leg. Musha, Taiwan, 1 우, v-viii. 1960. Kotosho, nr. Formosa, 2ð, 8. viii. 1968, H. Makihara leg.

Distribution : Japan (Is. Hachijo (imported and established), Kuroshima, Kuchinoshima, Nakanoshima, Amami-Oshima, Okinawa, Ishigaki, Iriomote and Yonaguni Isls.), Taiwan, China.

Biological note. The larvae feed on Ficus erecta and F. elastica. The latter is cultivated as an ornamental tree and often seriously damaged in some nurseries by this weevils. The adults are attracted by light. In Is. Hachijo, this species is imported from the Ryukyus with the sapling of Ficus elastica.

\section{KEY TO THE RELATED SPECIES}

1(2): Forehead between eyes, basal half of rostrum, basal margin of pronotum and suture of elytra densely clothed with yellowish setae, the other intervals of elytra each with two or three irregular rows of similar setae; pronotum strongly punctate and weakly wrinkled, the punctures becoming smaller and finer to the dorso-anterior area. Micronesia (Saipan, Yap, Peliliou and Palau) .........................................ees saipanensis Kôno

2(1): Derm at most with fine steae.

3(4): Metasternum sparsely punctate and often finely wrinkled; pronotum punctate and weakly wrinkled at basal and lateral areas, the punctures smaller and derm smoother on the dorsal area before the middle, and finely punctate at anterior margin. Japan, Taiwan, China (Fukien)

Aclees hirayamai Kôno

4(3): Metasternum smooth with fine scattered punctures ; pronotum wrinkled punctate excepting the anterior margin.

5(6): Pronotum strongly wrinkled-punctate, with a weak median oblong glossy callus before the middle; third and fourth ventrites as smooth as two precedings and metasternum, with large punctures at sides. Taiwan, China (Fukien)

Aclees taiwanensis Kôno

6(5): Pronotum less strongly wrinkled-punctate, median callus indistinct or absent; third and fourth ventrites as in taiwanensis, but with several larger punctures between the middle and sides. China, Burma, Java, Borneo $\ldots$

Aclees cribratus Gyllenhal

\section{Hylobitelus Reitter}

Hylobitelus Reitter, 1923, Wien. Ent. Zschr., XL: 24 (as a subgenus of Hylobius).

Type-species : Hylobius verrucipennis, by monotypy.

Poiyaunbus Kôno, 1934, Journ.Fac. Agr., Hokkaido Imp. Univ., XXX111 (3) : 241; 
Morimoto, 1962, Journ.Fac. Agr., Kyushu Univ., 12: 64. Type-species: Hylo-

bius gebleri Boheman, by original designation. Syn. nov.

Hylobius auct. (partim). (abietis group of Wood, 1957, Canad. Ent., LXXXIX: 38).

Hylobitelus and Poiyaunbus are named for the brachypterous species of this genus, and $H$. verrucipennis is similar to gebleri.

$$
\text { Key to SPECIES OF THE GenUs Hylobitelus IN JAPAN }
$$

1(4): Bare depression of metasternum much longer than wide.

2(3): Pronotum densely and confluently punctate; elytra slightly rounded at sides and widest in the middle; fore tibiae with inner expansion wider; penis more flat .................................... Hylobitelus futabae sp. nov.

3(2): Pronotum rather reticulately punctate in the median area; elytrs parallelsided in basal half; fore tibiae with inner expansion narrower ; penis

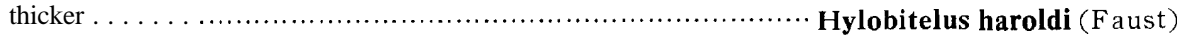

4(1): Bare depression of metasternum much wider than long.

5(6): Ventrites with dense yellowish scales at sides; elytra parallel-sided in basal half; scutellum a little longer than wide ; penis gradually narrowing apically and shortly pointed at apex, rather strongly curved ventrad at

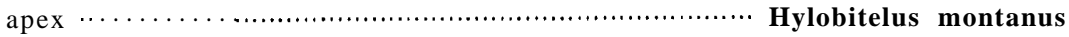

6(5): Ventrites with sparse setiform scales; elytra widest at the middle, the sides more or less rounded; scutellum at least as wide as long; penis not sharply bent at apex.

$7(8)$ : Body length 11-14 mm. (excl. rostrum); black, with white small spots on elytra Hylobitelus gebleri (Boheman)

$8(7)$ : Body length $8-9 \mathrm{~mm}$.

9(10): Hind tibiae dilated distally; penis with long hairs at apex, widest at apical third, then straightly narrowing apically for a short distance and rounded at tip, membraneous part of parameres continuous to each other around the notch

Hylobitelus shiroumaensis sp. nov.

10(9): Hind tibiae hardly dilated distally; penis rounded near apex and almost truncate at tip, membraneous part of parameres interrupted in the middle at the notch

Hylobitelus pinastri (Gyllenhal)

\section{Hylobitelus haroldi (Faust) comb. nov. (Fig. 4)}

Hylobius abietis var. Roelofs, 1873, Ann. Soc. Ent. Belg., XVI : 187 (Japon).

Curculio abietis: Lewis, 1879, Cat. Col. Jap. Archip., 22.

Curculio (Hylobius) abietis : Harold, 1878, Deut. Ent. Zeit., XXII: 83 (Hagi).

Hylobius abietis: Schoenfeldt, 1887, Cat. Col. Jap.: 144 (Hiogo, Hagi); Niijima, 1913, Forest Ent. : 102 ; Matsumura, 1915, Konchu Bunruigaku, II: 98; Matsumura, 1915, Dainippon Gaichu Zensho, II: 211, pl. XXII, fig. 13; Niijima, 1923, Forest Protect. (new ed.) I: 200 (Biology, control) ; Okamoto, 1924, Ins. Fauna of Querpart Isl.: 184.

Hylobius Haroldi Faust, 1882, Deut. Ent. Zeit., XXVI: 273 (Amur) ; Faust, 1887, Horae Soc. Ent. Ross., XXI: 28 (Korea) ; Yokoyama, 1931, Zoku Nippon no Kochu: 59, pl. VII, f. g.

Hylobius haroldi: Matsumura, 1931, 6000 Ill. Ins. Jap. : 285; Matsumura, 1931, Ill. Common Ins. Jap., III: 113, pl. XXVI, f. 13; Kamiya \& Adachi, 1933, Genshoku KochuZufu, pl. 143, f. 10; Egorov, 1977, in Kryzhanovskii \&Galkin, Syst. Faun. Ins. (Akad. Nauk. SSSR) : 35 (East Siberia).

Hylobius abietis haroldi: Zumpt, 1932, Kol. Rdsch., XVIII: 131; Kôno, 1934, Journ.Fac. Agr., Hokkaido Imp. Univ., XXX111 (3) : 230 (Honshu, Shikoku, Kyushu, Korea) ; Kôno\& 


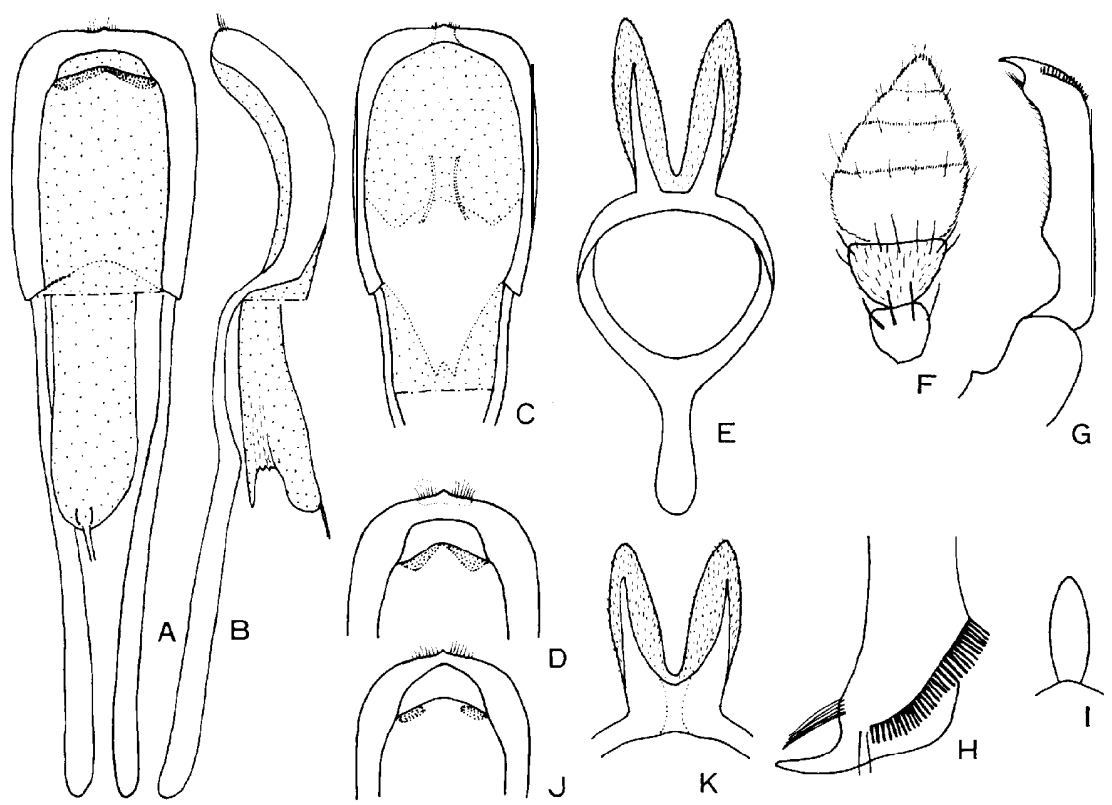

Fig. 4. A- I : Hylobitelus haroldi (Faust) and J, K : abietis (Linnaeus). A : Penis, dorsal. B : Ditto, lateral. C : Ditto, ventral. D : Apex of penis. E: Tegmen and parameres. F : Distal segments of antenna. G : Fore leg. H : Apex of hind tibia. I : Bare depression on metasternum. J : Apex of penis. K: Parameres.

Kim, 1937, Journ. Chosen Nat. Hist. Soc., (22) : 21; Kôno, 1950, Icon. Ins. Jap., (rev. ed.) : 1265, fig. 3645; Iga, 1955, Col. Ill. Ins. Jap., Col. 220, fig. 1567; Shimoshima, 1958, Nagano Rinyu (Jan.): 1-6 (Injury, control); Kondo, 1963, Shinrin Boeki news, 12 (3) : 54-56 (Injury) ; Nakane, 1963, Icon. Ins. Jap. Col. nat. ed., II: 367, p1. 184, fig. 5; Motokurumada \& Morimoto, 1977, Rep. Forest Soc. Kyushu Br., (30) : 269 (Injury) ; Chao \& Chen, 1981. Econ. Ins. Fauna China, 20: 139, pl. XI, fig. 119 (China).

Specimens examined : 120 specimens from Fukushima, Niigata, Tochigi, Nagano, Shizuoka, Kyoto, Osaka, Okayama, Kochi, Fukuoka, Nagasaki, Kumamoto and Kagoshima Prefs., and Korea.

Distribution: Japan (Honshu, Shikoku, Kyushu), Korea, East Siberia, China.

Host trees: The stump of Pinus spp. Adults feed on the young trees and small branches of Pinus spp., Cryptomeria japonica and Larix kaempferi, and often injurious to these trees at the afforested lands.

Hylobius haroldi has been treated as a subspecies of abietis since Zumpt, 1932. But they are as different as the other related species in the following characters.

abietis: Pronotum with punctures more or less longitudinally confluent ; elytra with striae less strongly punctate, intervals smoother; pro- and mesosternal processes densely covered with yellowish long hairy scales ; penis with marginal sclerite narrowed at apex, parameres with sclerotized basal area thicker; body robust, scales yellowish. 


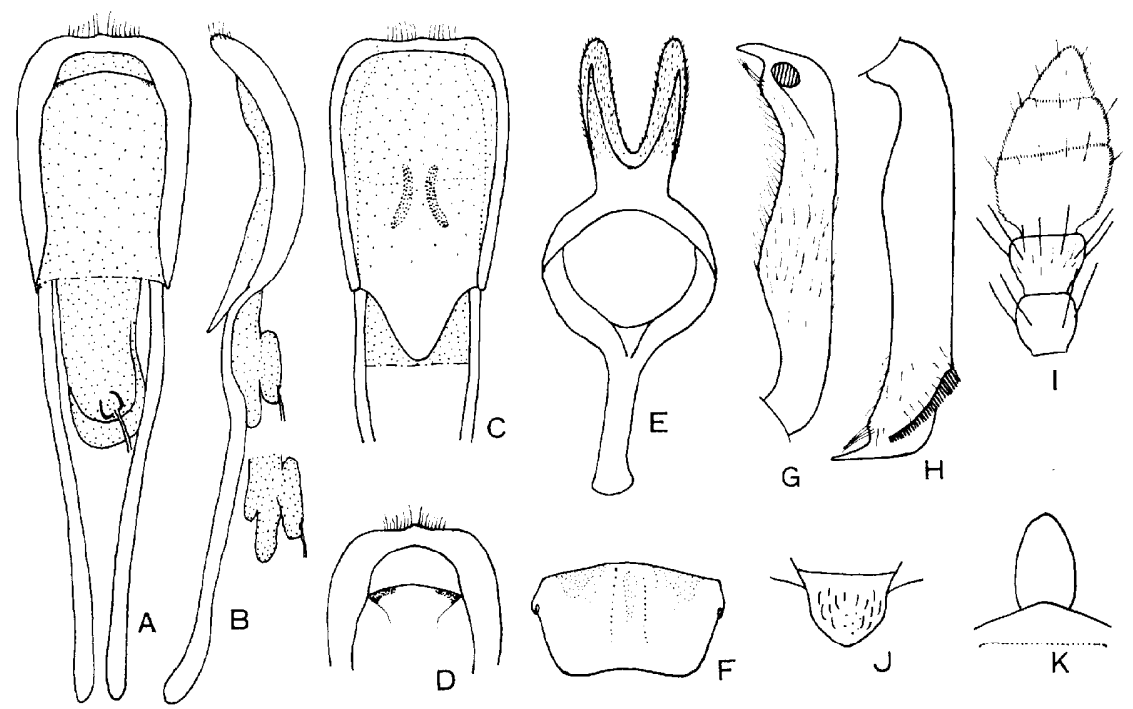

Fig. 5. Hylobitelus futabae sp. nov., male. A : Penis, dorsal. B : Ditto, lateral. C : Ditto, ventral D : Apex of penis. E : Tegmen and parameres. F : Eighth tergite. G : Fore tibiae. H:Hind tibia. I : Distal segments of antenna. J: Scutellum. K: Bare depression of metasternum.

haroldi: Pronotum with punctures reticulate in the median area ; elytra with striae strongly punctate, intervals slightly uneven; pro- and mesosternal processes with sparse greyish setiferous scales as on the other part of sterna; penis with marginal sclerite of the same width at apex; parameres with sclerotized parts separately attached to basal ring; body slenderer, scales yellowish brown.

Hylobitelus futabae sp. nov. (Figs. $5 ; 46 \mathrm{~B}$ )

Male. Derm black with some reddish tinge, antennae and tarsi dark reddish brown, apices of tibiae often dark reddish brown; pronotum with sparse ochreous setiform scales, which being a little denser before scutellum; elytra with ill-defined bands of similar scales, the anterior band flat V-shaped between fourth intervals at $1 / 4$ from base, the second band running obliquely from side margin at $1 / 4$ from base to the middle of suture, inner part often vague, the third band transverse or slightly oblique and usually present on fifth to ninth intervals, the fourth band transverse or weakly sinuate in entire breadth at $1 / 4$ from apex, the other area with sparse scales of the similar shape ; legs and underside with sparse yellowish grey setiform scales, which being much narrower than dorsal one, the scales denser on each side of ventrites.

Head with small dense punctures; forehead between eyes $3 / 4$ the width of the base of rostrum, with a small shallow fovea. Rostrum much shorter 
than pronotum $(5: 6)$, almost parallei-sided to the middle, gradually widening anteriorly thence to the antennae, dorsum with rather rugose punctures, which longitudinally confluent leaving one or two weak fine carinae on each side, median carina absent or at most present in the middle, apical area bare, longitudinally wrinkled-punctate. Antennae with second segment of funicle $2 / 3$ times as long as the first and 1.5 times as long as the third, third to sixth segments of funicle moniliform, seventh segment a little wider than long, club compact, first segment twice as long as the second.

Pronotum as long as wide, rounded laterally, widest at the middle, slightly constricted at apex ; disk with large confluent punctures, which becoming smaller towards apex, the interstices often convex and glossy, median carina short.

Scutellum sparsely punctulate, with setiferous greyish scales.

Elytra very slightly rounded and dilated to the middle, conjoint apex sharply notched at suture, striae with regular large punctures, which becoming smaller behind declivity, intervals almost as wide as striae, weakly convex, irregularly with low granules, third interval slightly higher than the others, especially near the base.

Legs with femora dentate, tibiae rather strongly dilated internally at $1 / 3$ from base.

Metasternum with large punctures, median bare depression much longer than wide. Fifth ventrite flattened in the middle, with dense yellowish hairs excepting the basal margin ; seventh tergite with antero-lateral unsclerotized area less developed. Penis flat, weakly curved, with small triangular weak point at apex.

Female. First and second ventrites not depressed in the middle.

Length : 8. 4-10.5 mm (excl. rostrum).

Holotype ơ (Type No. 2362, Kyushu Univ.), Mt. Tateshinayama (7-gome, (1900 m), Nagano Pref ., 30. vi. 1971, R. \& F. Ishikawa leg.

Paratypes: Sugenuma, Gunma Pref ., 10, 10. vii. 1975, H. Irie leg. Same data as holotype, $3 \delta$. Mt. Tateshinayama (Shibunoyu, $1900 \mathrm{~m}$ ), Nagano Pref ., $1{ }^{\star}, 29$. vi. 1971, R. \& F. Ishikawa leg. Mt. Tateshinayama (Kasuga Bokujo), Nagano Pref ., 1우, 1. vii. 1971, R. \& F. Ishikawa leg. Mugikusa-toge, Tateshina, Nagano Pref ., $1 \gtrsim$, 10. viii. 1974, K. Unno leg. Kamikochi, Nagano Pref., 1ठ, 22. vii. 1917, T. Esaki leg.

Distribution: Japan (Honshu :Gunma and Nagano Prefs.).

This new species is very close to haroldi, but the elytra are not parallelsided, but slightly rounded with drooping shoulders, the four scaly bands are wider, the pronotum is more densely and confluently punctate, and the penis is more flat and wider. 

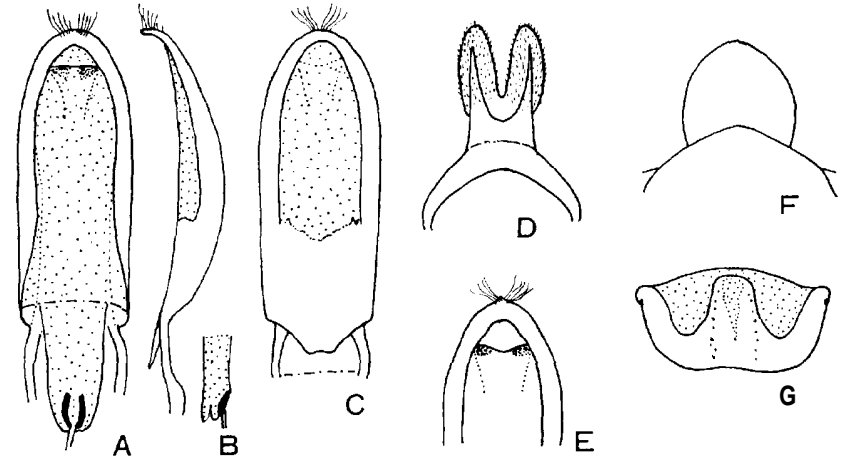

Fig. 6. Hylobitelus montanus (Kôno), male. A : Penis, dorsal. B : Ditto, lateral. C : Ditto, ventral. D : Parameres. E: Apex of penis. F: Bare depression of metasternum. G : Eighth tergite.

Hylobitelus montanus (Kôno), comb. nov. (Fig. 6)

Hylobius montanus Kôno, 1934, Journ.Fac. Agr., Hokkaido Imp. Univ., XXX111 (3) : 231

(Hokkaido: Mt. Daisetsu, Shikaribetsu, Teshio and Sounkei) ;Kôno, 1936, Biogeogr.,

1(2) : 98; Nakane, 1963, Icon. Ins. Jap. Col. nat. ed., II: 367, pl. 184, fig. 6 (Hokkaido, Sakhalin).

Specimens examined : Aizankei, Mt. Daisetsu, Hokkaido, $1 \delta^{\Uparrow} 3$ 우, 29. vii. 1955, K. Morimoto leg. ; $1 \sigma^{\star}, 19$. vii. 1962, Y. Miyatake leg. Kumanotaira, Mt. Daisetsu, Hokkaido, 1 우, 22. vii. 1962, T. Saigusa leg. Antaroma, Hokkaido, $1 \precsim 2$ 우, 21-25. vii. 1962, Y. Miyatake leg. Nukabira, Tokachi, Hokkaido, $1 \delta^{\Uparrow}, 21$. vii. 1959, K. Morimoto leg. Piuka, Teshio, Hokkaido, 1 우, 22. vii. 1952, T. Shirôzu leg. Jushichinosawa, Mt. Nipesotsu, Hokkaido, 1ð, 6. viii. 1976, H. Irie leg. Chuzenji, Nikko, Tochigi Pref., $1 \delta^{\star}, 8$. vii. 1975, H. Irie leg. Sugenuma, Gunma Pref., 1우, 12. vii. 1952, Y. Kato leg.;3 32 우, 10-11. vii. 1975, A. Karasawa leg. Mt. Nyugasa, Nagano Pref., $1 \succsim 4$ 우, 20-21. vi. 1962, K. Oshima leg. Mt. Ontake, Gifu Pref., $1 \delta^{\star} 1$ ㅇ, 30. vii. 1963, T. Nohira leg. Hirayu, Gifu Pref., 1 우, 19. vi. 1963, T. Nohira leg.

Distribution : Japan (Hokkaido, Honshu), Sakhalin.

Host trees : Pinus pumila, Abies sachalinensis, Picea jezoensis.

Hylobitelus pinastri (Gyllenhal), comb. nov. (Fig. 7)

Rhynchaenus pinastri Gyllenhal, 1813, Ins. Suec., I, 3: 168 (Suecia).

Hylobius pinastri : Schoenherr, 1935, Gen. Sp. Curec., II: 335 (Suecia).

Hylobius abietis: Matsumura (nec Linné), 1911, Journ. Coll. Agr., Tohoku Imp. Univ., IV: 130 (Saghalin).

Hylobius pinastri karafutonis Kôno, 1934, Journ.Fac. Agr., Hokkaido Imp. Univ., XXX111 (3): 231 (Saghalin, Hokkaido) ; Kôno, 1936, Biogeogr., I (2) : 98 (Berg. Daisetsu) ; Nakane, 1963, Icon. Ins. Jap. Col. nat. ed., II: 367, pl. 184, fig. 7. Syn. nov.

Hylobius pinastri montivagus Nakane, 1964, Sci. Rep. Kyoto Pref. Univ., 15 A : 37 (Mt. Jonen). Syn. nov.

Specimens examined : Aizankei, Mt. Daisetsu, Hokkaido, $2 \precsim 4$ 우, 27-29. vii. 

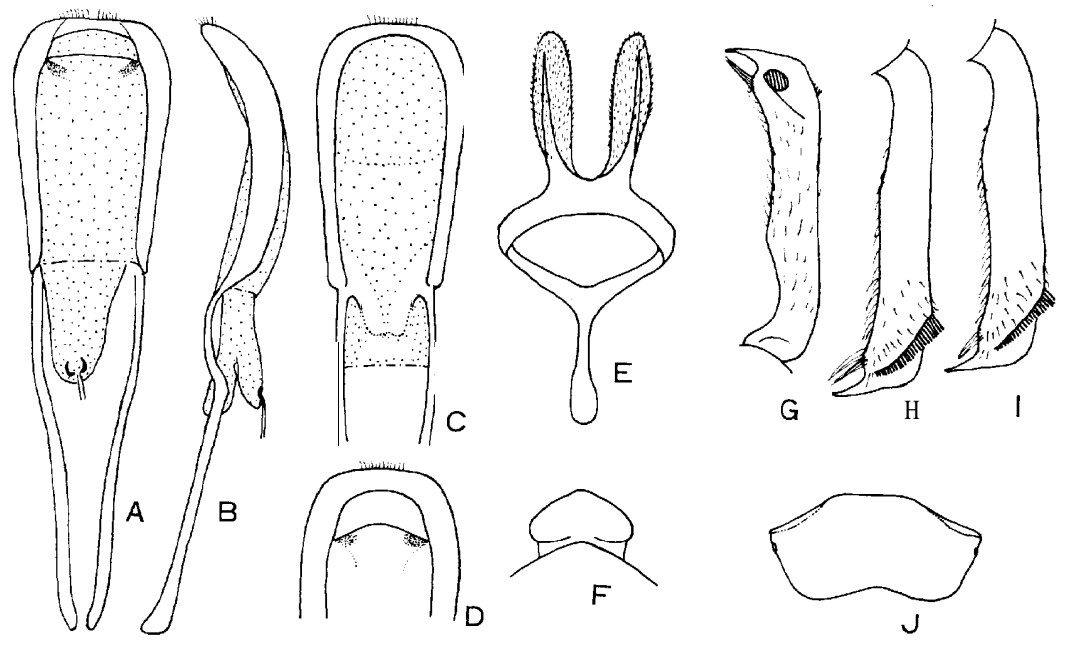

Fig. 7. Hylobitelus pinastri (Gyllenhal), male from Hokkaido. A : Penis, dorsal. B : Ditto, lateral. C : Ditto, ventral. D : Apex of penis. E : Tegmen and parameres. F : Bare depression of metasternum. G : Fore tibia. H, I : Hind tibia. J : Eighth tergite.

1955, K. Morimoto leg. Jushichinosawa, Mt. Nipesotsu, Hokkaido, 1ð, 6. viii. 1976, H. Irie leg. Nukabira, Tokachi, Hokkaido, 3 ð 1 우, 21-23. vii. 1959, K. Morimoto leg. Nikamatazawa, Mt. Shirane, Gunma Pref., 1 우, 16. vii. 1975, H. Irie leg. Mt. Kitadake, Yamanashi Pref., 1ㅇ, 2. viii. 1962, J. Koyama leg. Mt. Kongo, Corea,1우, 17. viii. 1940, T. Shirôzu leg. Riesengebirge, Deutschland, 1 우.

Distriburton : Europe, Siberia, Sakhalin, Korea, Japan (Hokkaido, Honshu). Host тregs: Ahies sachalinensis, Picea jezoensis, Pinus pumila.

Kôno (1934) distinguished the subspecies karafufonis from the nominate population on the following points: "Halsschild dichter und gröber punktiert. Die Punkte in den Punktreihen der Fliigeldecken gröber. Schilddhen halbkreis. förmig”, and Nakane (1964) described a subspecies, montivagus, on these characters as "Two examples differ from Kono's form in having smaller body size $(7 \mathrm{~mm}$ ), more clearly reddish colouration, relatively wider elytra (about a half longer than wide) with less parallel and a little more rounded sides, and more roughly punctured pronotum". Those characters are, however, considerably variable and montivagus is apparently named for the smaller individuals. One female from Germany before me is an individual within the range of variation of Japanese population.

\section{Hylobitelus shiroumuensis sp. nov. (Fig. 8)}

Male. Dull black, apices of tibiae, tarsi and antennae dark reddish brown; pronotum with sparse yellowish grey setiform scales forming the antero-latera!, latero-median and antescutellar ill-defined patches; elytra with two bands, 


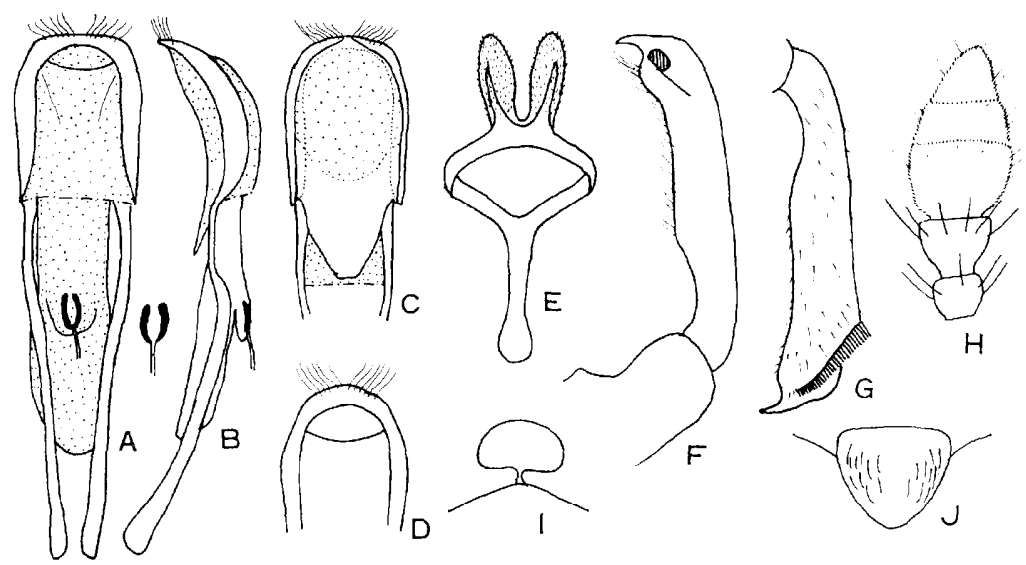

Fig. 8. Hylobitelus shiroumaensis sp. nov., male. A : Penis, dorsal. B : Ditto, lateral. C: Ditto, ventral. D : Apex of penis. E: Tegmen and parameres. F : Fore tibia. G : Hind tibia. H: Distal segments of antenna. I : Bare depression of metasternum. $\mathrm{J}:$ Scutellum.

the anterior one oblique from side margin at $1 / 3$ from base to the middle of suture, the other transverse in entire breadth at $1 / 4$ from apex, second interval with a small scaly patch at basal $1 / 4$, third to fifth intervals with conjoint scaly patches at declivity. Underside with sparse greyish small setiform scales.

Head with small dense punctures; forehead between eyes $3 / 4$ the width of rostrum at base, with a small median fovea. Rostrum as long as pronoturn, almost parallel-sided to the middle, then weakly dilated distally to the antennae ; dorsum with dense punctures and five narrow carinae. Antennae with second segment of funicle half as long as first and 1.5 times as long as the third, third to sixth segments subequal in shape, seventh segment transverse, club compact, first segment twice as long as the second.

Pronotum a little wider than long $(11: 10)$, the sides rounded before the middle, straightly and weakly narrowing thence posteriorly, widest at $1 / 3$ from apex, disk densely punctate, the punctures confluent at sides and the interstices reticulate in the median area, median carina short, $1 / 3$ the length of pronotum.

Scutellum subcordiform, sparsely punctulate and scaled.

Elytra weakly rounded at sides, widest at the middle, conjoint apex weakly notched at the suture, striae with regular oblong clear-cut punctures, which becoming smaller behind declivity, intervals flat, about as wide as striae, indistinctly wrinkled granulate, third interval a little wider.

Femora dentate; middle and hind tibiae weakly dilated apically.

Metasternum with large punctures, median bare depression transverse with round sides. Penis flat, widest at apical third, then straightly narrowing 
apically for a short distance and rounded at apex, with rather long hairs along apical margin, sclerites of gonopore large and long.

Female. Unknown.

Length : $8.0 \mathrm{~mm}$. (excl. rostrum).

Holotype ठౌ (Type No. 2363, Kyushu Univ.), Mt. Shiroumadake (near summit), Nagano Pref., 22. vii. 1961, K. Morimoto leg.

Distribution : Japan (Nagano Pref .).

This is close to pinastri, but the hind tibiae are dialted distally and the aedeagus is different.

Hylobitelus gebleri (Boheman), comb. nov. (Fig. 9)

Hylobius Gebleri Boheman, 1834, in Schoenh., Gen. Sp. Cur-c., II: 338 (Siberia); Schoenherr, 1840, Gen. Sp. Cure., VI (2): 300 (Siberia); Roelofs, 1875, Compt. Rend. Soc. Ent. Belg., XVIII: cxxx (Yesso); Faust, 1882, Deut. Ent. Zeit., XXVI: 274 (=signatipennis Roelofs; Ussuri).

Curculio Gebleri: Lewis, 1879, Cat. Col. Jap. Archip.: 22.

Hylobius gebleri : Matsumura, 1931, Ill. Common Ins. Jap., III: 113, 163, pl. XXVI, fig. 12 (Hokkaido, Honshu, Siberia) ; Kuribolutskaya et al., 1978, Trud. Biol. Potsch. Inst., (n. s.), 50 (153) : 94 (Sakhalin).

Hylobius signatipennis Roelofs, 1873, Ann. Soc. Ent. Belg., XVI: 187 (Hakodadi).

Poiyaunbus gebleri : Kôno, 1934, Journ.Fac. Agr., Hokkaido Imp. Univ., XXXIII (3) : 241 , Taf. V, fig. 9 (Hokkaido, Honshu, Siberia) ;Kôno, 1935, Ins. Mats., X: 58 (Is, Kunashiri, Sachalin) ; Kôno, 1936, Biogeogr., 1: 98 (Berg. Daisetsu) : Nakane, 1963, Icon. Ins. Jap. Col. nat. ed., II: 368, pl. 184, fig. 17 (Hokkaido, Honshu, Siberia) ; Kuwayama, 1967, Ins. Fauna South Kuril Isls. : 169 (Kunashiri).

Specimens examined: 34 examples from Hokkaido (Is. Rishiri, Wakkanai, Mt. Daisetsu, Shikaribetsu) and Nagano (Mt. Shiroumadake).

Distribution : Japan (Hokkaido, Honshu), Sakhalin, South Kuril Isls., Siberia.

\section{Hylobius Germar}

Hylobius Germar, 1817, Mag. Ent., 2: 340. Type-species : Rhynchaenus pineti Fabr. = piceus DeGeer, see discussion by Wood, 1957.

Hypomolyx Leconte, 1876, Proc. Amer. Phil. Soc., 15: 139. Type-species: Hylobius pinicola Couper, by monotypy.

Rostrum with dense punctures and deep lateral sulci above antenna1 scrobes. Antennae with seventh segment of funicle dilated distally, club compact, first segment as long as the second. Pronotum wrinkled-punctate, depressed on each side of the median carina. Elytra with regular punctured striae, intervals flat, wrinkled-punctate and/or weakly granulate. Fore tibiae straight externally, weakly dilated internally at basal third; hind tibiae with outer setose fringe of tarsal groove oblique and weakly ascended. Metasternum without postcoxal depression along anterior margin. Aedeagus with penis evenly rounded laterally, widest at basal third, subtriangularly acuminate at apex; internal sac long. extending internally beyond the middle of struts, 


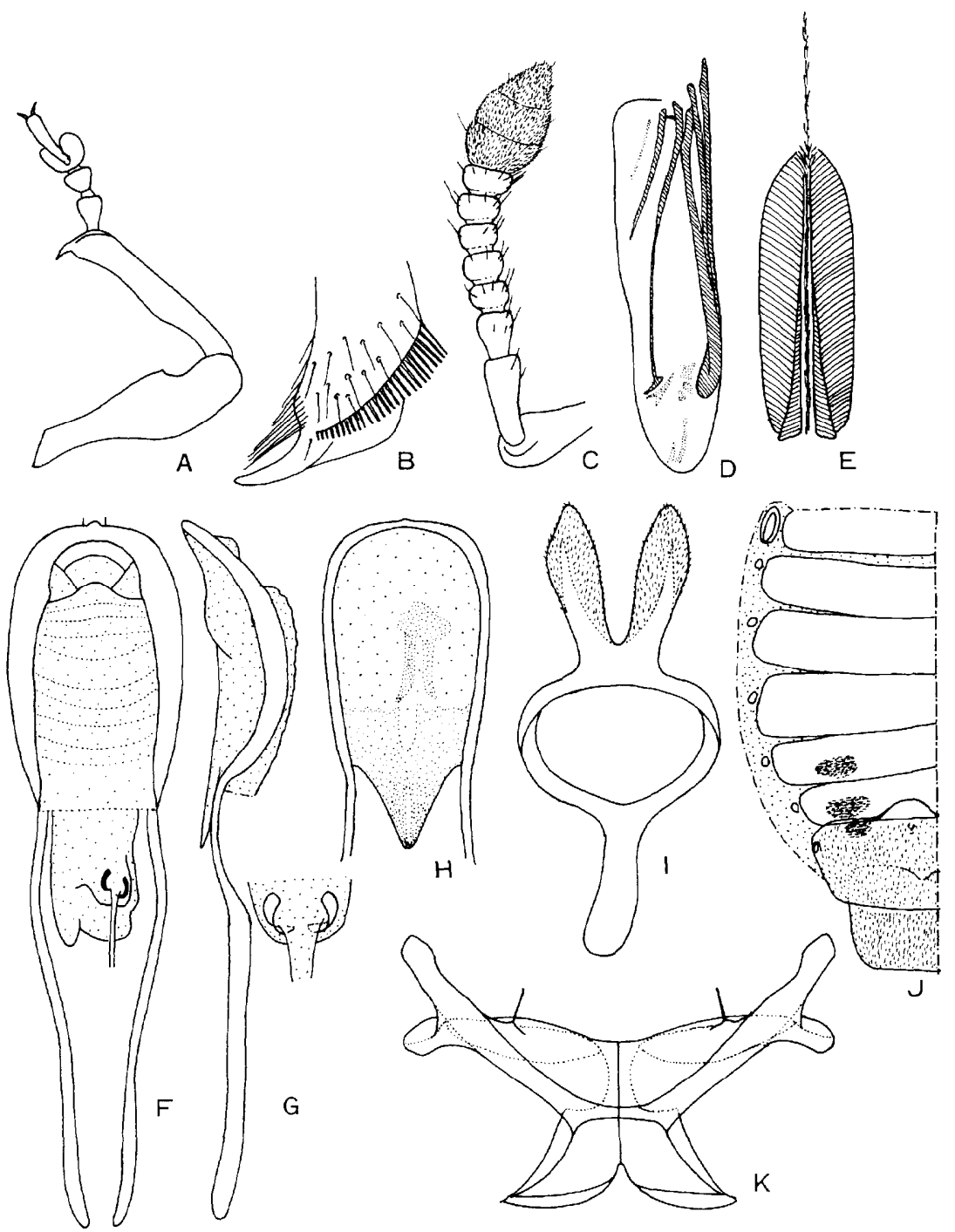

Fig. 9. Hylobitelus gebleri (Boheman), male. A : Fore leg. B : Apex of hind tibia. C:Antenna. D: Hind wing. E : Proventriculus. F: Penis, dorsal. G: Ditto, lateral. H : Ditto, ventral. I : Tegmen and parameres. J: Tergites. K: Metendosternite.

gonopore terminal, without sclerite, internal sac with brownish asperities, asperate area divided into five regions seen dorsally in repose condition, anterior one paired by ostium, second one transverse, third one visibly paired, fourth one reverse U- or V-shaped, and fifth one embraced between the arms of the fourth.

This genus contains very similar species from the Holarctic region, albosparsus (Boheman) form eastern Siberia to Sakhalin, piceus (DeGeer) from 
central and northern Europe to Siberia, ezoensis sp. nov. from Hokkaido, adachii Kôno from central Honshu, pinicola Couper and warreni Wood, both from Canada and north-eastern U.S.A., among which adachii. ezoensis and warreni are brachypterous.

Key to species of the genus Hylobius in the Palaearctic region

1(4) : Elytra parallel-sided on basal two-thirds ; hind wings functional, normal.

2(3): Scales ochreous to yellowish; scutellum flat, shiny, with a few punctures: length 12-16 $\mathrm{mm}$; Europe, Siberia ….................. Hylobius piceus (DeGeer)

3(2): Scales greyish; scutellum weakly convex, with setigerous punctures and minute setae; length 11-15 $\mathrm{mm}$; eastern Siberia and Sakhalin

4(1): Elytra widest at apical third; hind wings short, not functional.

$5(6)$ : Sixth segment of antennal funicle a little longer than wide and distinctly longer than the fifth; scales ochreous on dorsum and greyish on ventrum; scutellum subtriangular, punctate on median and basal area, each puncture bearing a yellowish seta; pronotum with median area similarly scales as on margins ; aedeagus with the inner membraneous part of parameres of the same width around the median notch; length 10.7-13 mm; central Honshu

Hylobius adachii Kôno

6(5) Sixth segment of antennal funicle as wide as or a little wider than long; scales greyish, scaly patches on elytra smaller and sparser, scales on median area of pronotum much smaller than those on margins; scutellum with a few minute setae; aedeagus with the inner membraneous part of of parameres narrower at the median notch; length 13-15 mm. Hokkaido

Hylobius ezoensis sp. nov.

Hylobius ezoensis sp. nov. (Figs. 10; 46 D)

Hylobius albosparsus Kôno(nec Boheman), 1936, Biogeogr., 1(2) : 98 (Sounkyo, Berg. Daisetsu).

Male. Black, legs and antennae reddish black, with narrow greyish scales; head with sparse fine setae and with a greyish patch on each side above eye formed of narrow scales; prothorax with sparse greyish narrow scales on lateral and basal margins, median area of pronotum with sparse fine setae as on head; elytra with small, greyish irregular spots.

Head with small dense punctures and sparse setae; forehead between eyes two-thirds the width of the base of rostrum, with a deep median fovea. Rostrum a little shorter than pronotum, almost parallel-sided to the middle, weakly dilated apically thence, evenly curved before the middle; dorsum with rather strong punctures, the punctures being smaller at apical area, with a trace of median carina on basal half, lateral sulci above antenna1 scrobes deep. Antennae with proportions of funicular segments in length from base

* For the identification of albosparsus, I tentatively follow the definitions given by Motschulsky (1860), Reitter (1923) and Kôno (1934). But those definitions do not agree with the original description in the shape of elytra, and true albosparsus is seemed to be similar to a species of Lepyrus. 


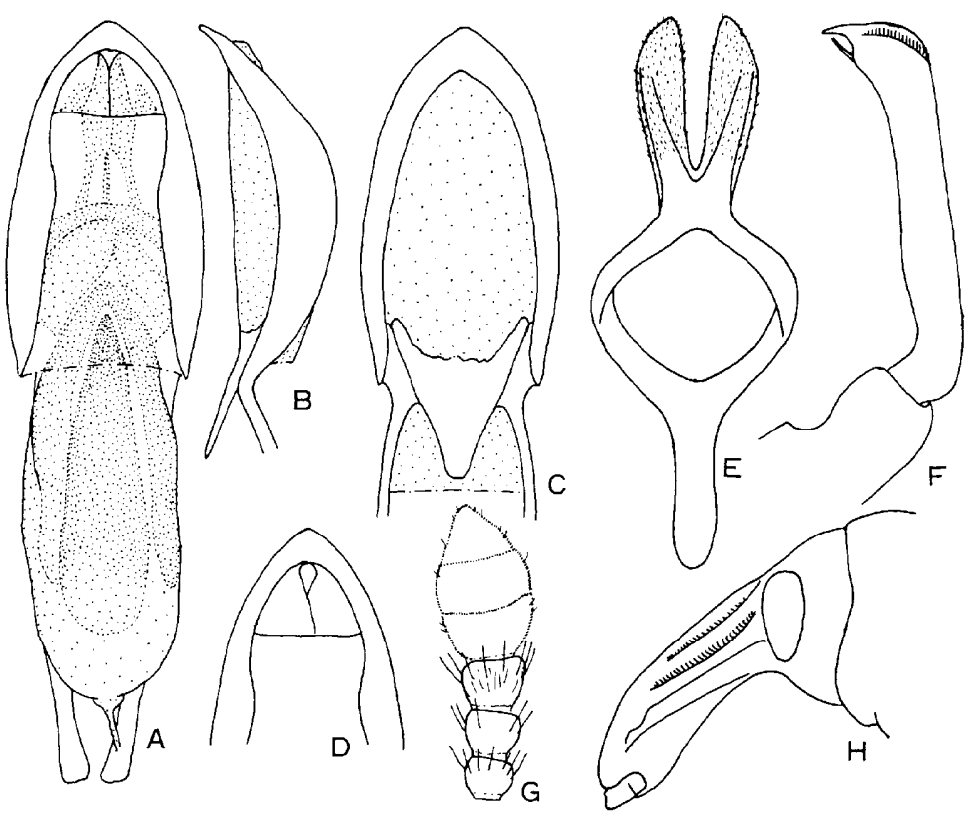

Fig. 10. Hylobius ezoensis sp. nov., male. A : Penis, dorsal. B : Ditto, lateral. C : Ditto, ventral. D : Apex of penis. E : Tegmen and parameres. F : Fore tibia. G: Distal segments of antenna. H: Head and rostrum.

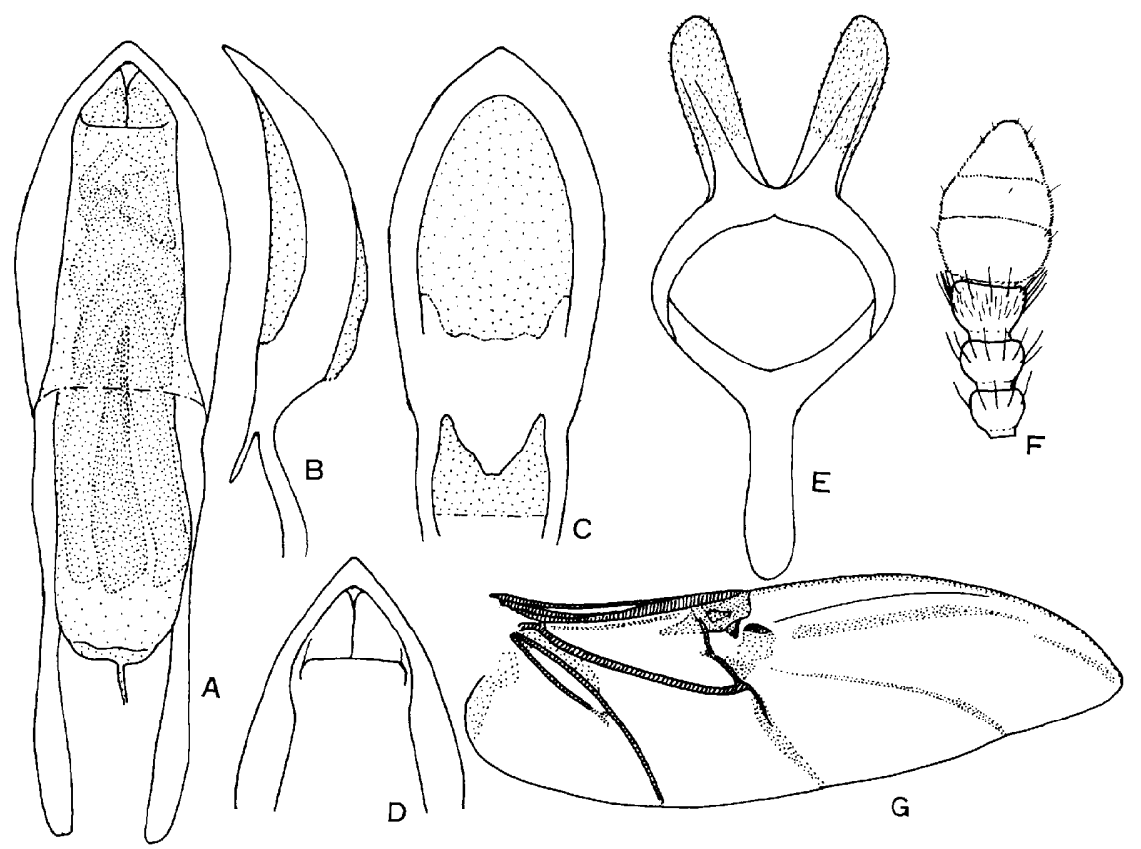

Fig. 11. Hylobius albosparsus Motschulsky from N. E. China, male. A : Penis, dorsal. B : Ditto, lateral. C : Ditto, ventral. D : Apex of penis. E: Tegmen and parameres. F : Distal segments of antenna. G : Hind wing. 


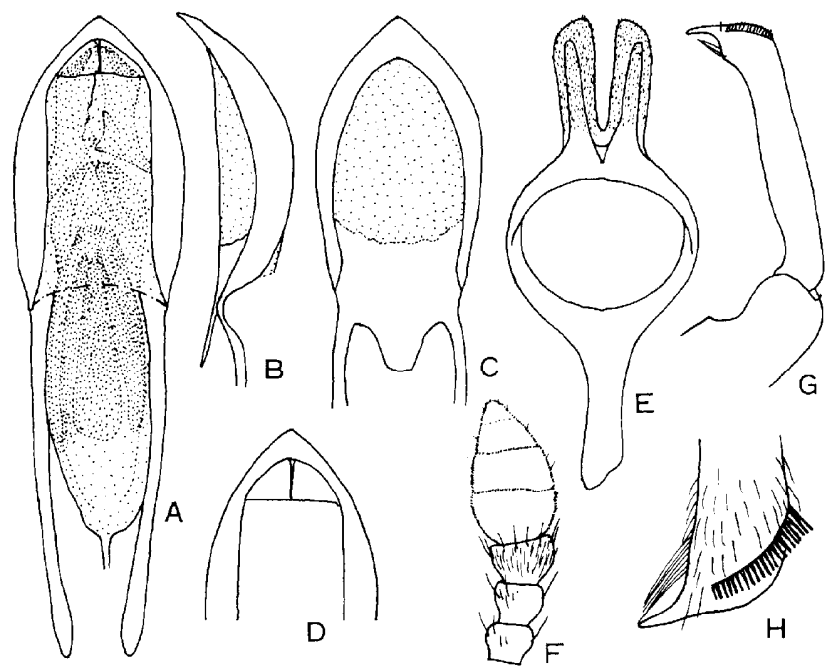

Fig. 12. Hylobius albosparsus Motschulsky from Sakhalin, male. A : Penis, dorsal. B : Ditto, lateral. C : Ditto, ventral. D : Apex of penis. E : Tegmen and parameres. F : Distal segments of antenna. G : Fore tibia. H : Apex of hind tibia.

as $24: 17: 8: 8: 8: 9.5: 10$, width of seventh 13 , club compact, first segment as long as second.

Prothorax as long as wide, rounded laterally, widest at the middle, posterior margin a little wider than the anterior one, subapical constriction deep on ventral and lateral sides, postocular lobes feeble ; dorsum coarsely wrinkledpunctate and tuberculate, unpunctate median carina abbreviate at anterior and posterior margins, weakly depressed on each side of the carina, the punctures smaller before the subapical constriction.

Scutellum a little longer than wide, subcordiform, with sparse shallow punctures and fine setae.

Elytra 1.5-l. 6 times as long as wide, widest behind the middle, weakly and straightly narrowing anteriorly to the humeri, rounded posteriorly to the apex; intervals flat, wrinkled-punctate, interstices often convex forming low tubercles; striae with regular deep punctures, which becoming smaller toward apex behind declivity.

Venter sparsely punctate, the punctures a little denser at sides and on fifth vetrite, first and second ventrites depressed in the middle. Aedeagus as figured.

Female. Unknown.

Length : 13.0-15 $0 \mathrm{~mm}$ (excl. rostrum).

Holntype ठ̛ (Type No. 2364, Kyushu Univ.), Shikaribetsu, Tokachi, Hokkaido. 8. viii. 1937, T. Esaki leg.

Paratypes: Sounkei, Mt. Daisetsu, Hokkaido, $2 ð, 7$ \& 8. vi. 1953, H. Kôno leg. 


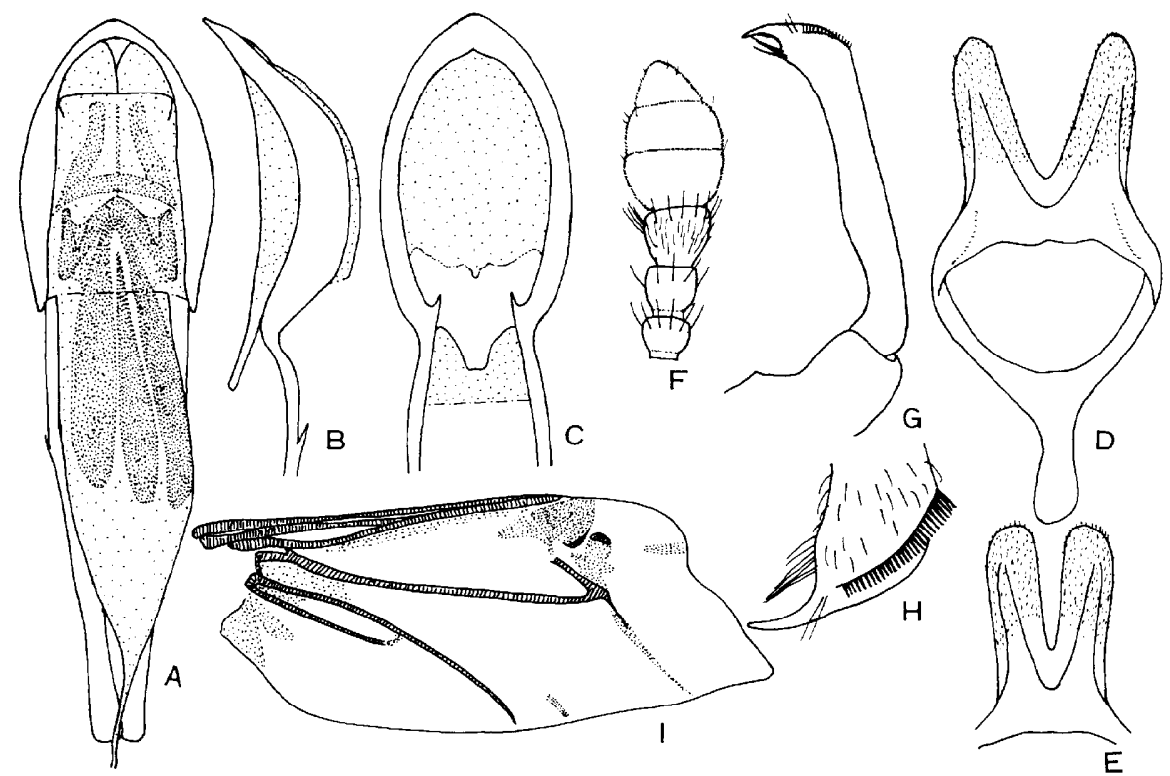

Fig. 13. Hylobius adachii Kôno, male. A : Penis, dorsal. B : Ditto, lateral. C : Ditto, ventral. D : Tegment and parameres. E : Parameres. F: Distal segments of antenna. G : Fore tibia. H : Apex of hind tibia. I : Hind wing. (E : from Mt. Senjodake, the other from Mt. Kiso-Koma).

DistRibution : Japan (Hokkaido) .

HOST TREE: Kôno got those specimens on living Abies sachalinensis.

This new species is a brachypterous form and closely related to albosparsus Boheman and adachii Kôno, but separable from them by the characters noted in the key.

Hylobius adachii Kôno (Figs. 13; 46C)

Hylobius adachii Kôno, 1934, Journ.Fac. Agr. Hokkaido Imp. Univ., XXXIII (3) : 229 (Chichibu, male); Kamimura, Nakane \& Koyama, 1964, Sci. Rep. Kyoto Pref. Univ., (15) A: 36 (Mt. Jonen).

Specimens examined: Nikamatazawa, Mt. Shirane, Gunma Pref., 1 우, 16. vii. 1975, H. Irie leg. Zara-toge, Mt. Tateyama, Toyama Pref., 1우, 27. vii. 1952, C. Tanaka leg. Tsurugitake, Toyama Pref., 1ð, 16. vii. 1961, K. Kimura leg. Shibunoyu, Mt. Yatsugatake, Nagano Pref ., $2 \diamond^{2}$ 우, 29. vi. 1971, R. \& F. Ishikawa leg. Mt. Tateshinayama, Nagano Pref., 1ð, 30. vi. 1971, R. \& F. Ishikawa leg Mt. Senjotake, Nagano Pref., 1ð, 25. vii. 1962, A. Ogura leg. Mt. Kiso-Koma, Nagano Pref., $1 \delta^{\Uparrow} 1$ 우, 25. viii. 1962, K. Morimoto leg.

Distribution : Japan (Honshu : high altitude area of central Honshu).

In the fresh specimens scalings are ochreous to brownish ochreous and more evenly covering the dorsal surface of pronotum and elytra than the related species. 


\section{Dyscerus Faust}

Dyscerus Faust, 1892, Stett. Ent. Zeit., LIII: 198, 203; Heller, 1929, Abh. Zool. Mus. Dresden, XVII (3) :12; Marshall, 1948, Novit. Zool., 42: 399; Aslam. 1963, Bull. British Mus (Nat. Hist.), Ent., 13 (3) : 61. Type-sepies Hylobius macilentus Boheman, by original designation.

Okikuruminus Kôno, 1934, Journ.Fac. Agr., Hokkaido Imp. Univ., XXX111 (3) : 241; Morimoto, 1962, Journ.Fac. Agr., Kyushu Univ., 12: 64. Type-species: Curculio roelofsi Harold, by original designation. Syn. nov.

Hypohylobius Voss, 1934, Ent. Bachrbl., VIII : 78 (as a subgenus of Hylobius). Type-species : Hylobius (Hypohylobius) subinflatus Voss, by monotypy. Syn. nov.

Hylobius (partim): Zumpt, 1932, Kol. Rdsch., XVIII : 130; Kôno, 1934, Journ.Fac. Agr., Hokkaido Imp. Univ., XXX111 (3) : 226 ; Morimoto, 3963, Journ.Fac. Agr., Kyushu Univ., 12: 64 .

The genus Dyscerus I defined here is rather heterogeneous assemblage of species. The outer setose fringe of tarsal groove is weakly oblique in exsculptus, galloisi and gigas, and strongly ascended and flat S-shaped in the other species. A pair of setal tufts on the first ventrite are present in the both sexes of larviventris and roelofsi (also kanoi Kôno from Taiwan and subinflatus Voss from China), while in elongatus, gigas, galloisi and insularis, similar setae are present only in the male. Antennal club is usually oblong-oval, but in exsculptus, elongatus and insularis, it is compact and oval.

Okikuruminus and Hypohylobius were established for receiving the brachypterous species with oval elytra and with a pair of setal tufts on the first ventrite in both sexes.

Key to SPeCIES OF the genus Dyscerus in JaPan

1(4): Body length 5.4-8.0 mm (exc, rostrum) ; dorsal outline of rostrum forming an angle with forehead; first ventrite with a pair of hair tufts in male; elytra with a V-shaped hairy fascia from the side margins a little behind humeri to the middle of suture and with a transverse or weakly arched band between sixth interval at basal fourth; fresh specimens with white waxy powder on these bands and on declivity; antennal club compact, oval; penis not membraneous on the ventral side, widest at basal third, gently narrowing apically and with small point at apex.

2(3): Pronotum strongly wrinkled-punctate; elytra about twice as long as wide; dark reddish brown to black ….................... Dyscerus elongatus (Roelofs)

3(2): Pronotum reticulately punctate, their interstices slightly raised in the median and lateral areas; elytra 1.7-1.8 times as long as wide ; dark reddish brown to reddish brown, with black small patches on elytra ......

Dyscerus insularis Kôno

4( 1): Body length 7.9-16.0 $\mathrm{mm}$; rostrum continuous to forehead in profile; fresh specimens not or partly covered with white powder.

5( 6) : Elytra oval, widest in the middle; hind wings brachypterous; first ventrite with a pair of hair tufts in both sexes; pronotum very rugose, with irregular shiny granules and a short median carina before the middle; elytra separately acuminate at apex, intervals granulate; body length 9.5 $15.0 \mathrm{~mm}$

Dyscerus roelofsi (Harold)

6(5): Elytra parallel-sided on basal half. 
7(8): Metasternum and venter almost impunctate, coriarious; first ventrite with a pair of hair tufts in both sexes; pronotum rugosely granulate, each side of the sharp median carina depressed; elytra mottled with ochreous scales;

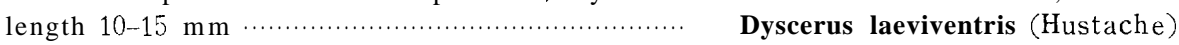

8( 7 ): Metasternum and venter punctate ; first ventrite without hair tufts at least in female; elytra with scaly bands or densely scaled on declivity.

9(14): Elytra with two bands formed of small hairy spots.

10(11): Length 7,9-10.9 $\mathrm{mm}$; pronotum strongly tuberculate, with a short or without median carina; elytra with large punctures in striae and transversely wrinkled; penis widely rounded and weakly notched at apex; black, with ochreous scaly patches

Dyscerus cribratus (Roelofs)

11(10): Length 11-16 mm.

12(13): Scutellum triangular, densely punctate; seventh segment of antennal funicle as long as wide ; elytra separately acuminate at apex; setose fringe of tarsal groove strongly ascended, brownish black to black; penis with sides evenly rounded and widely membraneous on ventral surface

Dyscerus shikokuensis (Kôno)

13(12): Scutellum rounded posteriorly, shiny, with sparse punctures at base; seventh segment of antennal funicle strongly dilated apically and transverse ; elytra conjointly rounded at apex; setose fringe of tarsal groove weakly ascended, yellowish brown to brown; penis rapidly narrowed at apex, with indistinct small membraneous area on ventral surface

Dyscerus exsculptus (Roelofs)

14(9): Elytra with dense scales and amorphous powder on declivity.

15(16): Rostrum with a small median projection at tip; pronotum wrinkled-granulate; elytra with an oblique short scaly band behind shoulder, third, fifth and seventh intervals with shiny granules ; penis parallel-sided, narrowed near ostium, membraneous on dorsal and ventral surfaces

Dyscerus orientalis (Motschulsky)

16(15): Rostrum without a median projection at tip.

17 (20): Pronotum on each side and elytra around shoulders densely covered with scales and powder as on declivity; pronotum with conical granules, widest before the middle, rounded at sides; elytra each triangularly acuminate at apex.

18(19): Elytra slenderer, 1. 65-1.80 times as long as wide, widest at shoulders, almost parallel-sided to the $1 / 3$ from apex, with distinct tuberclk on the declivity of fifth interval; penis strongly sclerotized, a narrow area around ostium and a semicircular area on the ventral surface membraneous, strongly bent, the sides narrowed towards ostium, then widening distal-

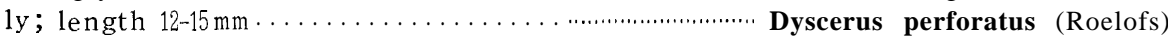

19(18): Elytra robust, 1.5-1. 6 times as long as wide, parallel-sided on basal half, with weak tubercle on the declivity of fifth interval; penis membraneous on the dorsal surface, the sides gradually narrowing distally and rounded

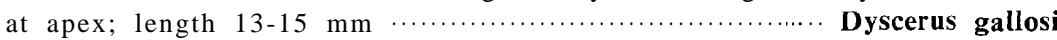

20(17): Pronotum with granules more or less confluent, widest at base, slightly constricted at $1 / 3$ from base ; pronotum and basal area of elytra sparsely scaled ; elytra robust, 1.5 times as long as wide, with very large punctures in striae, mucronate at apex; penis parallel-sided, with a small projection at apex, membraneous on dorsal surface, internal sac with a pair of black, shiny and denticulate sclerites in the middle and a pair of asperate area near gonopore; length $12-16 \mathrm{~mm}$

Dyscerus gigas (Kôno) 

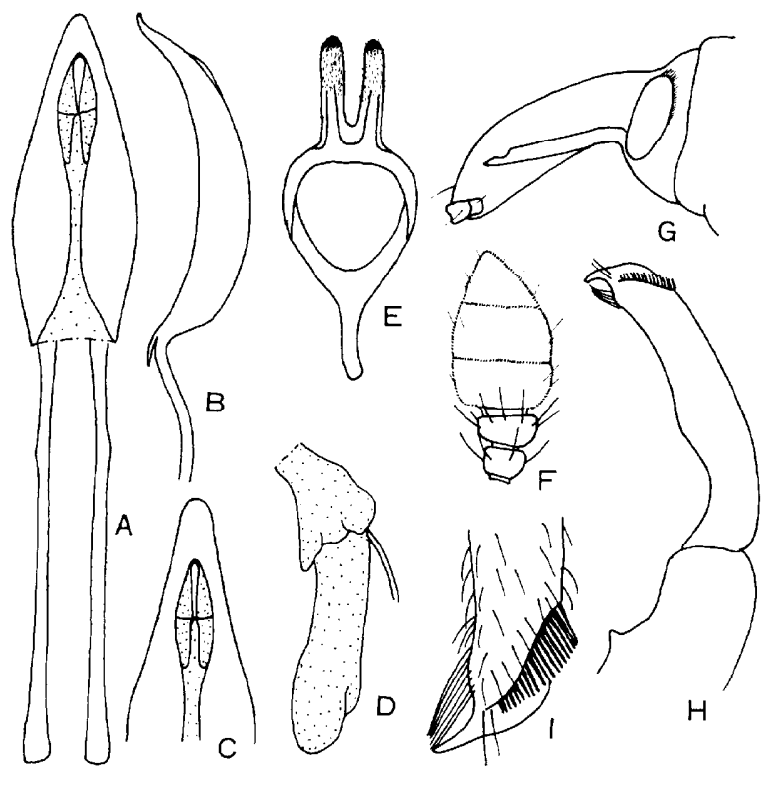

Fig. 14. Dyscerus elongatus (Roelofs), male. A : Penis, dorsal. B : Ditto, lateral. C: Apex of penis. D: Internal sac, lateral. E : Tegmen and parameres. F : Distal segments of antenna. $\mathrm{G}$ : Head and rostrum. H : Fore tibia. I : Apex of hind tibia.

\section{Dyscerus elongatus (Roelofs) (Fig. 14)}

Hylobius elongtus Roelofs, 1873, Ann. Soc. Ent. Belg., XVI: 190 (Japon) :Kôno, 1934, Journ. Fac. Agr., Hokkaido Imp. Univ., XXX111 (3) : 237 (Honshu) ; Nakane, 1963, Icon. Ins. Jap. Col. nat. ed., II: 368, pl. 184, fig. 15,

Dyscerus elongatus: Faust, 1892, Stett. Ent. Zeit., LIII: 198.

Pagiophloeus elongatus : Dalla Torre et Schenkling, 1932, Col. Cat., 122: 21.

Specimens examined: 75 specimens from Niigata (Senami, Sado), Nagano (Ina, Asama), Kyoto (Mizoroike, Kifune), Nara (Kasuga), Osaka (Minoo, Mt. Iwawaki), Hyogo (Kobe), Okayama (Takahashi), Tottori (Daisen), Kagawa (Mt. Zoozu), Kochi (Jinzenji, Ashizuri), Fukuoka (Mt. Hikosan, Yahata, Mt. Sangunzan, Mt. Wakasugi), Nagasaki (Mt. Iwaya, Mt. Hoba), Oita (Mt. Katamuki), Kumamoto (Tatsudayama), Is. Yakushima (Shiratani), and Tsushima (Mt. Ariake).

Distribution : Japan (Honshu, Shikoku, Kyushu, Tsushima, Is. Yakushima).

Fresh specimens are usually covered with white waxy poder on elytra, and often parasitized externally by mites on declivity. Adults are often cap. tured on the dead pine trees.

Dyscerus insularis Kôno (Fig. 15)

Dyscerus insularis Kôno, 1928, Ins. Mats., II : 168, T. 6, fig. 17 (Nopporo). Pagiophloeus insularis : Dalla Torre et Schenkling, 1932, Col. Cat., 122: 21. Hylobius insularis: Kôno, 1934, Journ. Fac. Agr. Hokkaido Imp. Univ., XXX111 (3) : 237. 


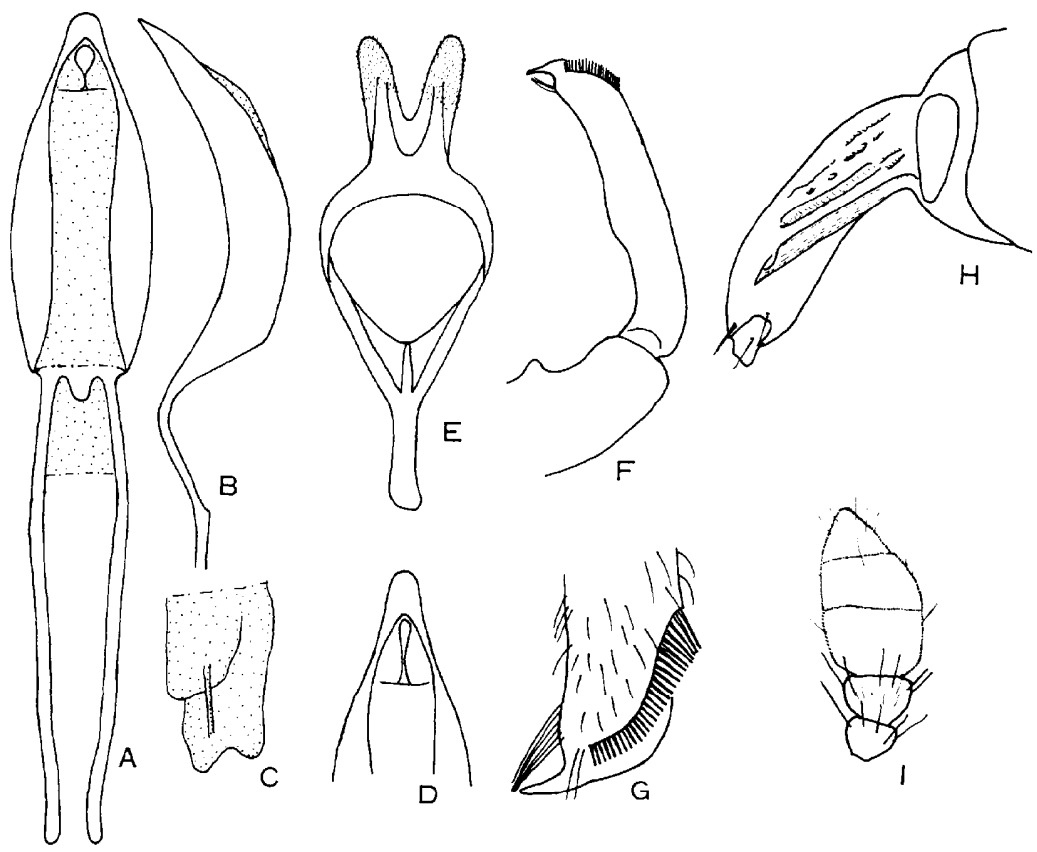

Fig. 15. Dyscerus insularis Kôno, male, A : Penis, dorsal. B : Ditto, lateral. C : Internal sac, dorsal. D : Apex of penis. E: Tegmen and parameres. F : Fore tibia. G : Apex of hind tibia. $\mathrm{H}$ : Head and rostrum. I : Distal segments of antenna.

Specimens examined: Nikko, Tochigi Pref., 1 ㅇ, 14. vii. 1956, S. Kimoto leg. Ina, Nagano Pref., 1ð,1. vi. 1962, K. Morimoto leg. ;1ð, 21. viii. 1962, Y. Miyatake leg. Tibirakozan-Tobiratoge, Nagano Pref., 1우, 21. vii. 1975, H. Irie leg. Mt. Hikosan, Fukuoka Pref., 1우, 13. vi. 1957, K. Morimoto leg.

Distribution : Japan (Hokkaido, Honshu, Kyushu) .

Host TREE : Abies sachalinensis.

Fresh specimens are covered with white waxy patches on elytra, which are transversely confluent before the middle on the fourth to eighth intervals in a band and also on the first to fourth intervals in two bands.

Dyscerus galloisi (Kôno), comb. nov. (Fig. 16)

Hylobius galloisi Kôno, 1934, Journ.Fac. Agr.. Hokkaido Imp. Univ., XXXIII (3) : 235, Taf.

V, fig. 4 (Sapporo, Yonezawa, Chuzenji):Kôno, 1950, Icon. Ins. Jap.: 1265, fig. 3647.

Hylobius perforatus: Morimoto (nec Roelofs), 1962, Bull. Gov. Forest Exp. Sta., (143) : 2 (Hokkaido, Honshu, Kyushu).

Specimens examined : Ashorobuto, Hokkaido, 1o1우,1-3. vii. 1958, S. Miyamoto leg. Mt. Moiwa, Hokkaido, $1 \precsim 1$ 우, 12. vii. 1956, Y. Takenouchi leg. Kurokawa, Niigata Pref ., 1ð, 3. v. 1964, K. Baba leg. Misakubo, Shizuoka Pref., 1ð, 22. viii. 1955, K. Kojima leg. Inugatake, Fukuoka Pref., $1 \gtrsim 1$ 우, 14. vii. 1938, H. Hori leg. Kumado, Fukuoka Pref., 1ð, 10. v. 1959, Y. Miyake leg. 


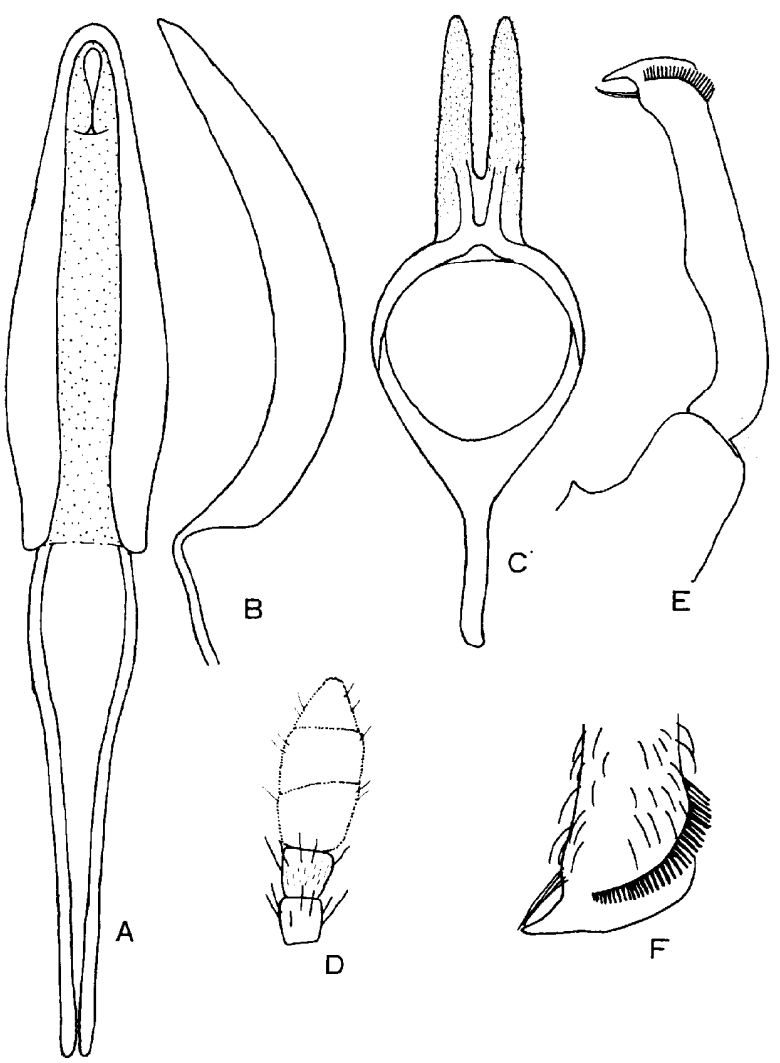

Fig. 16. Dyscerus galloisi (Kbno), male. A : Penis, dorsal. B: Ditto, lateral. C : Tegmen and parameres. D : Distal segments of antenna. E : Fore tibia. F : Apex of hind tibia.

Distribution : Japan (Hokkaido, Honshu, Kyushu).

Host trees: Fraxinus spaethiana, $F$. mandschrica var. japonica, and $\boldsymbol{F}$. japonica.

Dyscerus gigas (Kôno), comb. nov. (Fig. 17)

Hylobius gigas Kôno, 1934, Journ.Fac. Agr., Hokkaido Imp. Univ., XXX111 (3) : 236, Taf. V, f. 1 (Jozankei, Berg Eniwa) ; Nakane, 1963, Icon. Ins. Jap. Col. nat. ed., II: 368, pl. 184, fig. 16 (Hokkaido, Honshu, Kyushu).

Specimens examined: Mt. Hikosan, Fukuoka Pref., 1ð, vi. 1957, T. Esaki leg. ;1ð, 11. ix. 1974, K. Morimoto leg. Locality ?, 1ð, 24. viii. 1960.

Distributron : Japan (Hokkaido. Honshu, Kyushu).

Host tree : Acer mono.

Dyscerus cribratus (Roelofs) (Fig. 18)

Hylobius cribratus Roelofs, 1873, Ann. Soc. Ent. Belg., XVI: 190 (Japon) ; Kbno, 1934, Journ. Fac. Agr., Hokkaido Imp. Univ., XXXIII (3) : 23‘2 (Honshu, Shikoku); Nakane, 1963, Icon. Ins. Jap. Col. nat. ed., II: 367, pl. 184, fig. 9. 


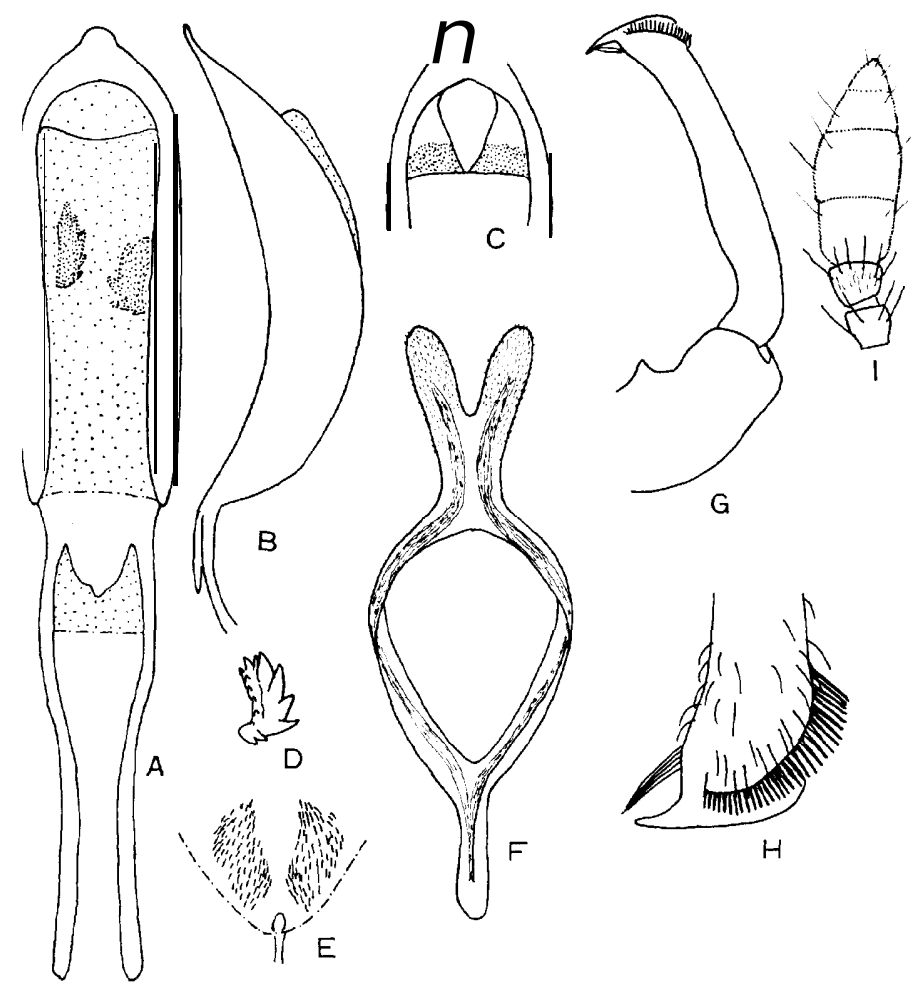

Fig. 17. Dyscerus gigas (Kôno), male. A : Penis, dorsal. B : Ditto, lateral. C : Apex of penis. D : Sclerite of internal sac. E : Internal sac showing gonopore and brown asperities. F : Tegmen and parameres. G : Fore tibia. H : Apex of hind tibia. I : Distal segments of antenna.

Dyscerus cribratus: Faust, 1892, Stett. Ent. Zeit., LIII: 198.

Pagiophloeus cribratus: Dalla Torre et Schenkling, 1932, Col. Cat., 122: 22.

Specimens examined: Yunomata, Ohata, Aomori Pref., 1 , 9. vii. 1956, K. Morimoto leg. Mt. Gagyusan, Okayama Pref., 1ㅇ, 19-20. v. 1975, H. Irie leg. Erimon, Kochi Pref., 1ð, 10. viii. 1952, H. Kashiwabara leg. Mt. Tebako, Kochi Pref., 1우, 8. viii. 1962, K. Ueda leg. Kashii, Fukuoka Pref., 1む, 7. vii. 1954, K. Morimoto leg. Mt Hikosan, Fukuoka Pref., $1 \delta^{\star}, 5$. viii. 1955, S. Nakao leg. Mt. Sefuri, Fukuoka Pref., 1ð, 3. v. 1955, H. Kamiya leg. Mt. Kanayama, Fukuoka Pref., 16, 15. vi. 1958, K. Morimoto leg. Mt. Homan, Fukuoka Pref., 1ð, 15. v. 1975, H. Irie leg. Shiiya-toge, between Miyazaki and Kumamoto. 1 ㅇ, 8. vi. 1975, S. Ogata leg. Cape Sata, Kagoshima Pref., 1 ㅇ , 27. v. 1958, Y. Miyake leg.

Distribution : Japan (Honshu, Shikoku, Kyushu).

Host TREE : Unknown. 


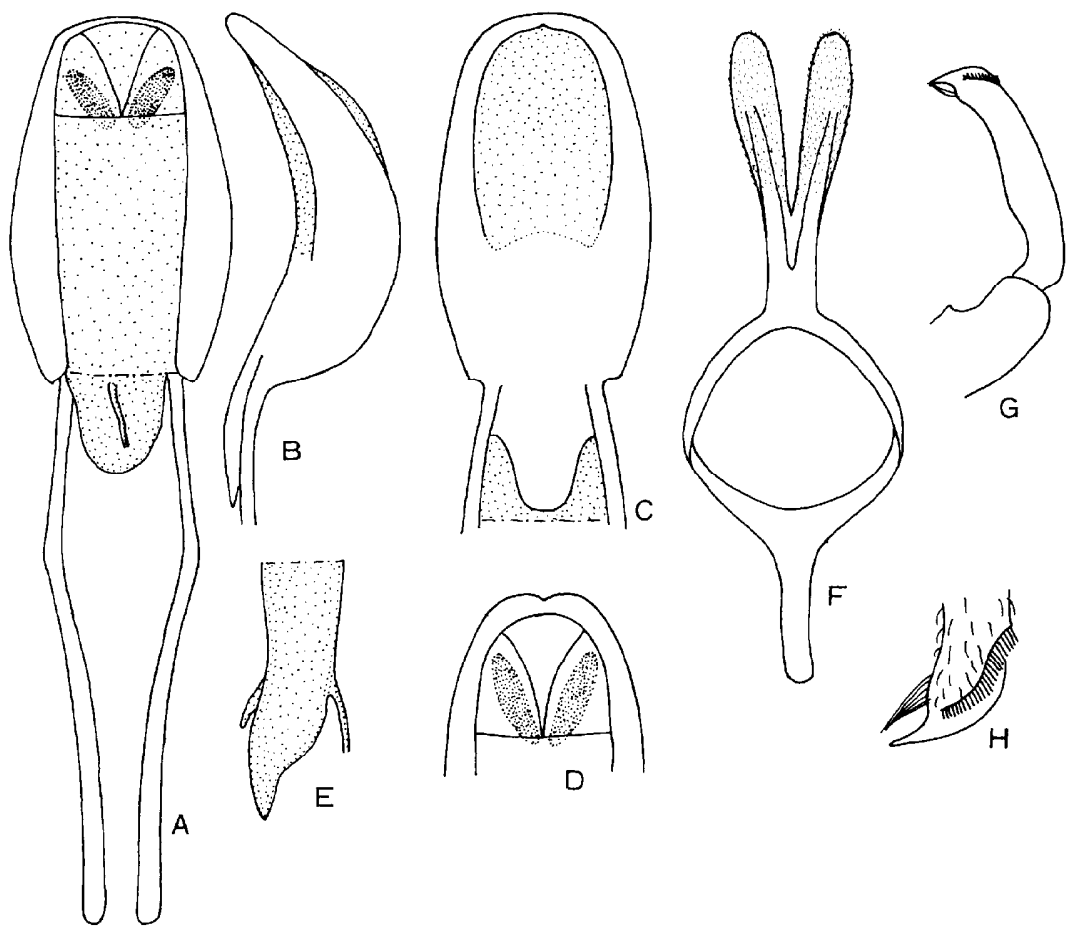

Fig. 18. Dyscerus cribratus (Roelofs), male. A : Penis, dorsal. B : Ditto, lateral. C : Ditto, ventral. D: Apex of penis. E: Internal sac, lateral. F: Tegmen and parameres. G : Fore tibia. H : Apex of hind tibia.

Dyscerus exsculptus (Roelofs), comb. nov. (Fig. 19)

Hylobius exsculptus Roelofs, 1875, Ann. Soc. Ent. Belg., Compt. Rend., XVII: cxxx (Kioto, Hiogo).

Hylobius freyi Zumpt, 1932, Kol. Rdsch., XVIII: 128 (Sado, Umgebung Tokyo, Nikko, Norobetsu Onsen, Yokohama) ; Kôno, 1934, Journ.Fac. Agr., Hokkaido Imp. Univ., XXX111 (3) : 232, Taf. V, fig. 3, Taf. VI, fig. 10 (Hokkaido, Honshu, Shikoku) ; Nakane, 1963, Icon. Ins. Jap. col. nat. ed., II: 368, pl. 184, fig. 14 . Syn. nov.

Hylobius matsumurai Zumpt, 1938, Ent. Blätt., 34: 82 (new name for H. freyi Kôno, 1934, nec Zumpt). Syn. nov.

Specimens examined : 26 specimens from Niigata (Kanamaru, Niitsu), Toyama (Tateyama), Ibaragi (Tsuchiura), Chiba (Mt. Kiyosumi), Tokyo (Kobotoke), Nagano (Tadeshina, Mt. Yatsugatake), Gifu (Nagara), Gunma(Oneyama), Okayama (Fukumoto), Tokushima (Anabuki), Fukuoka (Kumado) and Kumamoto (Tatsudayama, Hitoyoshi, Yabe, Ueki).

Distribution : Japan (Hokkaido, Honshu, Shikoku, Kyushu).

This species has been confused with shikokuensis Kôno due to external similarity in the coloration, markings and size. They are, however, easily separable to each other by the shapes of scutellum, seventh segment of an- 


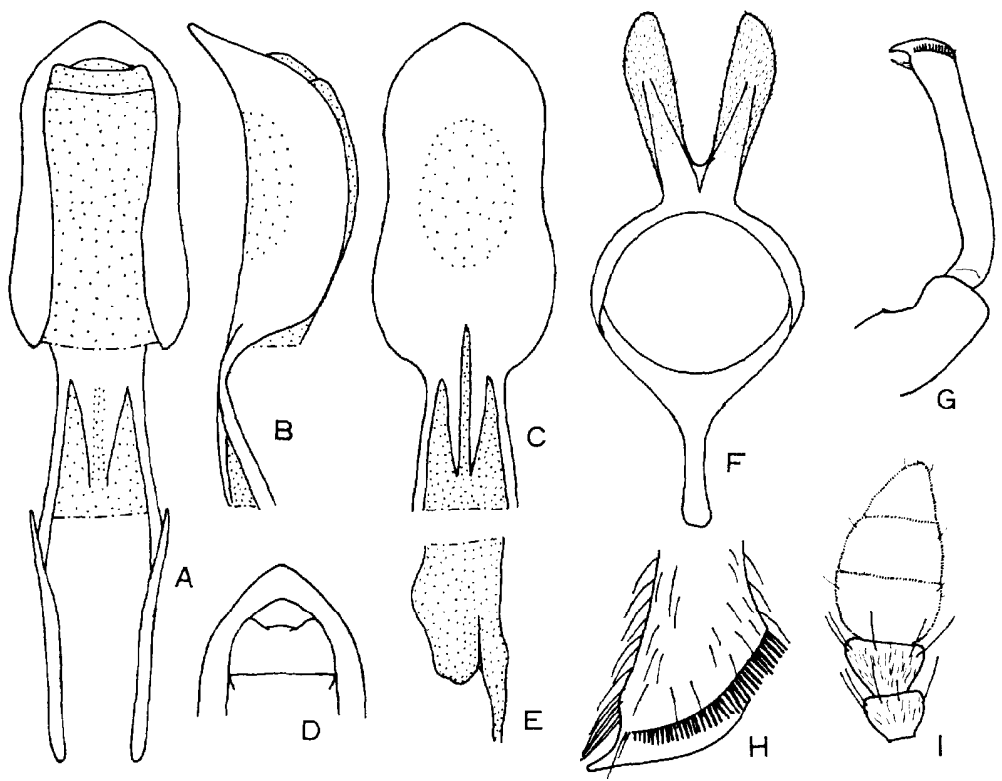

Fig. 19. Dyscerus exsculptus (Roelofs), male. A : Penis, dorsal. B : Ditto, lateral. C : Ditto, ventral. D : Apex of penis. E : Interenal sac, lateral. F : Tegmen and parameres. G : Fore tibia. H : Apex of hind tibia. I : Distal segments of antenna.

tennal funicle and apices of elytra as noted in the key. So far as I have examined the specimens identified by Kôno, which were once recorded in his revision (1934) as freyi and later relabelled as exsculptus are true exsculptus. $H$. freyi is the same as exsculptus judging from the original descriptions as “..Schildchen glänzend, .. breit abgerunded. Fiihler.. das siebent fast doppelt so breit wie lang", and from the illustration of the penis. The treatment by Zumpt (1938) baffles my understanding why he gave a new name, matsumurai, for Kôno's freyi.

The larvae of this species feed on the subcortical part of the chestnut tree trunk a little below the ground surface, and cause the severe damage in some orchards.

Dyscerus shikokuensis (Kôno), comb. nov. (Fig. 20)

Hylobius shikokuensis Kôno, 1934, Journ.Fac. Agr., Hokkaido Imp. Univ., XXXIII (3) : 234, Taf. V, fig. 5 (Awa).

Hylobius yakui Kôno, 1934, Journ. Fac. Agr., Hokkaido Imp. Univ., XXXIII(3): 234, Taf. V, fig. 8, Taf. VI, fig. 11. (Sapporo, Minomo). Syn. nov.

Specimens examined : 35 examples from Hokkaido (Yoichi, Sapporo), Aomori (Kuroishi), Iwate (Ninohe), Yamagata (Sakata, Mt. Chokai), Akita (Kisakata), Tottori (Daisen), Kyoto (Mt. Hiei), Osaka (Mt. Iwawaki), Hiroshima (Shobara), and Kagoshima (Takachihonomine).

Distribution : Japan (Hokkaido, Honshu, Shikoku, Kyushu). 


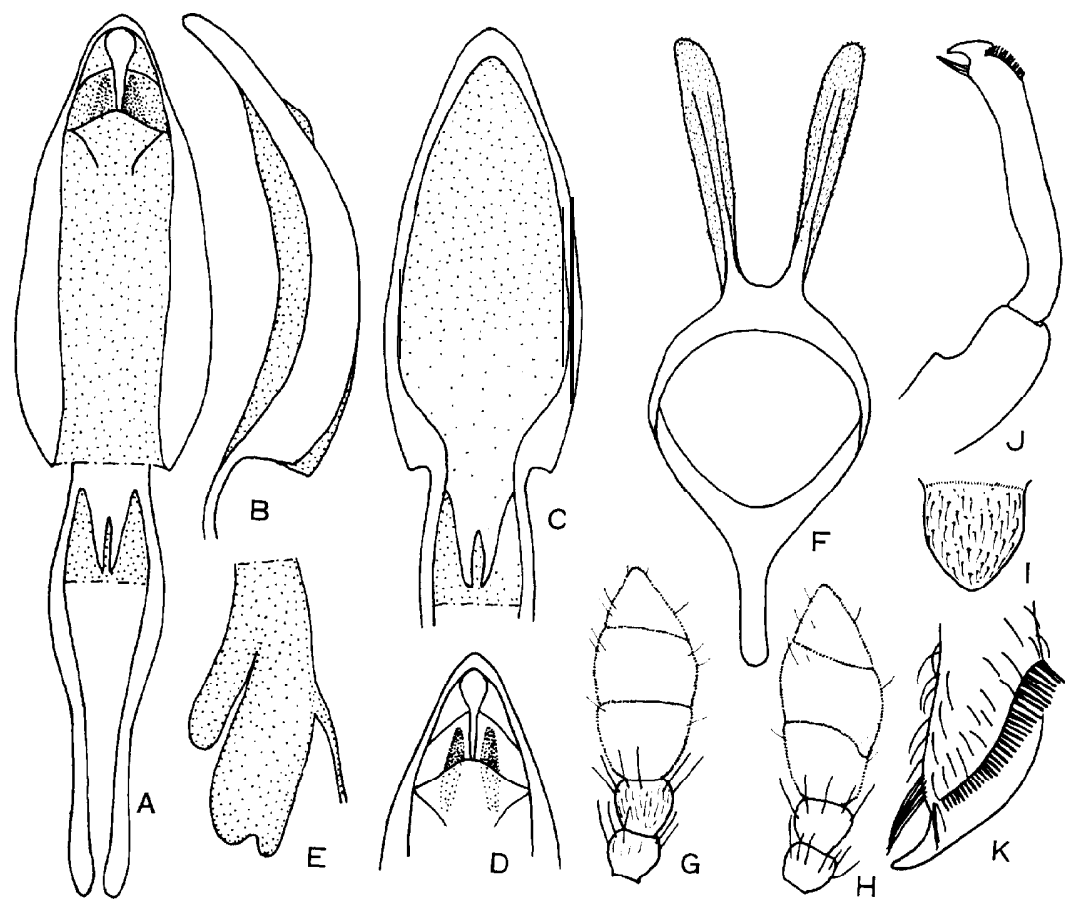

Fig. 20. Dyscerus shikokuensis (Kôno), male. A : Penis, dorsal. B : Ditto, lateral. C : Ditto, ventral. D: Apex of penis. E : Internal sac, lateral. F : Tegmen and parameres. G, H: Distal segments of antenna, showing partly oblique suture. I : Scutellum. J : Fore tibia. K : Apex of hind tibia.

H ost trees: Malus domestica, Prunus jamasakura, $P$. yedoensis, $P$. avium a $\mathrm{nd}$ P. persica.

The larvae feed on the basal part of the living trunk of the cherry and apple trees. Many records so far published as the pest of these trees as freyi are seemed to be on this species.

Dyscerus orientalis (Motsuhulsky), comb. nov. (Fig. 21)

Heilipus orientalis Motschulsky, 1866, Bull. Soc. Nat. Mosc., XXXIX: 180 (Japon)

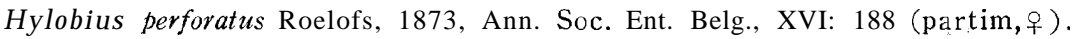

A clees hylobioides Desbrochers, 1891, Ann. Soc. Ent. Belg., XXX?, Compt. Rend.: ccclii (China).

Pagiophloeus hylobloides: Faust, 1894, Stett. Ent. Zeit., LX: 359.

Hylobius macilentus: Matsumura (nec Boheman), 1915, Dainihon Gaichu Zensho, II: 222 (Okinawa) ; Hidaka, 1921, Bull. Forest Exp. Sta., (5) : 17 (biology).

Hylobius orientalis: Zumpt, 1932, Kol. Rdsch., 18: 132 (redescr.) ;Kôno, 1934, Journ.Fac. Agr., Hokkaido Imp. Univ., XXXIII (3) : 237; Kôno and Kim, 1937, Journ. Chosen Nat. Hist. Soc., 22: 21 (Korea) ; Ichihashi, 1956, Shin Konchu, 9(3) 47 (Mie, hibernation) ; Morimoto, 1962, Bull, Gov. Forest Exp. Sta., (143) : 1 (=okinawanus, synonymic list).

Hylobius perforatus: Matsushita (nec Roelofs), 1943, Shinrin Gaichugaku, 288 (Biolgy) ; Inouye,. 1953, Shinrin Gaichu Bojoron, II : 133 (Biology). 


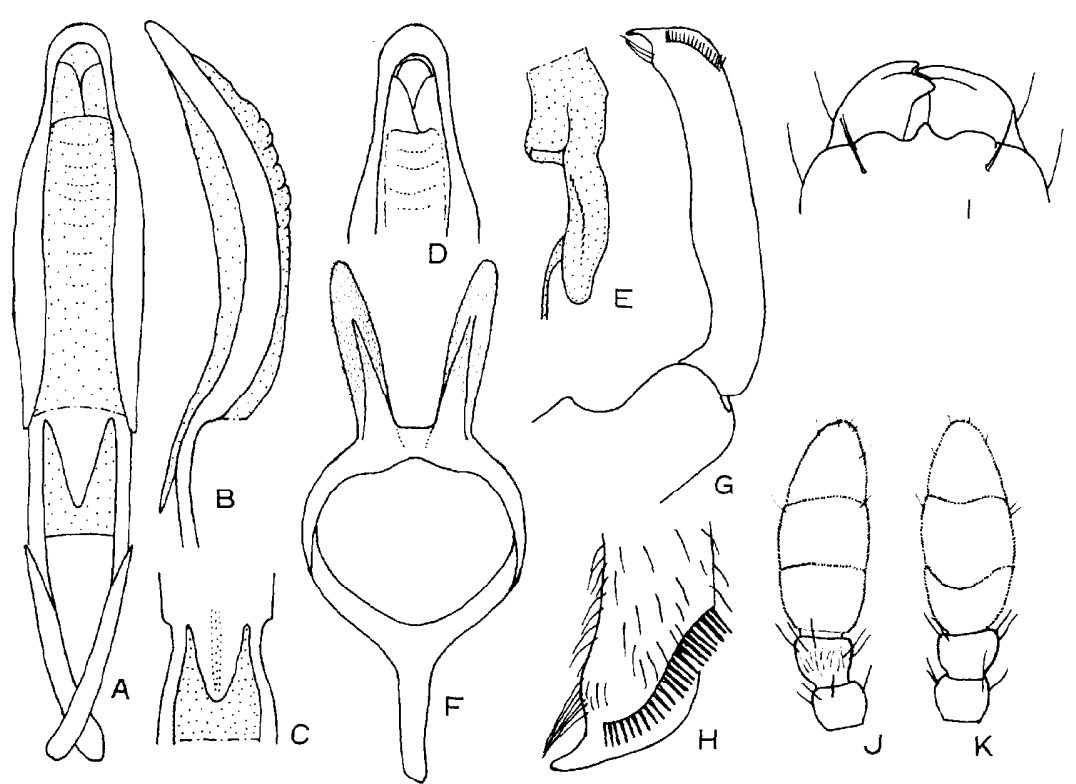

Fig. 21. Dyscerus orientalis (Motschulsky), male. A : Penis, dorsal. B : Ditto, lateral. C : Basal part of penis, ventral. D : Apex of penis. E : Internal sac, 1ateral. F : Tegmen and parameres. G : Fore tibia. H : Apex of hind tibia. I : Apex of rostrum. $\mathrm{J}, \mathrm{K}:$ Distal segments of antenna.

Hylobius okinawanus Kôno, 1934, Journ.Fac. Agr. Hokkaido Imp, Univ., XXX111 (3) : 237 (Okinawa).

Specimens examined : 31 examples from Kochi (Jinzenji), Fukuoka (Mt. Tachibana), Nagasaki (Mt. Iwaya, Mt. Tara), Miyazaki (Mt. Aoidake), Kagoshima (Odomari), Is. Yakushima (Shiratani, Kosugidani, Kusukawa- hodo), Is. Nakanoshima, Is. Amami-Oshima (Sumiyo-son), and Is. Okinawa (Nago, Oku).

Distribution: Japan (Honshu, Shikoku, Kyushu, Isls. Yakushima, Nakanoshima, Amami-Oshima and Okinawa), China.

H ost t tees : Cinnamomum camphora, C. japonicum, Illicium religiosum, Machilus thunbergii, Neolitsea sericea and Actinodaphne lancifolia (Lauraceae).

This species has a small median projection at the apex of rostrum as in some species of Pagiophloeus.

Dyscerus perforatus (Roelofs), comb. nov. (Fig. 22)

Hylobius perforatus Roelofs, 1873, Ann. Soc. Ent. Belg., XVI: 188 (Japon) ; Yokoyama, 1931, Zoku Nihon no Kochu: 61, pl. 8, fig. 9; Kamiya \& Adachi, 19.33, Genshoku Kochu Zufu, pl. 43, fig. 8; Kate, 1933, Bunrui Genshoku Konchu Zukan, 9, pl. 24, fig. 7; Kôno, 1934, Journ.Fac. Agr., Hokkaido Imp. Univ., XXXIII : 239.

Curculio perforat us: Hoffmann, 1963, in Balachowsky, Ent. Appl. Agr. (Masson) I: 997.

Aclees Roelosi Desbrochers, 1891, Ann. Soc. Ent. Belg., XXXV; Compt. Rend.: cccli (Japon). Pagiophloeus Roelofsi: Faust, 1892, Stett. Ent. Zeit., LIII: 50.

Dyscerus cribripennis Matsumura et Kôno, 1928, Ins. Mats., II : 168 (Is. Hachijo). 

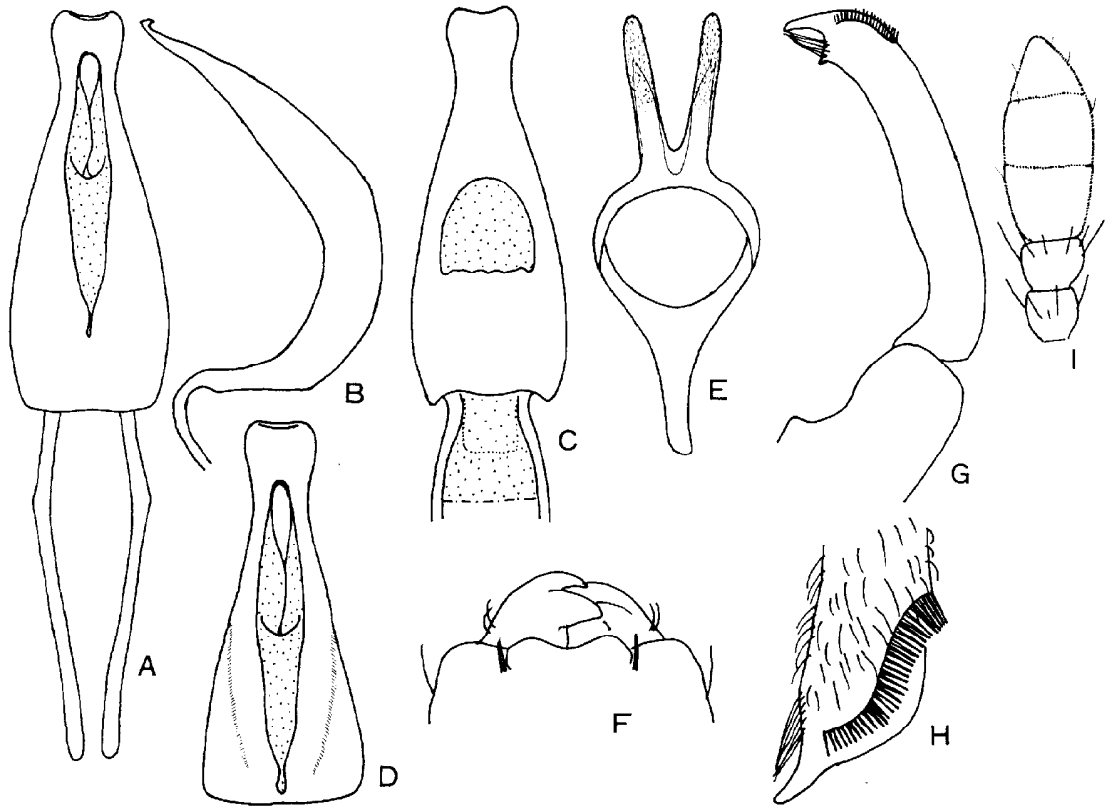

Fig. 22. Dyscerus perforatus (Roelofs), male. A : Penis, dorsal. B : Ditto, lateral. C : Ditto, ventral. D : Apex of penis, E: Tegmen and parameres. F: Apex of rostrum. G : Fore tibia. H : Apex of hind tibia. I : Distal segments of antenna.

Pagiophloeus cribripennis : Dalla Torre et Schenkling, 1932, Col. Cat,, 122: 21.

Hylobius cribripennis: Kôno, 1934, Journ.Fac. Agr., Hokkaido Imp. Univ., XXX111 (3) : 239

(Is. Hachijo) ; Morimoto, 1962, Bull. Gov. Forest Exp. Sta., (143) : 3; Nakane, 1963, Icon. Ins. Jap. Col. nat. ed., II: 367, pl. 184, fig. 12, 13.

Hylobius desbrochersi Zumpt, 1932, Kol. Rdsch., 18: 130 (new name for roelofsi Desbrochers, nec Harold, 1878) ; Kôno, 1934, Journ.Fac. Agr., Hokkaido Imp. Univ., XXX111 (3) : 239; Iga, 1955, Col. Ill. Ins. Jap.. Col. enlarged ed.: 220, pl. 68, fig. 1569; Chûjô \& Morimoto, 1956, Forest Prot. News, 5(10): 6 (biology); Matsuzawa \& Kawahara, 1957-58, Bull. Fac. Agr., Kagawa Univ., 8 (2) : 172, 9 (3) : 129 (biology, control) ; Matsuzawa \& Kawahara, 1957, Forest Prot. News, 6(5) : 9 (biology) ; Matsuzawa, Nogyo Kagawa, 10: 43, 46 (biology, control).

S Pecimens examined : 45 specimens from Is. Hachijo, Niigata (Senami, Kotaki), Nara (Kasuga), Nagano (Mt. Yatsugatake), Kyoto (Kurama), Is. Shodo-shima, Kochi (Jinzenji, Makiyama), Ehime (Matsuyama), Fukuoka (Fukuoka, Inunaki, Mt. Hikosan), Nagasaki (Yukinoura, Mt. Kompira), Ishigaki and Iriomote Isls.

Distribution: Japan (Honshu, Shikoku, Kyushu, Is. Hachijo, Is. Ishigaki and Is. Iriomote), China.

H OST TREES: Ligustrum japonicum, L. obtusifolium, Olea europaea, and Syringa vulgaris.

This species is considerably variable in the punctation and the tuberculation of the pronotum and elytra. Fresh specimens are often densely covered 


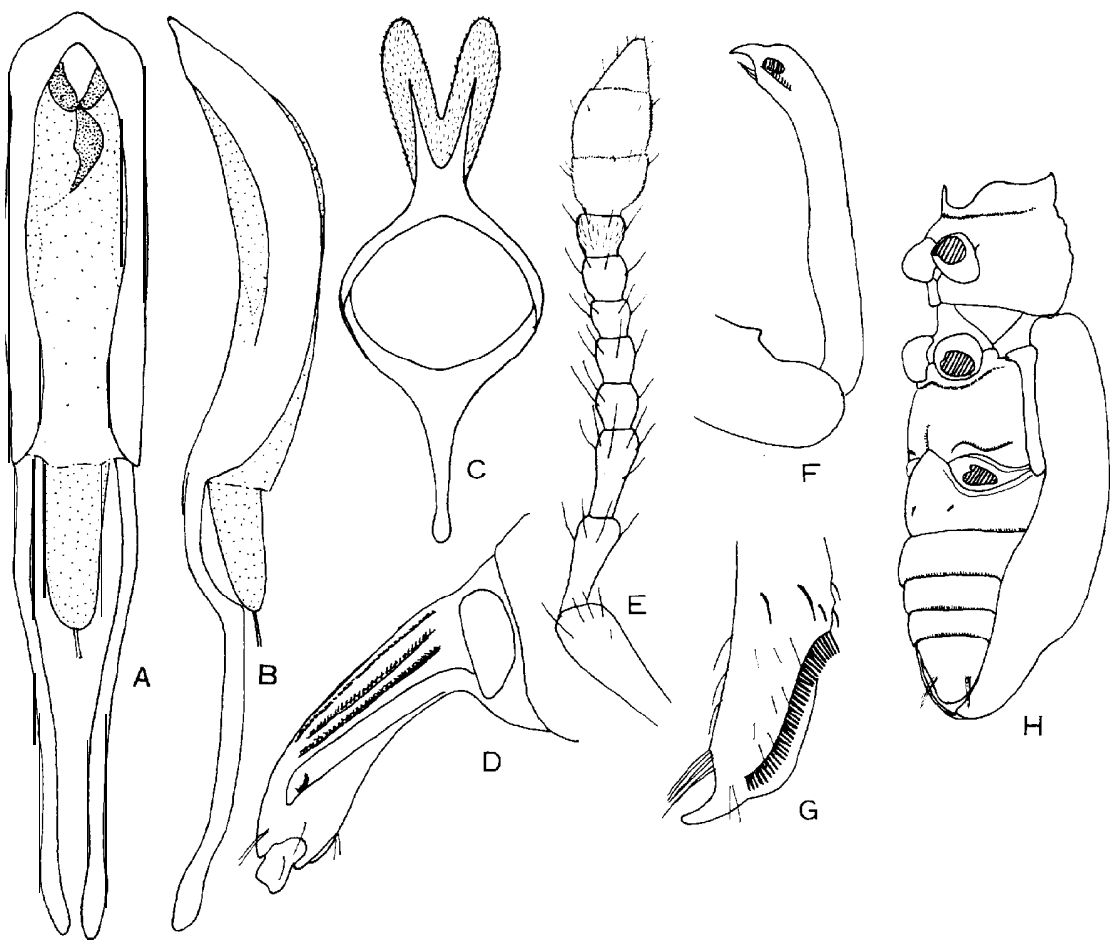

Fig. 23. Dyscerus laeviventris (Hustache), male. A: Penis, dorsal. B : Ditto, lateral. C: Tegmen and parameres. D: Head and rostrum. E: Antenna. F: Fore tibia. $\mathrm{G}$ : Apex of hind tibia. H : Latero-ventral aspect of body, showing hair tufts.

with white waxy powder on declivity and humeral area of elytra.

Dyscerus laeviventris (Hustache), comb. nov. (Fig. 23)

Hylobius laeviventris Hustache, 1920, Bull. Mus. nat. Hist. nat. Paris, (6) : 497 (Mt. Takao, Chuzenji, Tokyo, Alpes des Nikko) ; Kôno, 1934, Journ.Fac. Agr., Hokkaido Imp, Univ., XXX111 (3) : 232. Taf. V, fig. 2 (Honshu, Shikoku) ; Iga, 1955, Ill. Ins. Jap., Col. enlarged ed., 220, pl. 68, fig. 1568; Nakane, 1963, Icon. Ins. Jap. Col. nat. ed., II: 367, pl. 184 , fig. 8 .

Specimens examined : 35 specimens from Gunma (Mt. Hotaka, Sugenuma), Tochigi (Nikko), Yamanashi (Mt. Fuji, Daibosatsutoge), Tokyo (Mt. Takao), Nagano (Mt. Ontake, Ina, Mt. Kiso-Koma, Kamikochi, Mt. Yatsugatake, Mt. Nyugasa), Toyama (Unatsuki), Shizuoka (Mt. Amagi), Gifu (Mt. Ontake, Hirayu), Kochi (Kitagawa, Erimon), Tokushima (Mt. Tsurugi), and Oita (Mt. Sobo).

Distribution : Japan (Honshu, Shikoku, Kyushu) .

This species is very close to kanoi Kôno, 1933, from Taiwan. They are characteristic in having the impunctate and matt sternum and ventrites, and a pair of hairy tufts on the first ventrites in both sexes. The antennae and 


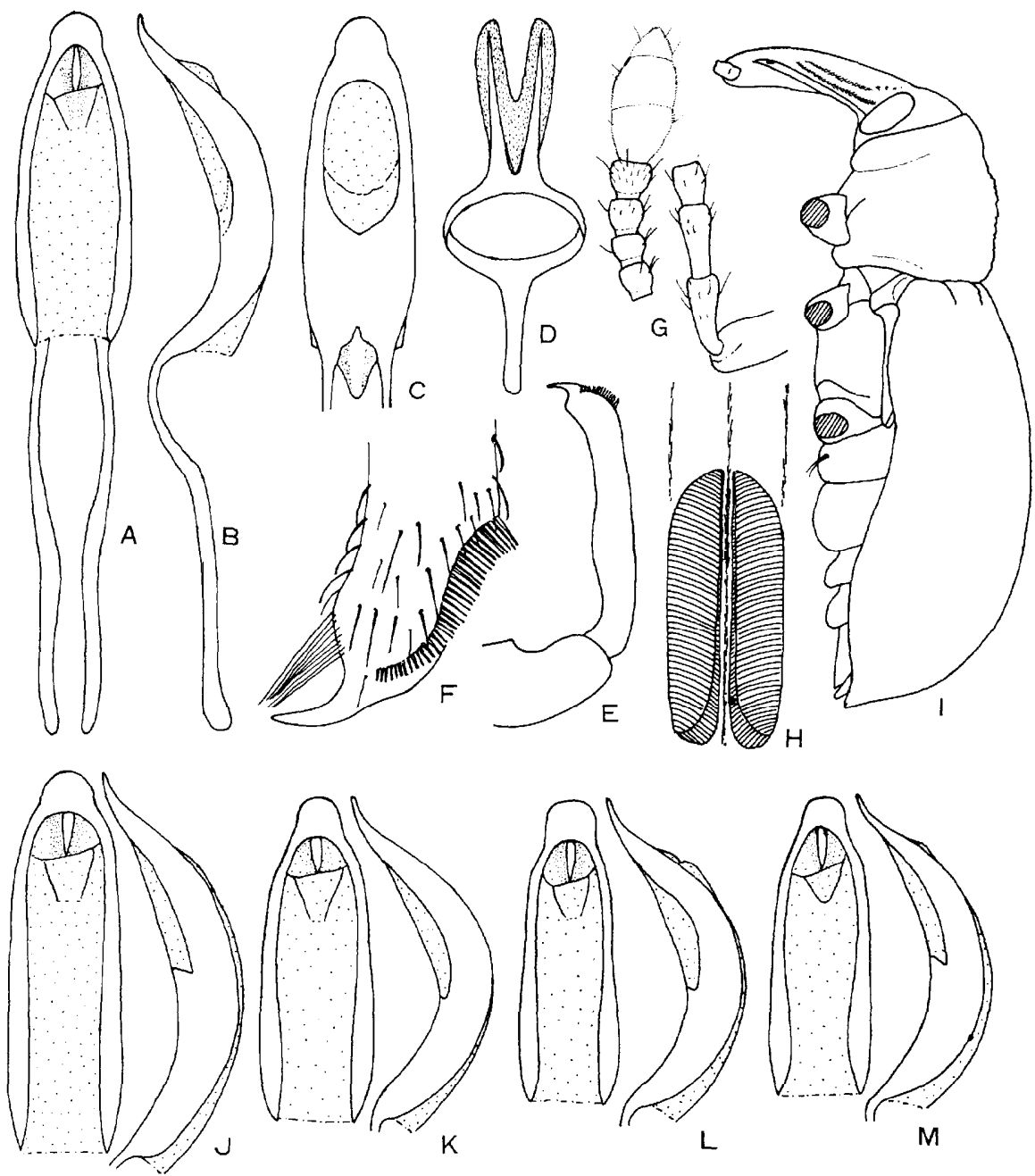

Fig. 24. Dyscerus roelofsi (Harold), male. A, B, J, K, L, M : Penis, dorsal and ventral. C : Ditto, ventral. D : Tegmen and parameres. E: Fore tibia. F : Apex of hind tibia. $\mathrm{G}$ : Antenna. H : Proventriculus. I : Body, lateral. (A- I : Onuma, J : Yukomanbetsu in Mt. Daisetsu, K : Atsumi in Yamagata Pref., L : Kifune in Kyoto Pref., M: Mt. Daisen in Tottori Pref. A \& J : Typical roelofsi; L \& M :oblongus of Kôno; K : Intermediate).

tibiae are slender and the tarsal grooves are strongly ascended. The penis has a crescent weak sclerite behind the ostium.

Dyscerus roelofsi (Harold), comb. nov. (Fig. 24)

Curculio Roelofsi Harold, 1878, Deut. Ent. Zeit., XXII : 84 (Hakodate).

Hylobius Roelofsi: Schoenfeldt, 1887, Jahrb. Nass. Vereins. Naturk., 40: 113 (Hakodate).

Okikuruminus roelofsi: Kôno, 1934, Journ.Fac. Agr., Hokkaido Imp. Univ., XXXIII (3) : 242

(Hokkaido, Is. Rishiri). 
Hylobius oblongus Hustache, 1920, Bull. Mus. nat. Hist. nat. Paris: 496 (Kioto, Yumoto, Kumanotaira, Chuzenji, Environ de Tokio, Yeso). Syn. nov.

Okikuruminus oblongus: Kôno, 1934, Journ.Fac. Agr., Hokkaido Imp. Univ., XXXIII (3) : 242 (Nikko, Chuzenji, Berg. Togakushi, Berg. Hakuba).

Specimens examined: 131 specimens from Hokkaido (Is. Rishiri, Nakatonbetsu, Piuka, Ashoro, Mt. Daisetsu, Onuma), Aomori (Oohata, Takada-Ohdake), Yamagata (Mt. Chokai, Atsumi spa), Iwate (Mt. Hayachine), Niigata (Mt. lide, Mt. Kitaeboshi, Mt. Ooishi, Mt. Monnai, Miomote, Kurokawa, Kamiishikawa, Ginzandaira, Sakasamaki, Mt. Amakazari, Yoshigahira, Mt. Yona, Mt. Shinbo, Mt. Takigawa, Takane, Akakura, Mikuni-toge, Sado), Fukui (Koike, Mt. Hakusan), Toyama (Mt. Tateyama), Fukushima (Yunohana spa), Tochigi (Nikko), Gunma (Ooshimizu, Oze), Nagano (Mt. Senjo, Mt. Kiso-Koma, Tobiratoge), Gifu (Gifu, Hirayu) Mie (Mt. Fujiwaradake), Kyoto (Kifune, Mt. Kurama, Hanazono), and Tottori (Mt. Daisen).

Distribution : Japan (Hokkaido, Honshu).

This weevil is considerably variable in size and coloration. The sepcimens from Hokkaido are black with two grayish scaly vague bands on elytra and generally larger. They have been identified as roelofsi. The specimens from central Honshu are a little smaller, more brownish at first sight due to the coloration of scales, which are a little more evenly scattered on elytra and the scaly bands are less distinct, and their legs are mostly reddish brown, as identified by Kôno (1934) as oblongus. The type-specimen of oblongus is labelled as "Japon, Kioto", but it is apparently a roelof $f_{s} i$ of the southern Hokkaido type. Many specimens of the Japanese Coleoptera were purchased by the Paris Museum from a dealer in Kyoto at that time and labelled as "Japon, Kioto". But they were apparently collected at least from Hokkaido, Honshu, Korea and Taiwan judding from the present knowledge of their distributions.

The specimens of roelofsi from Aomori, Akita, northern and mountainous regions of Niigata, and high mountains of I wate and Ishikawa Prefectures are the typical roelofsi. Several specimens from Yamagata (Oguni-machi), and Niigata (Mt. Shimbo, Mt. Takigawa, Shiroike, Is. A washima, Is. Sado) are of the roelofsi-type scaly coloration and pattern, but the basal parts of femora are more reddish.

Hylobius roelofsi and oblongus identified by Kôno (1934) are apparently the northern and southern populations of the same species, and the body size changes clinally smaller from north to south, and the colorations of legs and scales also change clinally at the northern and central part of Honshu. could not find out any difference between the northern and southern populations in the structures of aedeagus except for the size, which changes clinally smaller from north to south as in the body size.

H OST PLANTS: Adults are found on thistles. 


\section{Pagiophloeus Faust}

Pagiophloeus Faust, 1892 , Stett. Ent. Zeit., LIII : 195, 202; Heller, 1929, Abh. Zool. Mus. Dresden, XVII (3) : 12; Marshall, 1948, Novit. Zool., 42 : 399; Aslam, 1963, Bull. Brit. Mus. (Nat. Hist.), Ent., 13 (3) : 61. Type-species: Rhynchaenus pacca Fab., by original designation.

Dysceroides Kôno, 1933, Ins. Mats., VII: 187; Kôno, 1934, Journ.Fac. Agr., Hokkaido Imp. Univ., XXXIII (3) : 225, 240; Voss, 1958, Decheniana, Beihefte $5: 43$. Type-species : Dysceroides bipustulatus Kôno, by original designation. Syn. nov.

I have not seen the type-species of Pagiophloeus, and the definition is followed after Marshall (1948) and Aslam (1963). The following new species is similar to bipustulatus Kôno, javanicus Pascoe, and tuberosus Marshall.

Pagiophloeus tsushimanus sp. nov. (Figs. 25, 26)

Male. Black, antennae and tarsi dark reddish brown, with very sparse fulvous setiform scales above, which are a little denser and longer on the underside, punctures on the dorsal surface and parts on the undersurface covered with white or yellowish powder in various degree.

Head densely punctate, the punctures becoming smaller posteriorly, with a slight obtuse elevation in the middle, forehead between eyes flat, a little narrower than the base and as wide as the middle of rostrum, with a small median fovea. Rostrum as long as pronotum, rather stout, curved, slightly narrowed from base to just behind the antenna1 sockets, then dilated and parallel-sided near apex ; dorsum with large rugose punctures and five narrow irregular sinuous carinae, three median ones uniting close to the base, the lateral one extending up to forehead, apical margin with a small median projection. Antennae with scape clavate at apex, funicle with proportions in length from base as $20: 16: 6: 6: 6: 8: 9$, club $3 / 7$ times as wide as long, apical margin of first and second segments partly oblique to the axis of club.

Pronotum transverse, rounded laterally, widest at the middle, with a collar-like constriction at apex, postocular lobes distinct, gular margin deeply sinuate ; dorsum strongly convex longitudinally, with strong conical tubercles, with a strong median carina, posterior margin bisinuate.

Scutellum transverse (5:4), widest at the middle, lateral and posterior margins rounded, anterior margin weakly concave, punctate.

Elytra wider than the base of pronotum (10:9), widest at the shoulders, gradually narrowing posteriorly, apices each with a subconical process; striae with large punctures ; intervals narrow, uneven and very irregular, with a row of distant shiny granules, third interval with two oblong shiny tubercles, one a little behind the base and the other at the middle, fifth interval also with two tubercles, the anterior one at $1 / 4$ from the base small, the other on declivity subconical.

Legs stout, with sparse fulvous and white setae; femora strongly clavate, very rugose apically ; fore tibiae strongly curved at the base, then straight to 


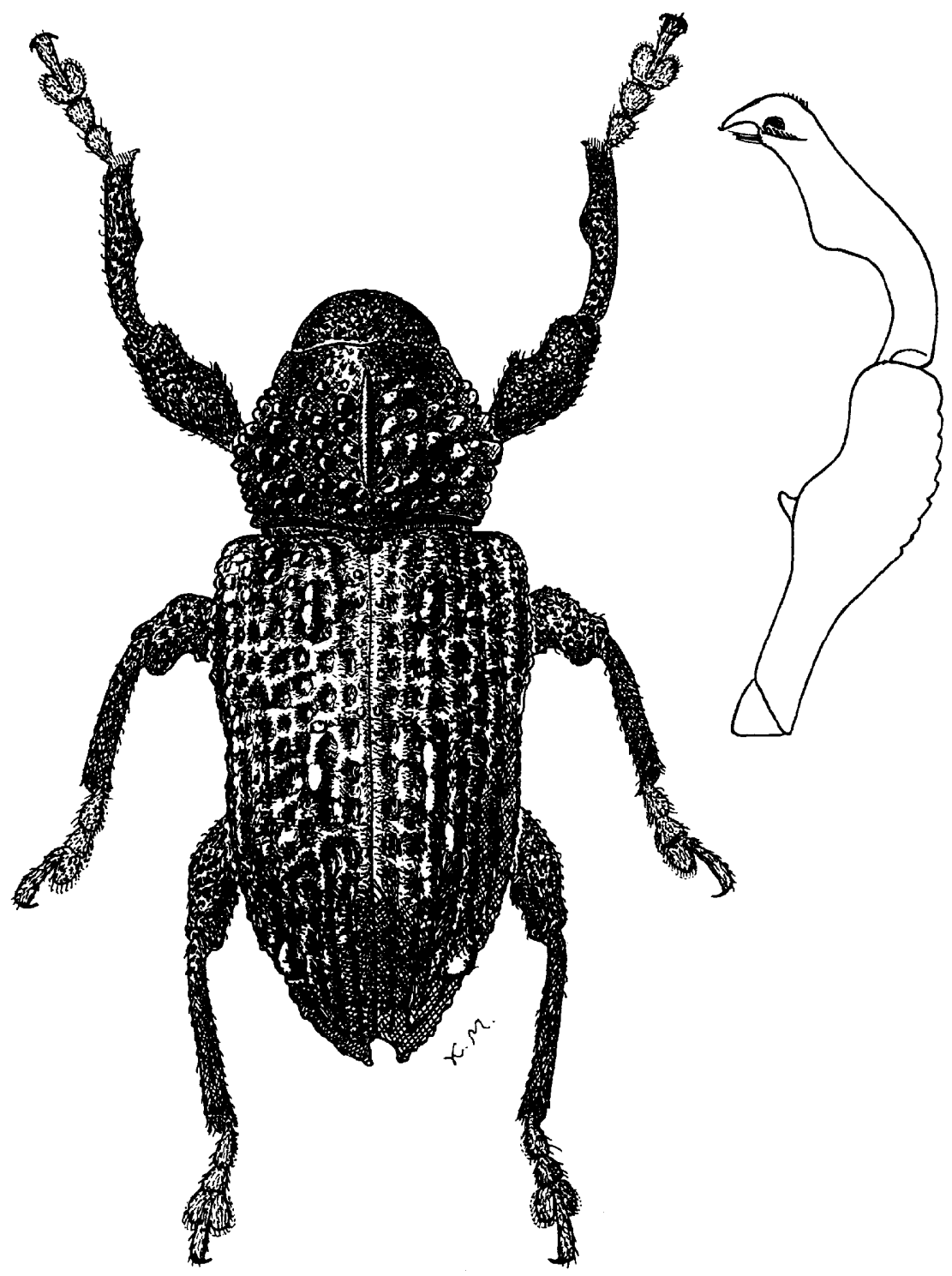

Fig. 25. Pagiophloeus tsushimanus sp. nov., male and fore leg.

the apex, with a very large subtriangular tooth in the middle internally; middle tibiae with a much small one, hind pair only obtusely expanded internally at the basal third. Hind tarsi with second segment $5 / 4$ times as wide as long.

Underside with coarse shallow subconfluent punctures at the sides of metasternum, which becoming sparser medially ; first ventrite weakly depressed in the middle, a little longer than the second behind coxa, with coarse shallow 

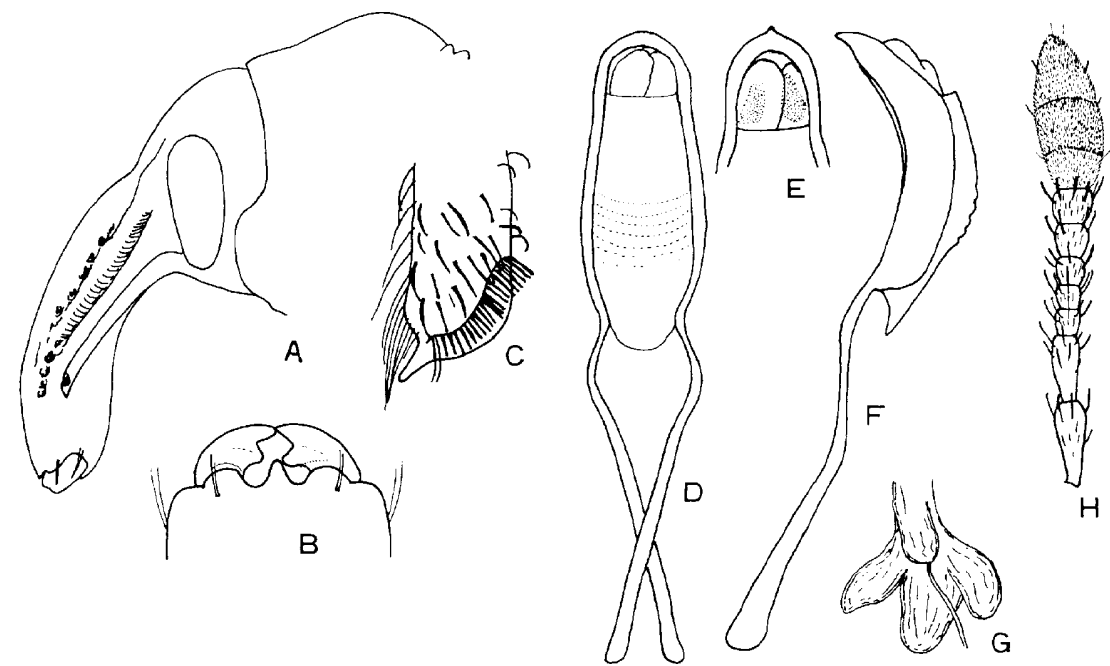

Fig. 26. Pagiophloeus tsushimanus sp. nov., male. A : Head and rostrum. B : Apex of rostrum. C : Apex of hind tibia. D : Penis, dorsal. E : Apex of penis. F : Penis, lateral. G : Internal sac, dorsal. $\mathrm{H}$ : Antenna.

subconfluent punctures, which being sparser laterally; second to fourth ventrites with shallow sparse punctures, fifth ventrite densely punctate.

Female. First and second ventrites evenly convex.

Length : 10.5-E. $2 \mathrm{~mm}$ (excl. rostrum) .

Holotype o (Type No. 2365, Kyushu Univ.), Azamo-Taterayama, Tsushima, 27. ix. 1959, T. Hidaka leg.

Paratypes: $\mathbf{2} \circ$, same data as holotype. Same locality as holotype, 10, 18. v. 1961, Y. Kimura leg.

Distribution: Japan (Tsushima).

Two specimens were captured on Cinnamomum camphora.

This new species is allied to bipustulatus (Kôno, 1933) from Taiwan, but bipustulatus differs in having two tubercles on each elytron, one on the third interval behind the base, and the other on the declivity of the fifth interval, and the general coloration is reddish according to the original description.

\section{Paramecops Schoenherr}

Paramecops Schoenherr, 1826, Disp. Meth. Curc.: 224; Schoenherr, 1836, Gen. Sp. Curc., III: 254; Schoenherr, 1843, Gen. Sp. Cm-c., VII (2) : 132; Lacordaire, 1863, Gen. Col., VI: 450, 456; Faust, 1892, Stett. Ent. Zeit., LIII: 202; Aslam, 1963, Bull. Brit. Mus. (Nat. Hist.), Ent., 13(3): 59. Type-species :Curculio farinosus Wiedemann, by original designation.

Paramecops granulatus sp. nov. (Figs. 27; 46 A)

Male. Dull black, with shiny granules and fulvous setiform recumbent scales, tarsi and antennae dark reddish brown. 

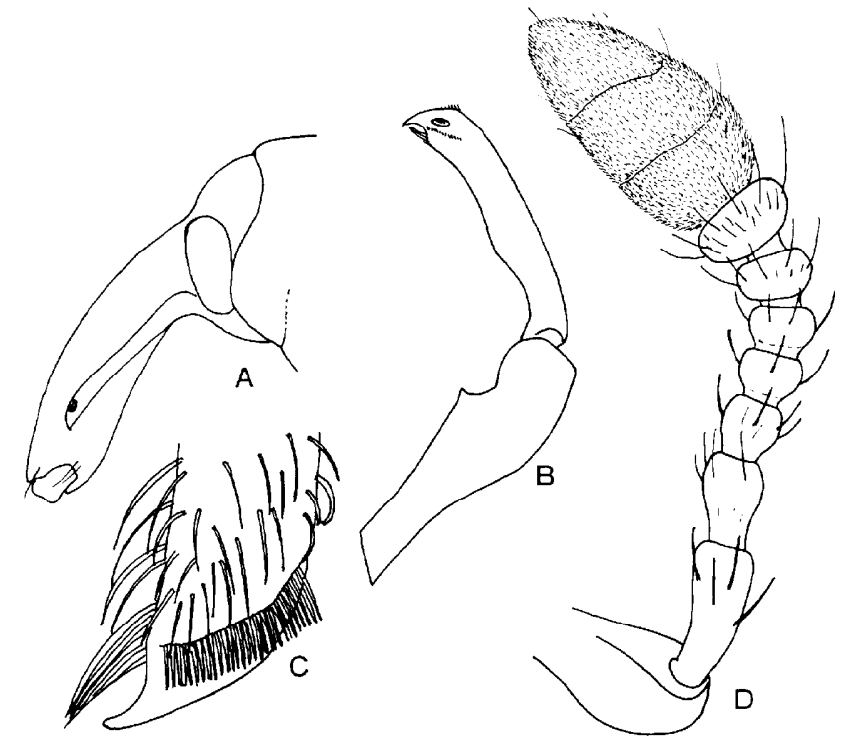

Fig. 27. Paramecops granulatus sp. nov., female. A : Head and rostrum. B : Fore tibia. C : Apex of hind tibia. D : Antenna.

Head with dense shallow punctures and a weak median elevation in the middle, forehead $2 / 3$ times as wide as the base of rostrum, with a median fovea. Rostrum about as long as pronotum, weakly and evenly curved, gradually narrowed from the base to the apical third. then dilated to the apex; dorsum with a weak median carina on basal two-thirds, punctures longitudinally confluent and forming three irregular sulci on each side, apical area between antenna1 sockets flat and densely punctate, almost impunctate along anterior margin. Antennae with scape clavate at apex, funicle with proportions in length from base as $15: 9: 6: 5: 5: 5: 6$, width of first 7 , seventh 11 , club compact, $7 / 12$ times as wide as long, first segment as long as the second, sutures partly oblique.

Prothorax $2 / 3$ times as long as wide, widest at basal third, postocular lobes well developed, gular margin deeply sinuate ; dorsum strongly granulate excepting the anterior margin, with a strong median carina, posterior margin bisinuate, with a shallow depression on each side before the third stria near the base.

Scutellum subcordiform, bare, impunctate, finely coriaceous.

Elytra parallel-sided from humeri to the apical third, each apex bluntly pointed ; intervals finely coriaceous, with a row of shiny granules, third interval a little higher than the others on basal half; striae with large punctures, interstices between the punctures on the same plane as intervals in the first and the basal area of second to fifth striae, the other area of interstices weakly convex and forming weak, small, shiny tubercles. 
Legs with femora weakly punctate on basal half and finely rugose apically, almost parallel-sided on basal half, each with a small tooth. Tibiae slightly curved at base, weakly bisinuate internally, tarsal groove oblique, not ascended. Tarsi with second segment a little wider than long.

Underside with ill-defined punctures, first ventrite between coxae depressed, with large punctures, first suture deeper on each side and convex anteriorly at the middle.

Female. Antennae inserted into rostrum as distant from the apex as its width.

Length : 9.0-10.2 $\mathrm{mm}$.

Holotype o (Type No. 2366, Kyushu Univ.), Mt. Takao, Tokyo, 11. vi. 1961, Y. Shibata leg.

Paratypes: Tanigawa, Gunma Pref ., 1ð, 3. vi. 1956, K. Morishita leg. Osawa, Oku-Nikko. Tochigi Pref., 1 ㅇ, 15. vi. 1969, N. Kino leg.

Distribution : Japan (Honshu).

This is the third species of the genus and easily separable from farinosus (Wiedemann) and wiedemanni Faust by the granulate pronotum and elytra, and the shape of the pronotum.

\section{Hesychobius Marshall}

Hesychobius Marshall, 1931, Ins. Samoa, IV (5) : 263. Type-species: Hesychobius nebulosus Marshall, by original designation.

Hybolius Chûjô et Voss, 1960, Mem. Fac. Liberal Arts \& Educ., Kagawa Univ., II (94) : 1;

Morimoto, 1962, Journ.Fac. Agr., Kyushu Univ., 12: 64. Type-species: Hylobius vossi Chûjô, by original designation. Syn. nov.

This genus was established by Marshall in the subfamily Erirhininae near Procas, but I transferred it to the Hylobiinae based on the fact that the tibiae are distinctly uncinate. The inner carina of the terminal surface of tibiae is sharply costate and from this carina the uncus arises.

Hesychobius vossi (Chujo), comb. nov. (Fig. 28)

Hylobius vossi Chûjồ, 1959, Niponius, I(1) : 1 (Cape Sata).

Hybolius vossi: Chûjô et Voss, 1960, Mem. Fac. Liberal Art. \&Educ. Kagawa Univ., 11(94): 1; Nakane, 1963, Icon. Ins. Jap. Col. nat. ed., II: 367, pl. 184, fig. 4 (Kyushu, Nakanoshima); Sawada \& Watanabe, 1969, Journ. Agr. Sci., Tokyo Univ. of Agr., 14: 34 (Is. Mikurajima) ; Watanabe \&Soma, 197`2, Journ. Agr. Sci., Tokyo Univ. of Agr., 17: 46 (Is. Miyake jimaj .

SPecimens examined: 59 specimens from Is. Mikurajima, Is. Aogashima, Kagoshima Pref. (Cape Sata), Is. Yakushima, Is. Kuroshima, Is. Amami-Oshima, Is. Nakanoshima, Is. Okinawa, Is. Ishigaki, Is. Iriomote, Taiwan (Mt. Shitoushan, Miaoli Hsien, 1ð, 24-26. v. 1980, H. Makihara leg.), Philippines (Baracatan, 1500 m, Mindanao, 1 우, 27-29. vi. 1977, M. Sato leg.), Thailand (Mae Klang Water Fall, 1ð, 11. vi. 1965, K. Morimoto leg.), and East Malaysia (Mananam, $50 \mathrm{~km}$ SW of Telupid, Sabah, $1 \precsim 1$ 우,5-9. viii. 1981, K. Morimoto 


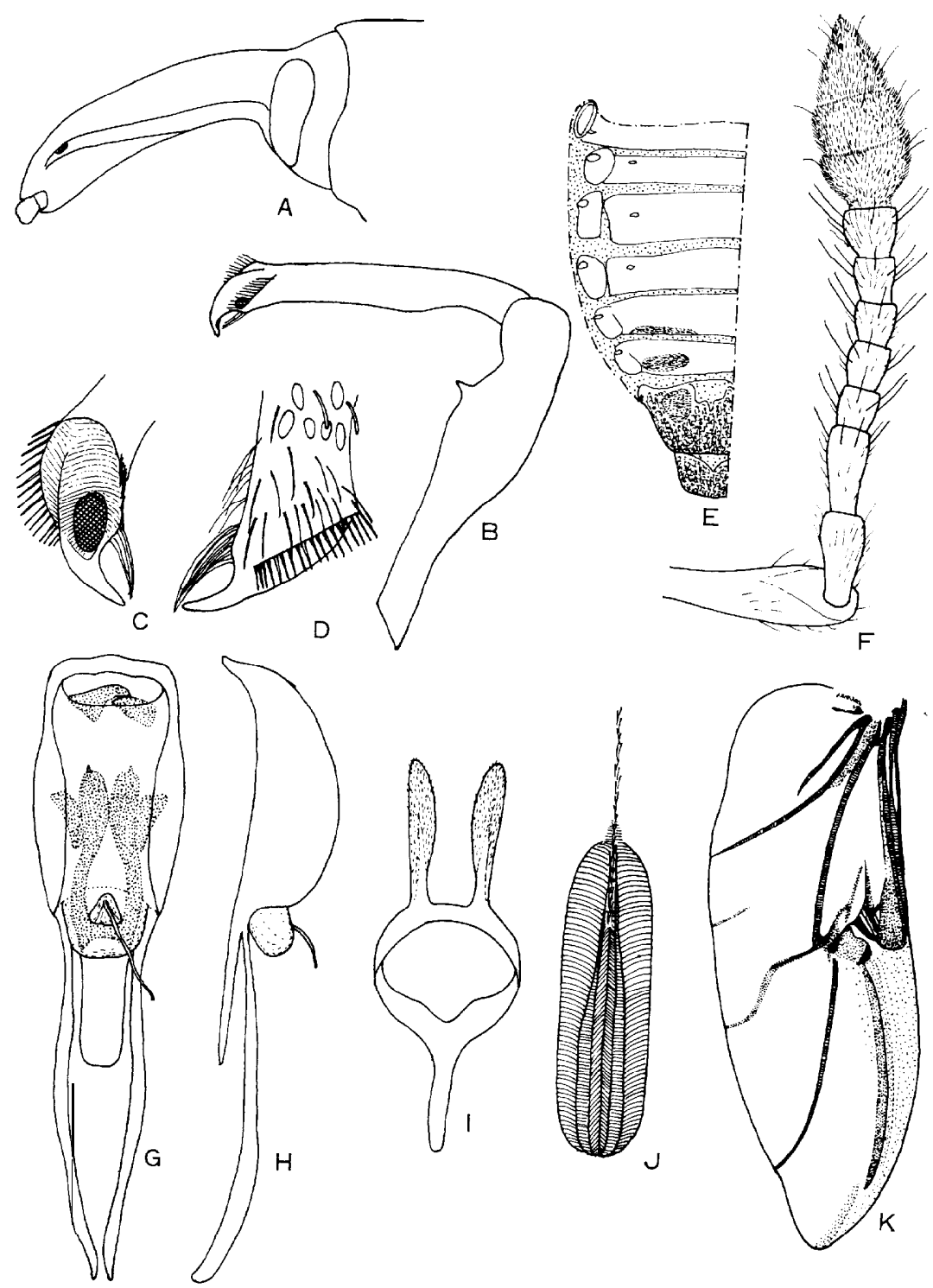

Fig. 28. Hesychobius vossi (Chûjô), male. A : Head and rostrum. B : Fore leg. C, D : Apex of hind tibia. E : Tergites. F: Antenna. G: Penis, dorsal. H : Ditto, leteral. $\mathrm{I}$ : Tegmen and parameres. J : Proventriculus. K : Hind wing.

leg.).

Distribution : Japan (Izu Isls., Kagoshima, Ryukyus), Taiwan, Philippines, Thailand and East Malaysia.

This species is very close to nebulosus Marshall from Samoa, but the forehead and rostrum are not scaled. 
Host trees are not confirmed. Adults are frequently captured by light trap at night, and also by beating the trees.

\section{Lepyrus Germar}

Lepyrus Germar, 1817, Mag. Ent., II: 348. Type-species: Rhynchaenus colon Fab., designated by Schoenherr, 1826 (=palustris Scopoli, 1763). See Dalla Torre et Schenkling, 1932, for synonymy.

Key to SPecies of the genus Lepyrus Germar in Ja pa n

1(2): Femora dentate, the tooth small and often concealed by erect scales; elytra each with a median $\wedge$-shaped greyish to yellowish band on fourth to sixth intervals $\ldots \ldots \ldots \ldots \ldots \ldots \ldots \ldots \ldots \ldots \ldots \ldots \ldots \ldots \ldots \ldots \ldots \ldots \ldots \ldots$ Lepyrus japonicus Roelofs

2(1): Femora edentate.

3(8): Pronotum weakly wrinkled-punctate; elytra with intervals not or weakly wrinkled, first stria half as wide as second interval.

4(5): Prothorax with subapical constriction well marked on lateral and ventral surface, postocular lobes well developed; antennae with second segment of funicle a little longer than the first; elytra usually with a median and subapical greyish sots

Lepyrus quadrinotatus Boheman

5(4): Prothorax with weak subapical constriction, postocular lobes weak.

6(7): Antennae with second segment of funicle a little shorter than the first; elytra with intervals flat, interstices between punctures of striae on the same level as intervals

Lepyrus nordenskioldi Faust

7(6): Antennae with second segment of funicle as long as or slightly longer than the first; elytra with intervals weakly convex, alternate ones more convex ...................................... Lepyrus nebulosus Motschulsky

8(3): Pronotum uneven, very strongly wrinkled punctate-granulate, with distinct postocular lobes, subapical constriction well marked on lateral and ventral surface; elytra with intervals granulate, punctures in striae strong, first stria nearly as wide as second interval.

9(10): Elytra with two pairs of greyish spots, one on the fourth interval just before the middle and the other on declivity; penis gradually narrowing anteriorly. Siberia and Sakhalin

Lepyrus arcticus Paykull

10(9): Elytra typically with three pairs of yellowish spots, one on fourth interval at basal third, one on sixth interval at the middle, the other on declivity, lateral itervals usually with several indistinct spots of the same colour; penis parallel-sided

Lepyrus flavipunctatus Zumpt

\section{Lepyrus japonicus Roelofs (Fig. 29, A-F)}

Lepyrus japonicus Roelofs, 1873, Ann. Soc. Ent. Belg., XVI. 186 (Hiogo); Faust, 1882, Deut Ent. Zeit., XXVI: 273 (Amur); Faust, 1887, HoraeSoc. Ent. Ross., XXI: 28 (Korea); Matsumura, 1907, Thous. Ins. Jap. IV: 13, pl. 56, fig. 3 ; Kleine, 1918, Ent. Blätt., XIV : 260 (Stridulation organ) ; Okamoto, 1924, Ins. Fauna Querpart Is., I(2) : 187 ; Matsumura, 1931, Ill. Common Ins. Jap., III: 112, 116, pl. 26, fig. 11 (Hokkaido, Honshu) ; Matsumura, 1931, 6000 Ill. Ins. Jap. Emp.,: 287, fig. 943; Yuasa, 1932, Icon. Ins. Jap., : 541, fig. 1056; Kato, 1933, Bunrui Genshoku Konchu Zukan, 9, pl. 21, fig. 3; Kamiya \& Adachi, 1933, Genshoku KochuZufu, p!. 47, fig. 31; Haku, 1936, Journ. Chosen Nat. Hist. Soc., 21: 122 (Korea); Zumpt, 1936, Publ. Mus. Ent. "Pietro Rossi”, XIV: 27 (Amur, China, Korea, Japan: Jokohama) ; Kôno et Kim, 1937, Journ. Chosen Nat. Hist. Soc., 22: 20 (Siberia, China, Korea, Honshu) ; Hirayama, 1940, KochuZufu: 75, pl. 28, fig. 31; Kôno, 1950, Icon. Ins. Jap.: 1264, fig. 3640 (Hokkaido, Honshu) ; Iga, 


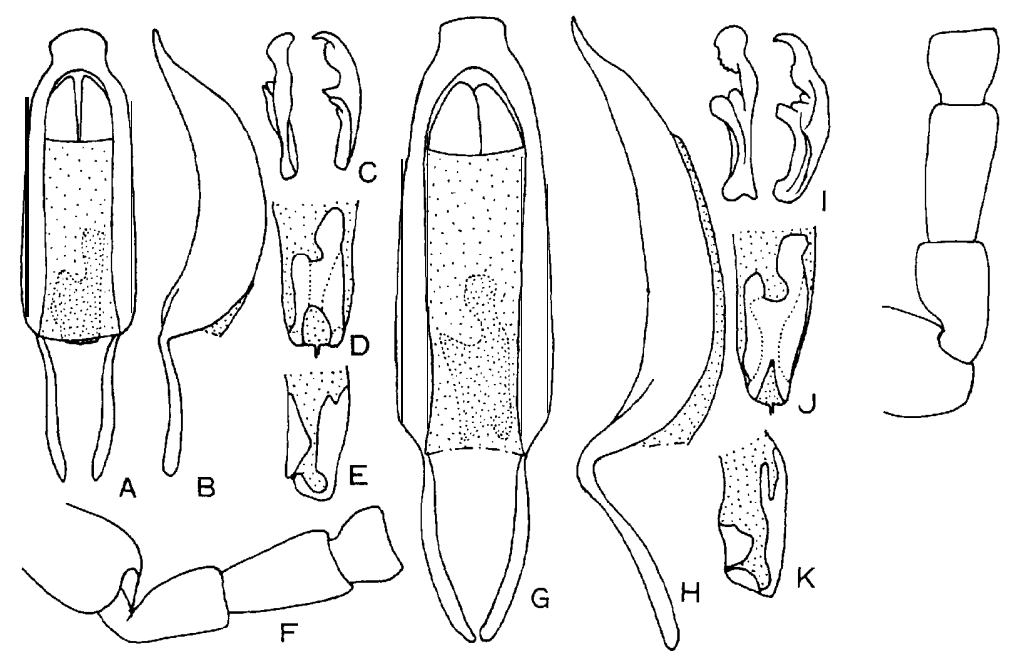

Fig. 29. Lepyrus spp. A-F : japonicus Roelofs. A : Penis, dorsal. B : Ditto, lateral. C : Sclerite of gonopore. D : Internal sac, dorsal. E : Ditto, lateral. F : First to third segments of antennal funicle. G-K :nebulosus Motschulsky. G: Penis, dorsal. H : Ditto, lateral. I : Sclerite of gonopore. J : Internal sac, dorsal. K : Ditto, lateral. L : quadrinotatus Boheman, first to third segments of antennal funicle.

1966, Col. Ill. Ins. Jap., Col., enlarged ed.: 221, pl. 68, fig. 1572; Nakane, 1963, Icon. Ins. Jap. Col. nat. ed., II: 367, pl. 184, fig. 1; Chao \& Chen, 1980, Econ. Ins. Fauna China, 20: 107, pl. VII, fig. 74 (China, Siberia, Korea. Japan ; biology).

SPECIMEN examined : 22 specimens from Hokkaido (Antaroma), Aomori (Aomori), Yamagata (Kamabuchi), Niigata (Sasaguchihama, Kurokawa, Nakajo), Nagano (Shimashimadani), Gifu (Oogaki), Mie (Misugi), Fukuoka (Mt. Adachi, Kurate, Akama), Kumamoto (Kikuchisuigen), and China (Peking).

Distribution : Japan (Hokkaido, Honshu, Kyushu), Korea, China, Siberia.

Host TREES : Salix spp.

This species is characteristic of the scaly spots on elytra. 'The aedeagus is relatively small, the apex of penis is rather broader, parallel-sided for a short distance and weakly rounded at the apex.

Lepyrus flavipunctatus Zumpt (Figs. 30; $46 \mathrm{~F}$ )

Lepyrus arcticus:Kô n 0 (nec Paykull), 1936, Biogeogr., ((2) : 98 (Berg Daisetsu).

Lebyrus flavipunctatus Zumpt, 1936, Ins. Mats., X: 146 (Berg Daisetsu).

Specimens examined: Mt. Daisetsu, Hokkaido, $1 \precsim 1$ \% , 8. vii. 1927, H. Kôno leg. (ð: holotype) ; 1 ॠ우, 28. vii. 1952, T. Yoshida leg. ; $1 \precsim 1$ 우, 17. vii. 1961, Y. Kuroda leg., 1 우, 18 vii. 1961, Y. Komiya leg.

Distribution : Japan (Hokkaido : Mt. Daisetsu).

This species was described on one male from Koizumidake in Mt. Daisetsu. This is very close to arcticus (Paykull), but the male is a little slenderer. The penis of holotype is slightly deformed and the ventral outline is angulate 


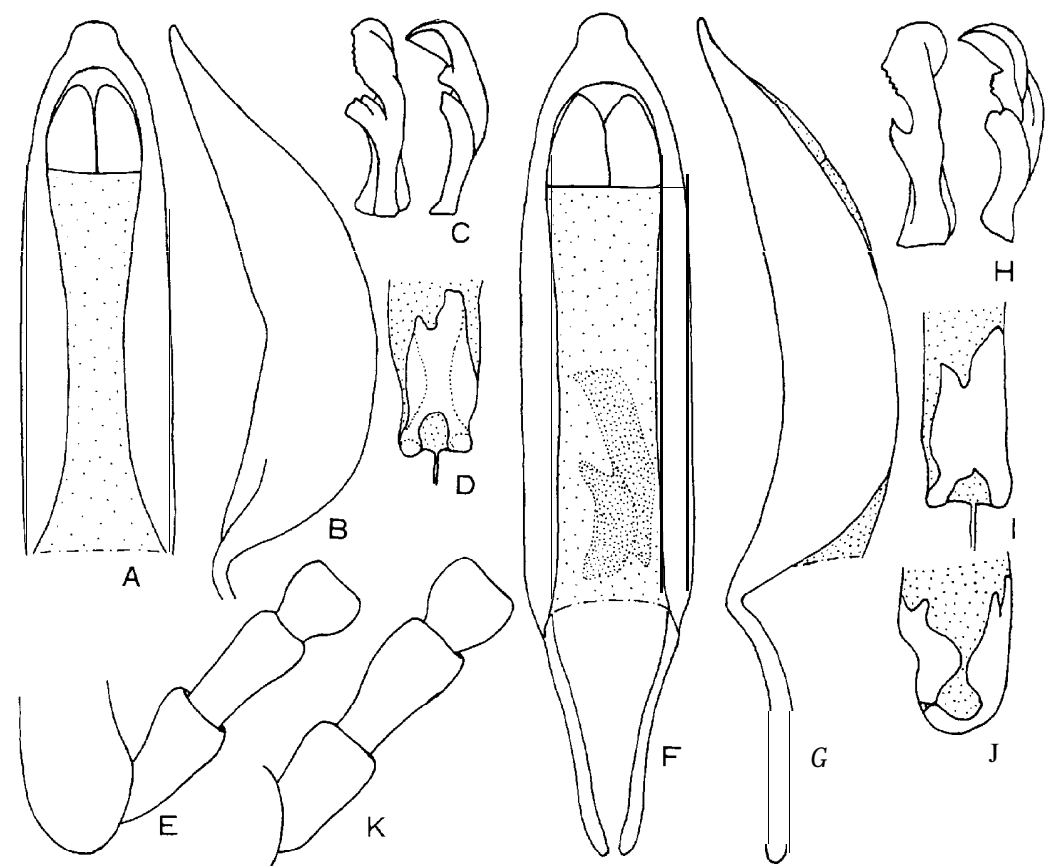

Fig. 30. Lepyrus flavipunctatus Zumpt, male. A, F : Penis, dorsal. B, G : Ditto, lateral. C, H: Sclerite of gonopore. D, I : Internal sac, dorsal. J : Ditto, lateral. E, K : First to third segments of antennal funicle. (A-E : Holotype; F-K : Hakuundake in Mt. Daisetsu).

at the middle in profile. The penis of the other males is similar to that of costulatus Faust as illustrated by Zumpt. It is parallel-sided on basal twothirds, the apical prominence is parallel-sided for a short distance and evenly rounded at apex. In arcticus from Sakhalin, the penis is gradually dilated posteriorly and the apical prominence is weakly narrowing anteriorly for a short distance and rounded at apex.

\section{Lepyrus nordenskioldi Faust (Fig. 31, A-F)}

Lepyrus nordenskioldi Faust, 1885, in Sahlberg, Vega Exped. Vet. Iakt., IV: 34 (Tschuktsch. landet); Van Dyke, 1928, Pan-Pacific Ent., V: 55, 56 (Alaska) ; Zumpt, 1936, Publ Mus. Ent. "Pietro Rossi”, XIV: 8, 22 (Ostsibirien, Mandschurei) ; Korotyaev, 1976, Trud. Zool. Inst., LXII: 45 (Kamchatka); Egorov, 1977, in Skariato at al., Syst. Faun. Ins. (Zool. Inst. Acad. Nauka SSSR): 35 (Siberia).

Specimens examined : Mt. Daisetsu, Hokkaido, 1우, 31. vii. 1952, T. Yoshida leg. ;1우, 2. vii. 1955, Y. Murakami leg.;1우, 1. vii. 1961, Y. Komiya leg. Mt. Tomuraushi, Hokkaido, 1ð2,28. vii. 1973, A. Abe leg.

Distributron : Japan (Hokkaido), East Siberia, North Eastern China, Alaska. 


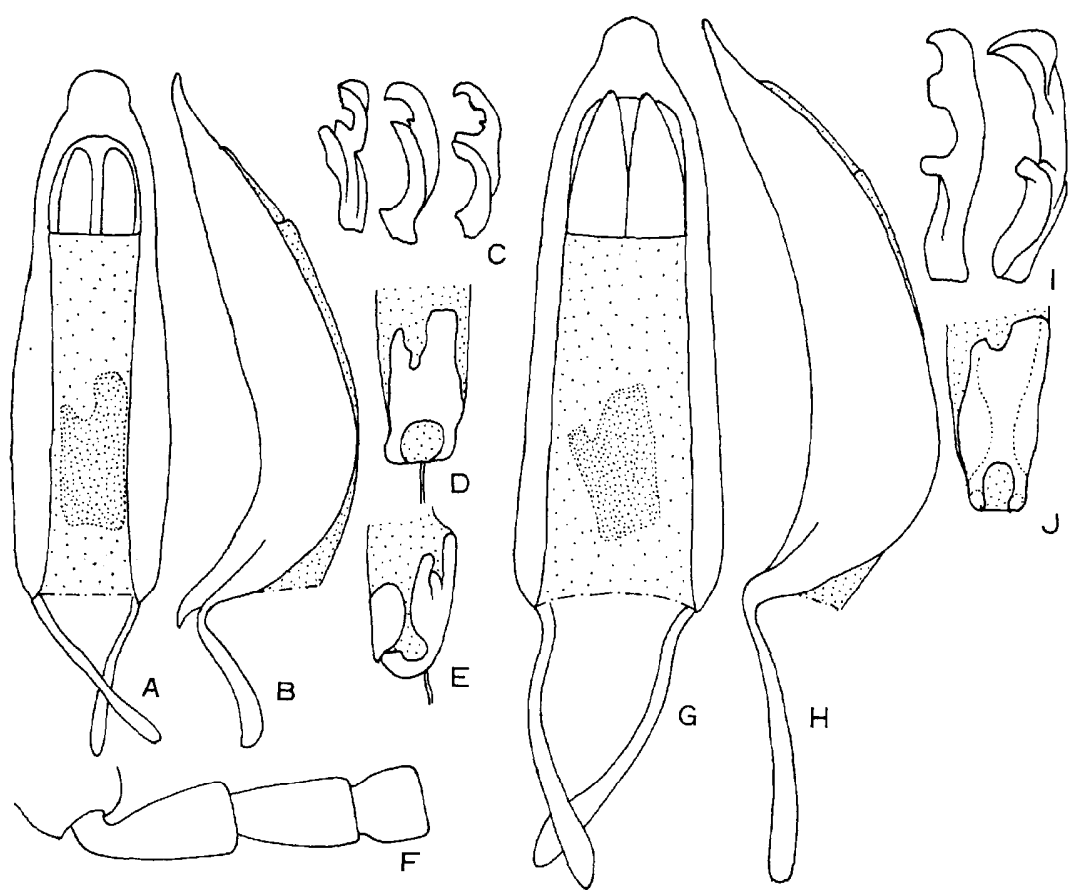

Fig. 31. Lepyrus spp. A-F : nordenskioldi Faust. G- J : arcticus (Paykull), from Sakhalin. A, G : Penis, dorsal. B, H : Ditto, lateral. C, I : Sclerite of gonopore. D, J : Internal sac, dorsal. E : Ditto, lateral. F : First to third segments of antennal funicle.

\section{Lepyrus nebulosus Motschulsky (Fig. 29, G-K)}

Lepyrus nebulosus Motschulsky, 1860, Schrenck's Reisen Amurl., II: 165, Tab. X, fig. 18 (sur les rivages meridionaux de fl. Amour); Faust, 188'2, Deut. Ent. Zeit., XXVI: 270 (Albasin, Raddefka, Ussuri) ; Zumpt, 1936, Publ. Mus. "Pietro Rossi”, XIV: 8, 23 (Ostl. Siberia, Mandschurei, China); Chao \& Chen, 1980, Econ. Ins. Fauna China 20: 107, pl. VII, fig. 75 (China, Siberia) ; Hirano, 1981, Beetles of Kanagawa Pref.: 368 (Odawara, Hakone). Egorov, 1977, in Skariato et al, Syst. Faun. Ins. (2001. Inst., Acad. Nauka SSSR) : 35 (Siberia).

Lepyrus nordenskioldi: Nakane (nec Faust), 1963, Icon. Ins. Jap. Col. nat. ed., II: 365, pl. 183, fig. 2 (Hokkaido, Honshu).

Spectmens examined : Natsudomari, Moura Coast, Aomori Pref., $2 \precsim 1$ ㅇ, I. Hiura leg. Toride, Ibaragi Pref., 1ð, 29. ix. 1956, K. Tanaka leg. Atagoyama, Kofu City, Yamanashi Pref., $10^{\jmath}$ ㅇ, 15. vii. 1956, H. Kamiya leg. Kario, Aso, Kumamoto Pref., 18, 10. vi. 1979, I. Otsuka leg.

Distriburion : Japan (Hokkaido, Honshu, Kyushu), Siberia, and China.

\section{Lepyrus quadrinotatus Boheman (Fig. 29, L)}

Lepyrus quadrinotatus Boheman, 1842, in Schoenh., Gen. Sp. Curc., VI (2) : 295 (Irkutsk) ; Zumpt, 1936, Publ. Mus. Ent. "Pietro Rossi", XIV: 8, 20 (Ostl. Siberien, Altai) ; Egorov, 
1977, in Sakariato et al., Syst. Faun. Ins. (Zool. Inst., Acad. Nauka SSSR): 35 (Siberia) ; Nakane, 1963, Icon. Ins. Jap. Col. nat. ed., 367, pl. 184, fig. 2 (Hokkaido).

Lepyrus arcticus var. 4-notatus: Faust, 1882, Deut. Ent. Zeit., XXVI: 271 (Lappland, Baical, Kjachta, Daurien, Ussuri).

Lepyrus arcticus ab. quadrinotatus: Csiki, 1934, Col. Cat., 134: 5.

SPecimens EXAmined : Mt. Daisetsu, Hokkaido, 1우 6. viii. 1926, H. Kôno leg. Mt. Ashibetsudake, Hokkaido, 1우, 20. viii. 1961, S. Uéno leg. Keton, Saghalien, 1 우, 27. vii. 1932, H. Kôno leg.

Distribution : Japan (Hokkaido), Lappland, Siberia, Sakhalin.

\section{Euthycus Pascoe}

Euthycus Pascoe, 1887, Ann. Mus. Genova, (2): II: 220; Faust, 1893, Stett. Ent. Zeit., LIV:

13 ; Morimoto, 1962, Journ.Fac. Agr., Kyushu Univ., 12 : 64. Type-species: Euthycus macilentus Pascoe, by monotypy.

Euthicus Heller, 1922, Deut. Ent. Zeit.: 10.

Euthycus japonicus Heller (Figs. $32 ; 47$ A)

Euthicus japonicus Heller, 1922, Deut. Ent. Zeit., 11, 12 (Japonia septentrionali) ; Heller, 1931, Wien. Ent. Zeit., 48: 100.

Euthycus japonicus: Dalla Torre et Schenkling, 1932, Col. Cat., 122: 66.

Dull black, antennae and tarsi reddish brown to blackish brown, with
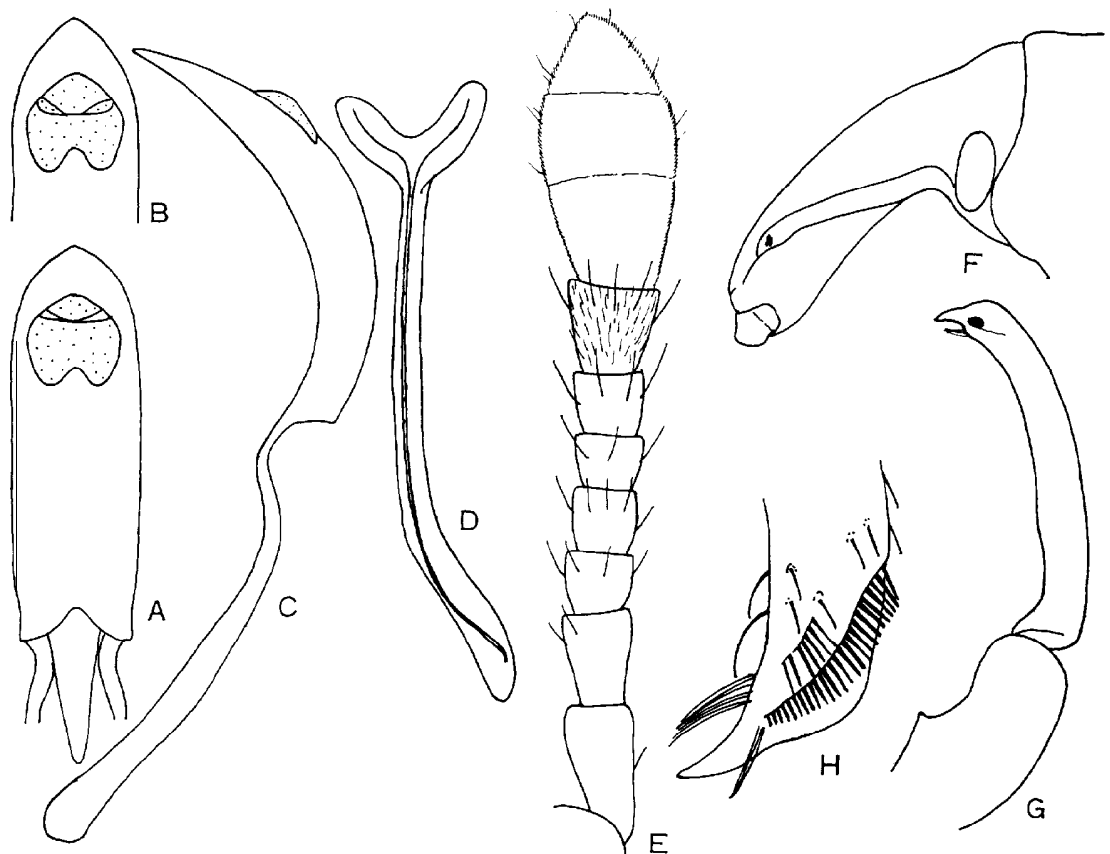

Fig. 32. Euthycus japonicus Heller, male. A : Penis, dorsal. B : Ditto, apex. C : Ditto, lateral. D : Ninth sternite. E: Antenna. F: Head and rostrum. G: Fore tibia. $\mathrm{H}$ : Apex of hind tibia. 
very sparse minute fulvous scales in the punctures of legs and the underside. and on granules of elytra.

Head with small dense punctures; forehead as wide as the base of rostrum, with a deep median fovea; eyes almost flat. Rostrum with irregular large punctures, with a trace of median and a pair of lateral carinae, dilated apical part punctulate, median longitudinal fovea between antenna1 insertions deep. Antennae with seventh segment of funicle trapezoid in outline.

Pronotum a little longer than wide, evenly rounded laterally, widest before the middle, dorsum uneven, with very rugose punctures, some of the interstices s\&granulate, with a fine median irregular carina on apical two-thirds.

Elytra scarcely wider than pronotum at base, sides slightly rounded and widest in the middle, punctures in the striae ill-defined, third and fifth intervals convex with dense granules, the other intervals each with a row of sparse granules, conjoint parts of second and tenth, and third and ningh intervals subtuberculate.

Femora with a small tooth, tibiae curved inwards.

Penis well sclerotized, parallel-sided, triangular at tip.

Length : 9.5-10.0 mm (excl. rostrum).

Specimens examined: Yuwan, Amami-Oshima, 1우, 5. iv. 1958, M. Takahashi leg. Mt. Yuwandake, Amami-Oshima, 1ð1, 16-18. vii. 1963, M. Yoshimoto leg.; 2ㅇ, 30. vii. 1963, L. Gressitt leg.; 1우, 6. viii. 1963, T. Okada leg. Sumiyo, Amami-Oshima, 1ठ, 9. viii. 1963, T. Okada leg.

Distribution : Japan (Is. Amami-Oshima) .

Euthycus inaequalicollis sp. nov. (Fig. 33)

Male and female. Dull black, antennae and tarsi reddish brown, with very sparse minute fulvous scales; legs and underside with very sparse fulvous setae.

Head with dense small punctures; forehead as wide as the base of rostrum, with a small median fovea; eyes weakly convex, being less convex than temples. Rostrum robust, $2 / 3$ times as long as pronotum, with large irregular rugose punctures above between apical third and forehead leaving median and a pair of fine carinae, the dorsal outline slightly concave at basal third and at base, dilated apical part glossy with small punctures and with a median deep sulcus. Antennae with second segment of funicle shorter than the first, third to seventh segments each transverse.

Prothorax a little longer than wide, widest before the middle, the sides weakly rounded, subapical constriction obsolete on pronotum, postocular lobes well marked, posterior margin weakly bisinuate; disk uneven, with rugose punctures, with a fine median carina. Scutellum obsolete.

Elytra scarcely wider at the base than pronotum, almost parallel-sided or very slightly rounded to the middle from the base, then rounded to the sub- 


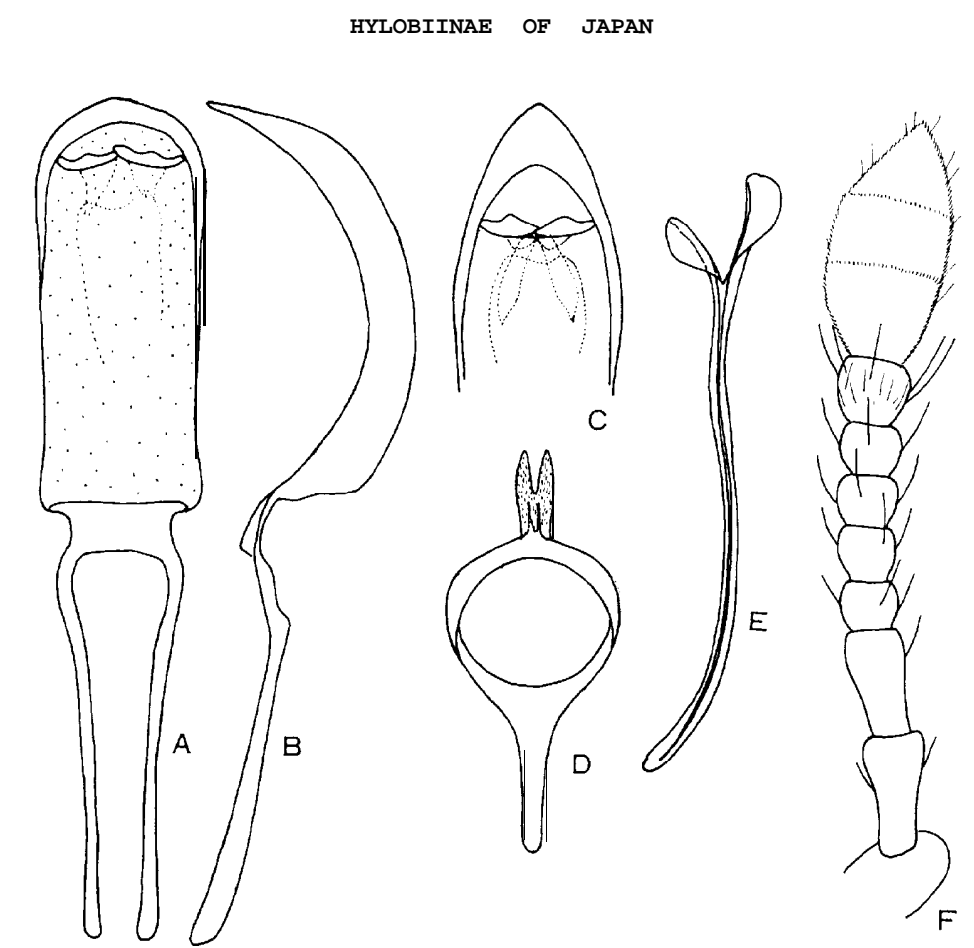

Fig. 33. Euthycus inaequalicollis sp. nov. A : Penis, dorsal. B : Ditto, lateral. C : Apex of penis. D: Tegmen and parameres. E : Ninth sternite, F: Antenna.

apical constriction, widest behind the middle, parallel-sided for a short distance from the subapical constriction posteriorly and jointly rounded at apex, which is produced downwards in both sexes; dorsum weakly convex and the posterior declivity gentle ; striae with sparse and small punctures, first stria with about ten punctures, interstices between punctures and intervals uneven, the latter a little wider than the puncture, third and fifth intervals costate at base, first to third intervals tuberculate at apex, fifth interval weakly tuberculate at declivity, granules obsolete or sparse.

Legs with shallow subconfluent punctures; femora dentate ; tibiae curved inwards at apex, weakly dilated internally at basal third.

Aedeagus with penis rather flat, strongly curved, dorsal surface less sclerotized.

Length : 6.4-8.3 $\mathrm{mm}$ (excl. rostrum).

Holotype ${ }^{\Uparrow}$ (Type No. 2367, Kyushu Univ.), Okinawa, VII. 1960, S. Kuniyoshi leg.

Paratypes:Is. Ishigaki, $1 \delta^{\star}, 1933$, Masaki leg. Hungyeh Wenchuan, Hualien Hsien, Taiwan, 1ㅇ, 13. vi. 1976, H. Makihara leg.

Distriburton: Japan (Okinawa and Ishigaki Isls.), Taiwan.

This new species is close to japonicus Heller, but can be separable from it by the following points.

Body smaller; third and fifth intervals of elytra costate at base; granules 
almost obsolete on elytra; antennae with third to seventh segments of funicle more globular; and penis flat and more curved.

\section{Kyliparus gen. nov.}

Type-species : Molytes Zewisii Roelofs, 1873

(Ky:Initials of Prof. Emeritus Keizo Yasumatsu + Liparus)

Head globular; eyes pear-shaped and acuminte below, as widely separated beneath as above; forehead between eyes narrower than the base of rostrum, with a median fovea. Rostrum robust, weakly curved, malar setae close behind mandibles; mentum and postmentum each with a pair of long setae. Antennae with scape as long as funicle, first segment of funicle as long as the second, third to seventh segments each nearly as long as wide, club with first segment shorter than the rest, sutures rectangular to the axis.

Pronotum truncate at the base, weakly sinuate at the gular margin, postocular lobes weak. Scutellum semicircular.

Elytra without shoulders, seventh and eighth striae reaching the base, tenth stria entire.

Femora clavate, dentate; hind femora not reaching the apex of elytra. Tibiae nearly straight, strongly uncinate at apex, outer setose fringe of hind corbel ascending the dorsal margin and longer than the width of tibia. Tarsi with third segment bilobed, claws simple, free.

Fore coxae contiguous; metasternum shorter than the first ventrite behind coxa; metepisterna distinct; venter with the intercoxal process narrower than coxa, suture behind first ventrite deeper on each side.

Genera of the Hylobiinae close to this new genus are separable by the key given below.

1(6) : Scutellum present.

$Z(3)$ : Hind femora reaching the apex of elytra ; metepisterna linear

Apterylobius Marshall

$3(2)$ : Hind femora not reaching the apex of elytra ; metepisterna broader.

4(5): Seventh funicular segment annexed to club; tibiae serrate internally ......

Liparus Olivier

5(4): Seventh funicular segment free from club; tibiae not serrate

Kyliparus gen, nov

6(1): Scutellum absent; forehead between eyes narrower than the base of rostrum ; scrobes widely separated throughout ...................... Euthycus Pascoe

Kyliparus lewisii (Roelofs), comb. nov. (Figs. 34; 46 E)

Molytes Lewisii Roelofs, 1873, Ann. Soc. Ent. Belg., XVI: 178 (Hiogo).

Liparus Lewisi: Dalla Torre et Schenkling, Col. Cat., 122: 55.

Liparus lewisi: Kôno, 1934, Journ.Fac. Agr., Hokkaido Imp. Univ., XXXIII (3) : 243.

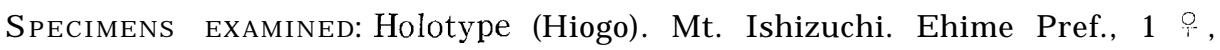
26. vii. 1948, Tornari leg.

Distribution : Japan (Honshu, Shikoku). 


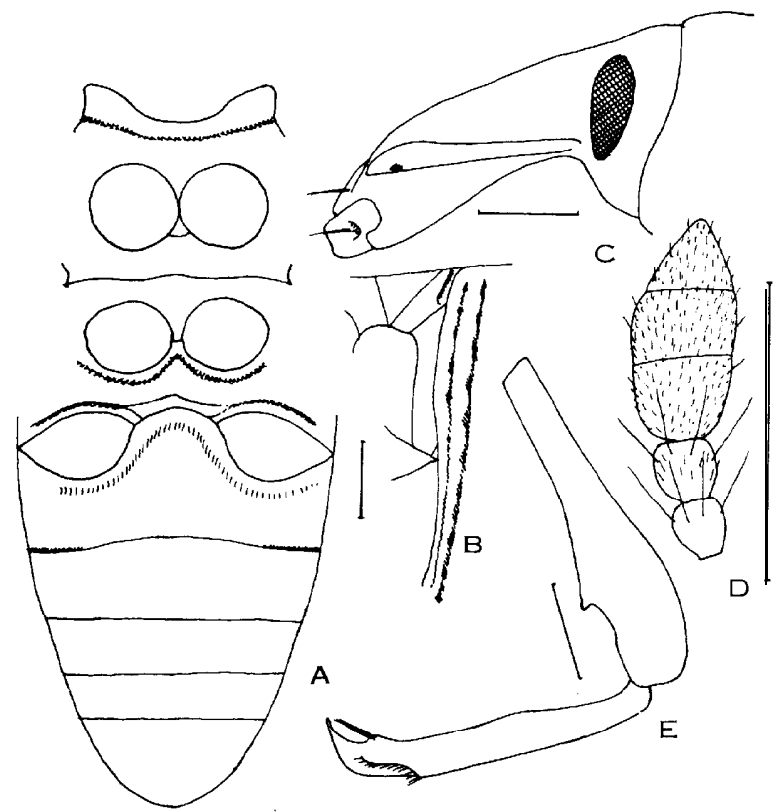

Fig. 34. Kyliparus lewisii (Roelofs), holotype. A: Underside of body. B : lateral pieces of meso- and metathorax. C: Head and rostrum. D: Distal segments of antenna, E : Hind leg. (scale : $1 \mathrm{~mm}$ ).

Tribe Plinthini

Subtribe Plinthina

Metahylobius Nakane

M etahylobius Nakane, 1964, Sci. Rep. Kyoto Pref. Univ., 15 A: 37. Type-species: Metahylobius jonensis Nakane, by monotypy.

Metahylobius jonensis Nakane (Figs. 35; $47 \mathrm{~B}$ )

Metahylobius jonensis Nakane, 1964, Sci. Rep. Kyoto Pref. Univ., 15 A: 37 (Mt. Jonen, 1900 m alt.).

Metahylobius jonensis autumnalis Nakane, 1964, ibid., 15A: 37 (Mt. Jonen, $1900 \mathrm{~m}$ alt.).

Specimens examined: Mt. Shiroumadake, Nagano Pref., 1 1 , 7. vii. 1957,

M. Ohno leg. ; $2{ }^{7} 3$ ㅇ, 22-25. vii. 1961, R. Ishikawa and K. Morimoto leg. Kasuga Bokujo, Mt. Tadeshinayama, Nagano Pref., 1우, 1. viii. 1971, R. \& F. Ishikawa leg.

Distribution: Japan (Mt. Jonen, Mt. Shiroumadake, Mt. Tadeshinayama).

The adults were captured by turning stones on the ground.

Nakane (1964) described a new subspecies, autumnalis, on a female from the same locality of the nominate subspecies by the following characters: "Upper surface uniformly dark reddish brown, apex of each elytron shortly pointed, rostrum longer and legs slenderer". With the courtesy of Prof. Nakane, I have examined the type. It is a iittle teneral and slightly deform- 


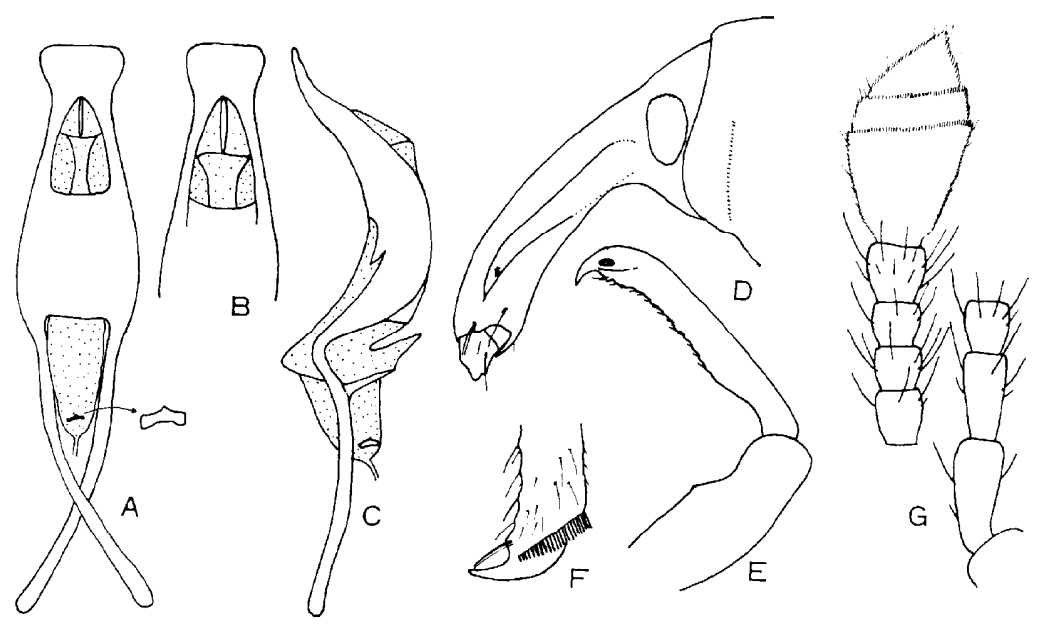

Fig. 35. Metahylobius jonensis Nakane, male. A : Penis, dorsal. B : Ditto, apex. C : Ditto, lateral. D : Head and rostrum. E : Fore tibia. F : Apex of hind tibia. G : Antenna.

ed. I have not seen the other material just fit the description, but strongly doubt the validity of this subspecies. Why two subspecies live in the same place?

Metahylobius rubiginosus sp. nov. (Figs. 36; $47 \mathrm{C}$ )

Male. Dark reddish brown, median part of rostrum blackish, bare parts of prothorax and elytra generally dark brownish to blackish, antennae and tarsi reddish brown, forehead and pronotum with sparse ochreous small scales, which being a little denser on each side and almost bare before and behind the admesial area of pronotum, elytra with indistinct bands of similar scales, the same scales denser on the apical half of first interval and on the third interval behind declivity. Underside with sparse yellowish grey fine setae, the setae a little longer and denser on the median part of fifth ventrite, trochanters each with a seta in general, fifth ventrite with a pair of small setal tufts.

Head with dense small punctures; forehead between eyes a little narrower than the base of rostrum, but distinctly wider than the middle, with or without a median depression; eyes oblong oval, marginate with shallow sulcus on dorsal and posterior margins. Rostrum almost as long as pronotum, gently curved, densely punctate, the punctures becoming smaller to the apex, neither sulcate not carinate excepting a small median longitudinal fovea between antenna1 sockets. Antennae with second segment of funicle a little shorter than the first $(13: 15)$, twice as long as the third, third to sixth segment similar in shape, about as long as wide, seventh segment 1.2 times as long as the sixth, club compact, first segment longer than the rest, second segment short. 

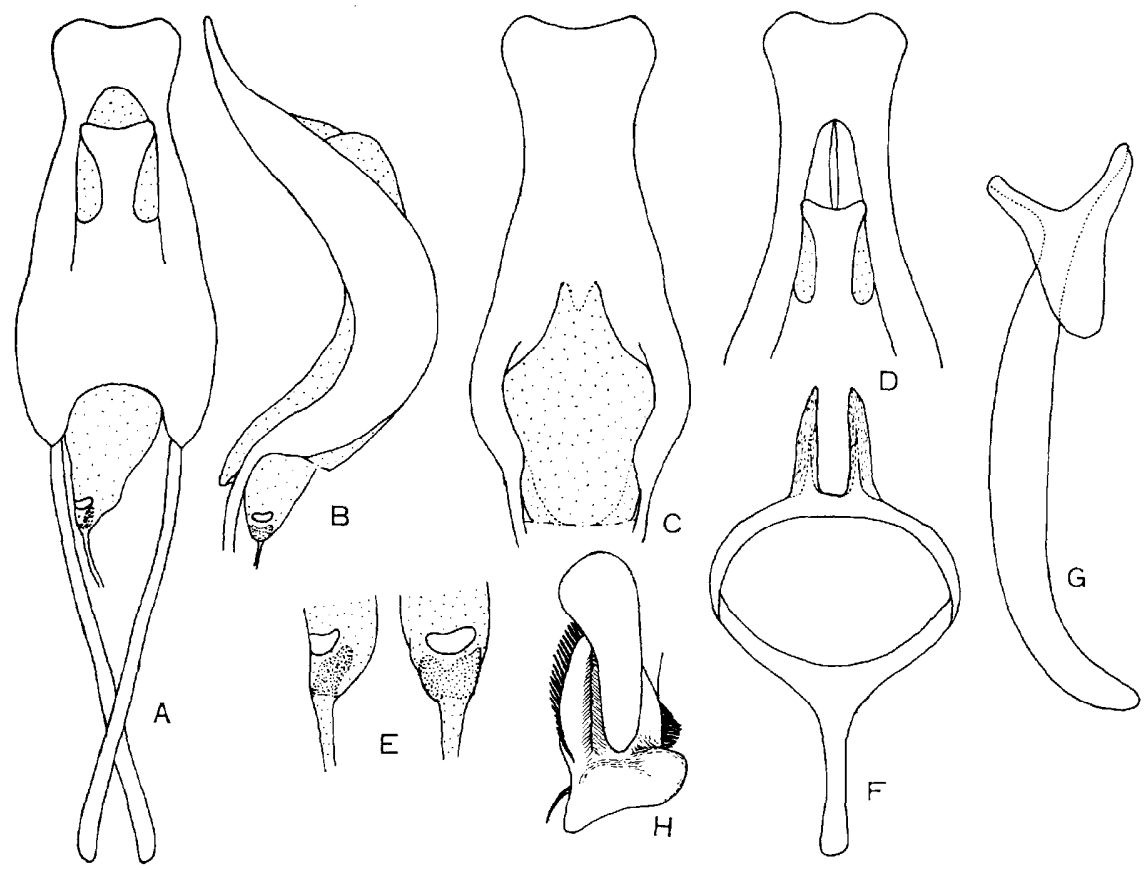

Fig. 36. Metahylobius rubiginosus sp. nov. A : Penis, dorsal. B : Ditto, lateral. C: Ditto, ventral. D: Apex of penis. E: Gonopore, lateral and dorsal. F: Tegmen and parameres. G: Ninth sternite. H. Apex of hind tibia, showing internally expanded uncus.

Prothorax a little broader than long, rounded laterally, widest at or a little before the middle, subapical constriction obsolete dorsally, postocular lobes weak; disk uneven, coarsely confluent-punctate and with shiny convex granules, each of the granule bearing a scale, anterior margin wrinkled-punctate and not granulate, median carina on the anterior half glossy.

Scutellum small, triangular, bare, shiny.

Elytra dilated posteriorly from humeri to a point above hind coxae, then parallel-sided to declivity, broadly rounded at apex, conjoint apex triangularly notched at suture; striae with small punctures, interstices between them convex forming shiny low granules, lateral area with large punctures, posterior area more regularly punctate-striate, not granulate; first interval convex at the curving area on declivity, first, third and fifth intervals wider than the others and with one or two irregular rows of large and small granules, the other intervals each with a rather regular row of granules, third, fifth and seventh intervals slightly higher, third interval weakly costate behind declivity, fifth and seventh intervals forming weak calli on declivity, behind the calli the granules becoming sparser.

Prosternum before coxae wrinkled-punctate, metasternum and first ventrite densely punctate, second ventrite with punctures smaller in the middle, 
third to fifth ventrites with dense small punctures, first and second ventrites broadly depressed in the middle, first suture very deep on each side and arched anteriorly in the middle.

Femora with obtuse tooth. Tibiae expanded internally at basal third and serrate thence apically, uncus of hind tibiae dilated internally.

Length : 8. 1-10.5 mm (excl. rostrum).

Holotype ð (Type No. 2368, Kyushu Univ.), Mt. Kiso-Koma (Senjoshiki cirque), Nagano Pref ., 28. viii. 1962, K. Morimoto leg.

Paratypes: Same locality as holotype, $1 \precsim 3$ 우, 27. viii. 1962, K. Morimoto leg. Raichozawa, Mt. Tateyama, Toyama Pref., 1ð, 29. vii. 1956, M. Sato leg. Yonnoike, Mt. Ontake, Nagano Pref., 1ð, 4. viii. 1953, S. Uéno leg. Mt. Tateshinayama (9-gome, $1900 \mathrm{~m}$ \& Kasugabokujo), $1 \delta^{\circledR 1}$ 우, 30. vi. \& 1. vii. 1971, R. \& F. Ishikawa leg. Mt. Yatsugatake (Shibunoyu), Nagano Pref., 1ð, 29. vi. 1971, R. \& F. Ishikawa leg. Marunuma, Gunma Pref., 1우, 9. vii. 1975, H. Irie leg. Mt. Enasan, Gifu Pref., 1우, 29. v. 1976, Y. Hori leg.

Distribution: Japan (Alpine zone of central Honshu).

This new species is very close to jonensis Nakane, but generally larger, the pronotum is more wider and more strongly rounded at sides, the calli of elytra are more distinct, and the unci of hind tibiae in male are strongly dilated internally at base, and the penis is much larger and concave at apex.

\section{Subtribe Leiosomatina}

\section{Pentaparopion gen. nov.}

Type-species : Pentaparopion costatum sp. nov.

Rostrum weakly curved, almost parallel-sided in female, weakly spatulate in male, scrobes oblique, their posterior margins a little below eyes and confluent on the underside of rostrum. Antennae inserted into the dorso-lateral corners of rostrum, funicle five-segmented, club compact, first segment longer than the rest. Eyes small, lateral, convex, composed of about ten facets.

Pronotum with a median and a pair of lateral ridges, postocular lobes absent, anterior margin of prosternum not sinuate. Scutellum absent.

Elytra without humeri, widest in the middle, intervals strongly costate and granulate, the costae not reaching the base in even-numbered intervals, third and ninth intervals conjoint at apex.

Fore coxae very narrowly separated. Metasternum shorter than the diameter of mesocoxa. Metepisterna linear, metepisternal suture complete, hind coxae widely distant. Suture between first and second ventrites almost obsolete in the middle, second ventrite longer than the third and fourth combined.

Aedeagus with long struts of penis, internal sac simple.

This genus is close to Aparopion Hampe from Europe, but easily distinguished from the related genera by the number of the funicular segments. This 
is also close to Gonotrachelus Champion from the Seychelles in having the fivesegmented funicle, but the metepisterna are not covered by the elytra and the tibiae are armed each with uncus at inner apical angle.

Pentaparopion costatum sp. nov. (Figs. 37, 38 left)

Fale. Rusty brown, matt; derm almost bare, often with sparse fine setae on elytra, femora and tibiae with minute recumbent greyish setae, sterna and ventrites with very sparse minute scales.

Head reticulate with rugose punctures ; forehead between eyes a little narrower than the base of rostrum, with a median fovea; eyes small, composed of 9-12 facets. Rostrum a little shorter than pronotum. weakly curved, densely punctate, the punctures longitudinally arranged leaving vague median and a pair of lateral carinae, almost parallel-sided on basal two-thirds, then weakly dilated to the side of antenna1 sockets and parallel-sided at apex. Antennae with first segment of funicle robust, 1.5 times as long as the second, third to fifth segments subequal in length, $2 / 3$ times as long as the second, fifth segment transverse, club compact, first segment more than half the length of club.

Pronotum a little wider than long, widest in the middle, almost straightly narrowing posteriorly, subapical constriction strong at sides and weak on prosternum, disk with reticulate rugose punctures, lateral ridges narrower and granulate on apical third.
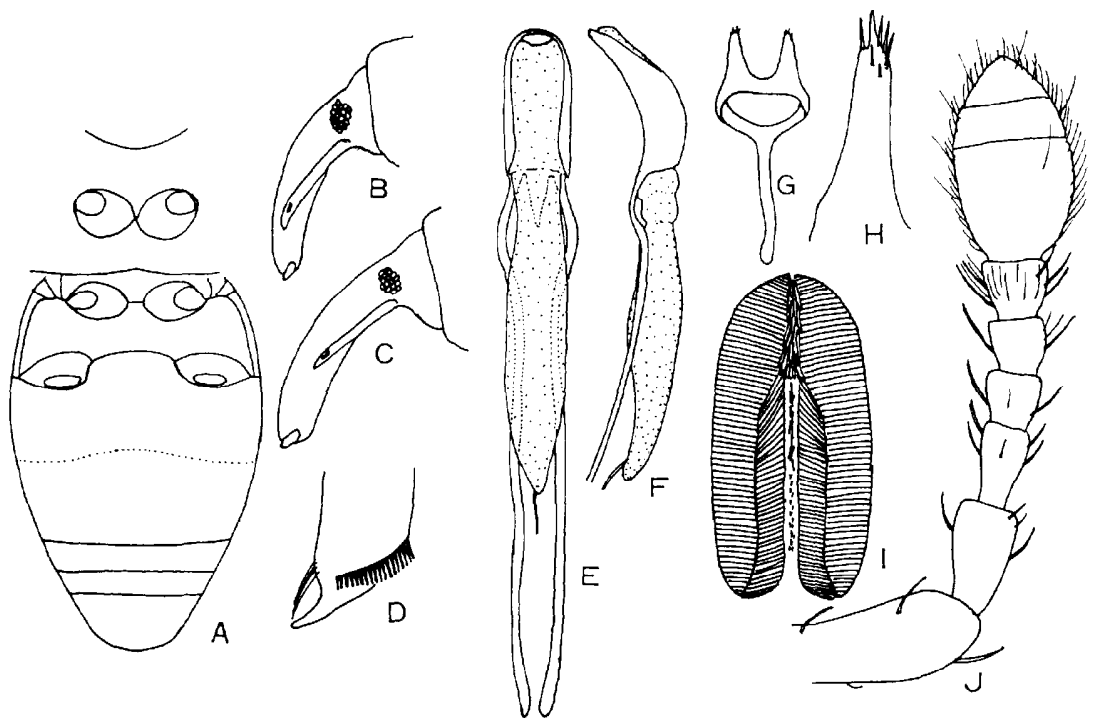

Fig. 37. Pentaparopion costatum gen. et sp. nov. A : Underside of thorax and abdomen. B, C: Headand rostrum (B : male, C : female). D : Apex of hind tibia. E : Penis, dorsal, F: Ditto, lateral. G: Tegmen and parameres. H: Left paramere, enlarged. I : Proventriculus. J : Antenna. 

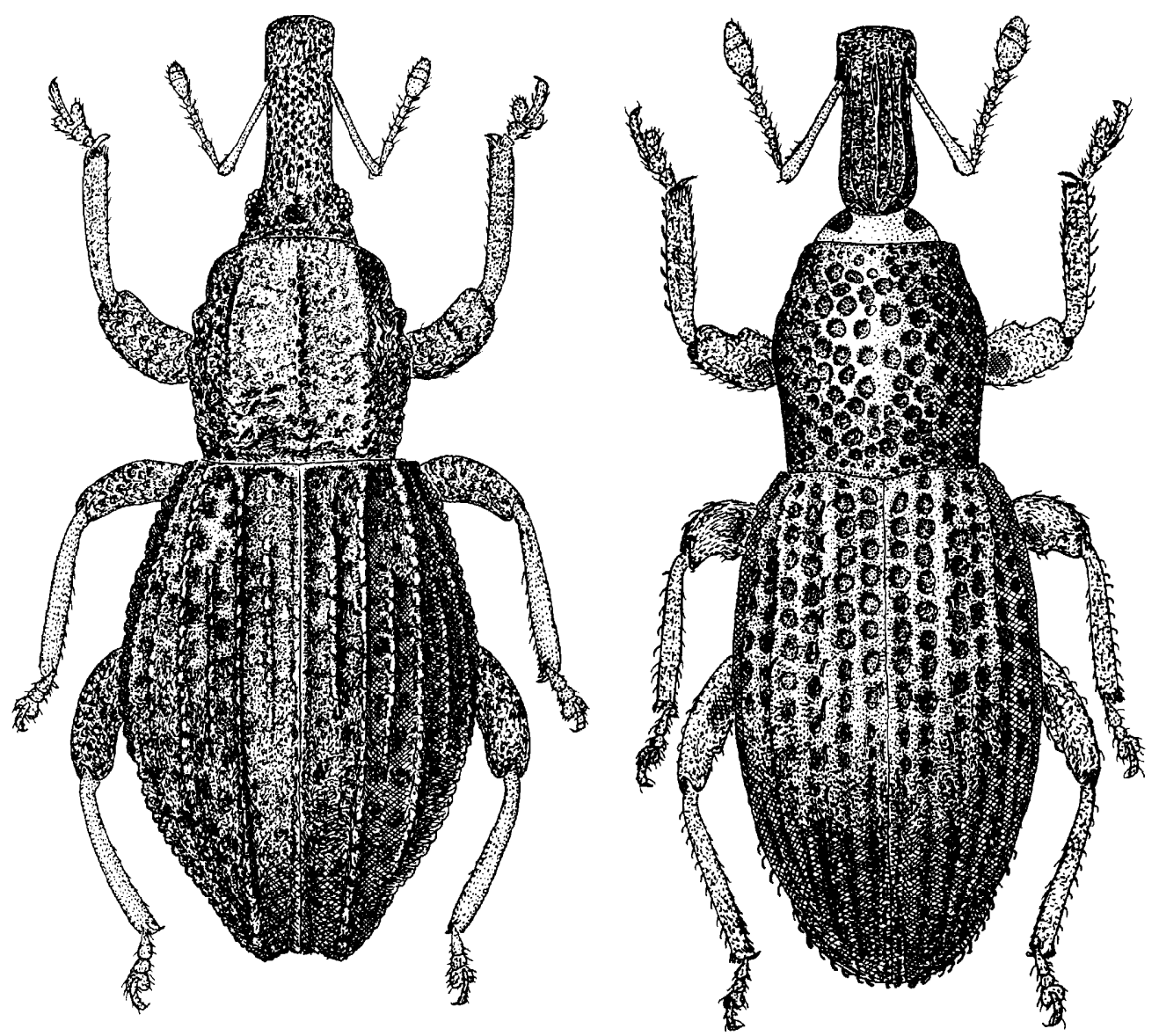

Fig. 38. Left: Pentaparopion costatum gen. et sp. nov., holotype. Right : Leptanchonus minatoi gen. et sp. nov., holotype.

Elytra widest in the middle, evenly rounded at sides, weakly convex dorsally; striae matt, with sparse ill-defined punctures in a row; intervals costate, costae on odd-numbered intervals reaching the base, while on even-numbered intersals obsolete at base and on declivity, costate part granulate, each granule often with a minute seta, ultimate striae entire.

Prosternum before coxae with large oblong punctures. Metasternum with large punctures arranged in two tansverse rows excepting side margins. First ventrite with shallow reticulate punctures, the punctures on second ventrite a little smaller and sparser in the middle, third and fourth ventrites with small indistinct punctures, fifth ventrite with dense punctures.

Femora edentate, with dense punctures. Tibiae very slightly incurved, outer setose fringe of tarsal groove weakly oblique. Tarsi short, first segment a little longer than the second, the latter transverse, third segment bilobed, 
claws simple, free.

Female. Rostrum as long as pronotum, not spatulate, antennae inserted in the apical third.

Length : 2.6-3.1 mm (excl. rosturm).

Holotype $\sigma^{\circ}$ (Type No. 2369, Kyushu Univ.), Mihara-rindo, Is. Hachijo. 22. iv. 1978, S. Miyakawa leg.

Paratypes: Same data as holotype, $3 ð 2$ 우.Kashidate, Is. Hachijo, 2 우, 23. iv. 1978, S. Miyakawa leg.

Distribution : Japan (Is. Hachijo).

Mr. S. Miyakawa extracted these specimens from soil by using the Berlese funnel.

\section{Subtribe Anchonina}

\section{Otibazo Morimoto}

Otibazo Morimoto, 1961, Kontyû, 29: 25; Morimoto, 1962, Journ.Fac Agr., Kyushu Univ., 12:

64. Type-speceies : Otibazo nagasakiensis Morimoto, by original designation.

Eyes small, latero-ventral in position, composed of about 20 facets; antennal scrobes oblique, passing beneath the base; antennae with funicle sevensegmented, club oval, first segment shiny, as long as the rest. Scutellum absent. Elytra glabrous, neither sulcate nor punctate, entirely smooth. Metasternum very short, middle and hind coxae almost touching. Metepisternal suture fine. Metepisterna parallel-sided, narrow. Abdominal process truncate, a little narrower than a coxa, second ventrite a little longer than the third. Femora unarmed, inner and outer margins of femora and tibiae densely scaled and haird in entire length. Tarsi with third segment not bilobed, claws minute, simple, free.

The edaphic weevils of the present genus have been known only by two species up to the present. I have been accumulating the materials from the various parts of Japan, and the result will be published before long. Part of the result shows that the every species has a small range of distribution and many species will be discovered from the southern Japan. Most of them can be distinguished only by the structures of aedeagus.

\section{Otibazo nagasakiensis Morimoto}

Otibazo nagasakiensis Morimoto, 1961, Kontyû, 29: 26 (Nagasaki City); Ejima et al, 1981, Natural History of the GotoIsls.: 310 (Is. Nakadori).

Distribution: Japan (Nagasaki City and Goto Isls.).

\section{Otibazo morimotoi Nakane}

Otibazo morimotoi Nakane, 1963, Fragm. Coleopt., (9) : 36 (Mt. Iwawaki) ; Nakane, 1963, Icon. Ins. Jap. Col. nat. et., II: 368, pl. 184, fig. 24 (Honshu, Kyushu) .

Distribution : Japan (Honshu, Kyushu-after Nakane, 1963). 


\section{Leptanchonus gen. nov.}

Type-species : Leptanchonus minatoi sp. nov.

Head globose, smooth ; rostrum robust, constricted at base, weakly curved ; antenna1 scrobes passing beneath the base of rostrum and narrowly separated behind; eyes oblong-oval, flat, minutely facetted. Antennae inserted at about one-fourth from apex of rostrum, funicle seven-segmented, club compact, first segment longer than the rest.

Prothorax with weak ocular lobes, anterior margin of prosterum deeply concave. Scutellum absent.

Elytra without shoulders, regularly punctate-striate, ultimate stria conjoint to the penultimate above hind coxa.

Fore coxae contacted. Mesosternal process narrow. Mesepisternal suture faint. Mesepimeral suture obsolete. Metasternum much shorter than first ventrite. Metepisterna linear. First ventrite longer than the second, suture between them obsolete in the middle, second ventrite as long as the third and fourth combined. Abdominal process a little narrower than a hind coxa.

Femora with obtuse tooth. Tibiae straight, fore tibia almost rectangularly truncate at apex, outer setose fringe of tarsal groove of hind tibia weakly oblique. Tarsi spongy beneath, third segment bilobed, claws of normal size, simple, free.

This genus belongs to the subtribe Anchonina, which is predominant in the Neotropical region and only two genera, Euthycodes and Otibazo, have been recorded from the Oriental Region. The present new genus is easily distinguished from the known genera by the following points : Eyes flat, not convex; elytra without shoulders ; antennae with seven-segmented funicle ; fore tibiae almost rectangularly truncate at apex ; tibia1 unci arise at the inner apical corner.

Leptanchonus minatoi sp. nov. (Figs. 38 right, 39)

Male. Dark brown, matt; rostrum and punctures with dirty brown amorphous covering ; dorso-lateral area of pronotum, apical area of elytra, femora and tibiae clothed with minute scales; elytra with recumbent brownish hairs on the alternate intervals, punctures in the striae each with a minute brown scales.

Head globular, lighter brown than body, glabrous, puncticulate. Rostrum constricted at base, with five small carinae, median carina narrowly bifolked at the middle and conjoint again a little behind the apex. Antennae with scape weakly widening distally, with minute scales on anterior margin, first segment of funicle 1.6 times as long as the second, twice as long as the third, third to sixth segments subequal in length, a little wider than long, seventh segment rounded, club compact, first segment longer than the rest.

Pronotum a little longer than wide (45:38), widest at apical third, then 

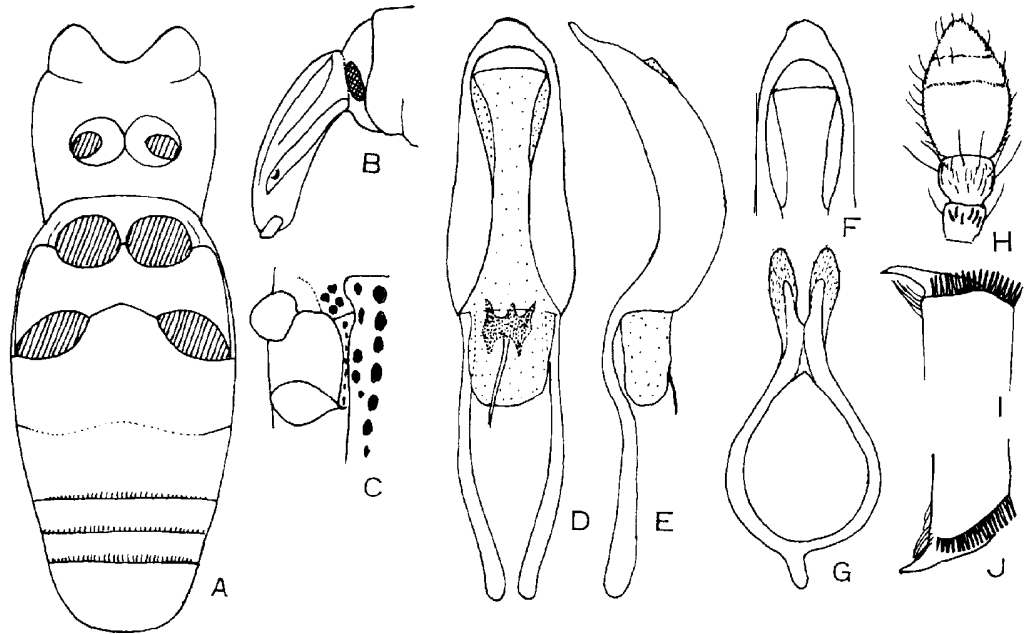

Fig. 39. Leptanchonus minatoi gen. et sp. nov., holotype. A: Underside of thorax and abdomen. B : Head and rostrum. C : Lateral pieces of metathorax. D : Penis, dorsal. E : Ditto, lateral. F : Apex of penis. G: Tegmen and parameres. H : Distal segments of antenna. I : Apex of fore tibia, J : Apex of hind tibia,

straightly narrowing posteriorly, subapical constriction distinct on lateroventral surface, obsolete dorsally, disk with large punctures.

Elytra $7 / 4$ times as long as wide, widest in the middle, evenly rounded laterally, striae with foveate punctures, which becoming smaller posteriad behind the middle, first and second striae reaching apex; intervals smooth, alternate intervals slightly elevated, fourth and sixth, and seventh and ninth intervals conjoint resectively at declivity.

Underside with coarse punctures except for third and fourth ventrites, which being almost smooth with fine punctures at sides.

Aedeagus with penis curved, bluntly pointed at apex, not membraneous on the ventral surface.

Female. Unknown.

Length : 4.6-5.4 $\mathrm{mm}$ (excl. rostrum).

Holotype $\sigma^{-}$(Type No. 2370, Kyushu Univ.), Tsudurafuchi, Shirahama, Wakayama Pref ., v-ix. 1978, H. Minato leg.

Paratype: Ohnogahara, Kochi Pref., 1ð, 3-5. viii. 1954, K. Morikawa leg. Distribution : Japan (Honshu, Shikoku).

These specimens were extracted from soil by using the Berlese funnel.

Tribe Lithinini

The tribe Lithinini contain some heterogeneous genera atpresent.

Niphades and Niphadonyx form a distinct group having the following characters : claws appendiculate, proventriculus with anterior plate formed of transverse rows of short spines, and prosternum deeply excavated with sharp late- 
ral carinae.

Nipponiphades was once treated as synonym of Seleuca by Voss (1958). But it is a valid genus differing from Seleuca as follows: prosternum deeply excavated, inside of the excavation bare, fore coxae contiguous, and ultimate stria of elytra conjoint with the punultimate above hind coxa.

Seleuca is an isolate genus in the tribe Lithinini, having the follwing characters: claws simple ; rostrum separated from head by depression; antennal scrobes oblique, passing beneath the base of rostrum; internal sac of penis with two pairs of characteristic appendages; and fore coxae narrowly separated. This genus is similar to Cotasteromimus in some characters and Seleuca horridula Voss, 1949, from China is probably a species of the latter.

The tribe Lithinini in the sense of Marshall, 1932, should be separated into several tribes as partly did by Voss, 1965, on African genera. But the materials before me are not sufficient to advance discussion at present.

$$
\text { Key to Genera OF the tribe Lithinini in Ja Pa }
$$

$l(2)$ : Claws appendiculate ; rostrum robust, contiguous with frons ; abdominal process narrower than a coxa; antennal scrobes weakly oblique, entirely

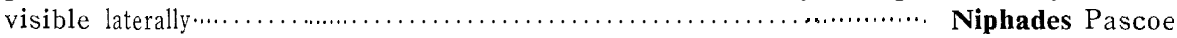

2(1): Claws simple; rostrum separated from forehead by a transverse impression or its dorsal outline forming an angle with forehead ; abdominal process broader than or as broad as a hind coxa; antennal scrobes oblique, passing beneath the base of rostrum.

3(4): Forehead between eyes half as broad as the base of rostrum; prosternum deeply excavated, its inside bare ; fore coxae contiguous ; ultimate stria of elytra conjointed with the penultimate above hind coxa ……. Nipponiphades Kôno

4(3): Forehead between eyes as broad as the base of rostrum; prosternum shallowly depressed, its inside punctate and the lateral carinae weak; front coxae narrowly separated ; ultimate stria of elytra entire …. Seleuca Pascoe

\section{Niphades Pascoe}

Niphades Pascoe, 1871, Journ. Linn. Soc. Lond., Zool., XI: 174; Kôno, 1934, Journ.Fac. Agr., Hokkaido Imp. Univ., XXX111 (3) : 244; Voss, 1958. Decheniana, Beihefte 5: 47; Morimoto, 1963, Journ.Fac. Agr., Kyushu Univ., 21 :63 ; Aslam, 1963, Bull. British Mus, (Nat. Hist.), Ent., 13 (3) : 62; Voss, 1937, Senckenbergiana, XIX: 264; Voss, 1965, Ann. Mus. Roy. Afr. Centr., in-8 ${ }^{\circ}$, Zool., 138: 344; Chao \& Chen, Econ. Ins. Fauna China, 20: 132. Type-species : Niphades pardalotus Pascoe, by monotypy.

Scaphostethus Roelofs, 1873, Ann. Soc. Ent Belg., XVI: 191; Faust, 1886, Horae Soc. Ent. Ross., XX : 172. Type-species : Scaphostethus variegafus Roelofs, by monotypy.

Pseudoconotrachelus Voss, 1932, Wien. Ent. 'Zeit., 49: 64. Type-species Pseudoconotrachelus verrucosus Voss, by monotypy.

\section{Niphades variegatus (Roelofs) (Fig. 40)}

Scaphostethus variegatus Roelofs, 1873, Ann. Soc. Ent. Belg., XVI: 191 (Japon) ; Faust, 1890, Hor. Soc. Ent. Ross., XX: 172.

Niphades variegatus: Lewis, 1879, Cat. Col. Jap. Archipel. : 22; Faust, 1890, Horae Soc. Ent. Ross., XXIV: 469; Kbno, 1934, Journ.Fac. Agr., Hokkaido Imp. Univ., XXX111 (3) : 244; Voss, 1937, Senckenbergiana, XIX: 264; Voss, 1958, Decheniana, Beihefte 5: 47; 

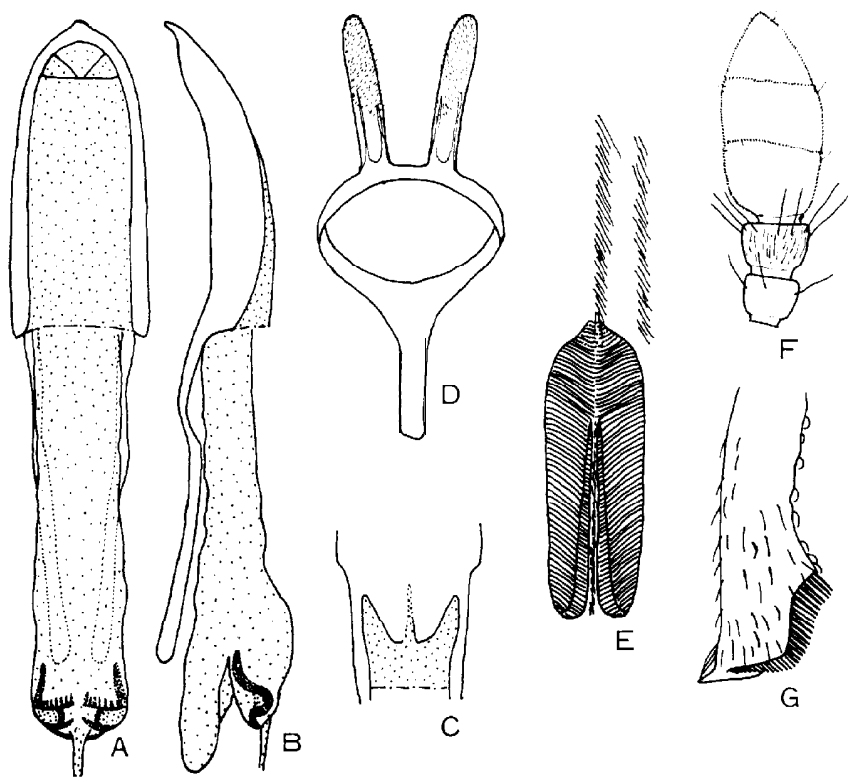

Fig. 40. Niphades variegatus (Roelofs), male. A : Penis, dorsal. B : Ditto, lateral. C : Basal part of penis, ventral. D : Tegmen and parameres. E: Proventriculus. F : Distal segments of antenna. G : Apex of hind tibia.

Kôno, 1950, Icon. Ins. Jap.: 1266, fig. 3648; Nakane, 1963, Icon. Ins. Jap. Col. nat. ed., II: 368, pl. 184, fig. 21; Chao \& Chen, 3980, Econ. Ins. Fauna China, 20: 141.

Specimens examined: 105 specimens from Hokkaido (Ashoro, Yubari, Mt. Meakandake), Aomori (Tsuta-onsen), Fukushima (Shinden, Yunohana), Niigata (Senami), Nagano (Ina, Omagari), Tochigi (Nikko), Gunma (Shinkazawa), Tokyo (Kobotoke), Shizuoka (Tentsuku-toge), Kyoto (Mt. Daihi, Kibune, Kurama, Hanazono), Okayama (Mt. Naginosen), Tottori (Mt. Daisen), Nara (Kasugayama), Kochi (Yanase, Jinzenji), Ehime (Omogokei), Fukuoka (Kashii, Mt. Homan, Nakabaru, Mt. Hikosan), Nagasaki (Mt. Kompira), Kumamoto (Tatsudayama, Ueki), Kagoshima (Cape Sata, Mt. Kirishima) and Is. Yakushima (Kosugidani, Miyanoura, Shiratani).

Distributron : Japan (Hokkaido, Honshu, Shikoku, Kyushu, Is. Yakushima), Amur.

h озт тrees: Pinus spp., Abies spp., Picea spp.

Several specimens from Is. Yakushima have slenderer elytra and parallelsided pronotum.

\section{Niphades verrucosus (Voss)}

Pseudoconotrachelus verrucosus Voss, 1932, Wien. Ent. Zeit., XLIX : 65 (Szetschwan). Niphades verrucosus: Voss, 1937, Senckenbergiana, XIX: 265; Voss, 1941, Mitt. Münch. Ent. Ge., XXXI : 888 (Unzen Shimabara) ; Voss, 1958, Decheniana, Benihefte 5: 47 (Kuatun); Chao \& Chen 1980, Econ. Ins. Fauna China, 20: 142. 
Distribution : China, Japan (Unzen Shimabara-after Voss, 1941).

Niphades variegatus is considerably variable in the general shape and the dorsal tubercles of elytra. N. variegatus and verrucosus are not separable by the keys made by Voss (1937 \&58). Chao and Chen (1980) distinguished them by the following points.

variegatus (Roelofs) : Elytra relatively shorter; tubercles on third, fifth and seventh intervals oblong, with depressed hairs on the tubercles, the other intervals with small tubercles; body length: 9-10 $\mathrm{mm}$.

verrucosus (Voss) : Elytra relatively longer, tubercles on the third, fifth and seventh intervals rather rounded, hairs on the tubercles erect, the other intervals with indistinct small tubercles ; body length $8.5 \mathrm{~mm}$.

I think that Voss (1941) identified a relatively slenderer individual of variegatus as verrucosus and recorded from Unzen Shimabara.

\section{Nipponiphades Kôno}

Nipponiphades Kôno, 1934, Journ.Fac. Agr., Hokkaido Imp. Univ., XXX111 (3) : 244; Voss, 1957, Ent. Rev. Japan, VIII: 35; Morimoto, 1963, Journ.Fac. Agr., Kyushu Univ., 12:

63. Type-species : Scaphostetus foveolatus Hustache, by original designation. Seleuca (partim): Voss, 1958, Decheniana, Beihefte 5: 47.

\section{Nipponiphades foveolatus (Hustache) (Fig. 41)}

Scaphostethus foveolatus Hustache, 1920, Bull. Mus. Hist. Nat. Paris, (6) : 495 (Asakawa, Mt.

Takao. Yose au col Kobotoke, Maruko, Nakano).

Seleucha fooeolatus: Morimoto, 1959, Enum. Ins. Mont. Hikosan, II: 80.

Nipponiphades foveolatus : Kôno, 1934, Journ.Fac. Agr., Hokkaido Imp. Univ., XXX111 (3) : 245 (Mt. Takao, Narita) ; Voss, 1957, Ent. Rev. Japan, VIII : 35 ; Nakane, 1963, Icon. Ins. Jap. Col. nat. ed., II : 368, pl. 184, fig. 23.

Specimens examined ; 23 examples from Kanagawa (Yugawara), Ehime (Mt. Ishizuchi) , Tokushima (Yuritori-gawa), and Fukuoka (Mt. Hikosan) .

Distribution : Japan (Honshu, Shikoku, Kyushu).

All of the specimens before me are seemed to be the female and two

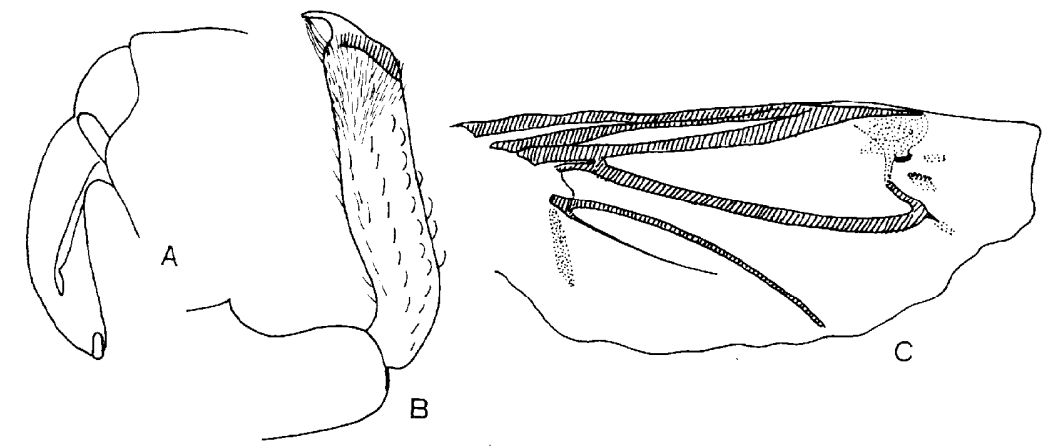

Fig. 41. Nipponiphades foveolatus (Hustache), female. A : Head and rostrum. B: Fore tibia. $\mathrm{C}$ : Hind wing. 
specimens dissected are brachypterous as illustrated.

\section{Seleuca Pascoe}

Seleuca Pascoe, 1871, Journ. Linn. Soc. Lond., Zool. XI: 173; Marshall, 1926, Philipp. J. Sci., 30: 354 (Key) ; Voss, 1940, Tijdschr. Ent., 83: 19 (Key) ; Voss, 1958, Decheniana, Beihefte 5: 47 (Key to Chinese spp.) ; Voss, 1957, Ent. Rev. Japan, VIII: 35 (Key to chujoi-allied spp .).

KeY tO SPECIES OF THE genus Seleuca in JAPAN

1(2): Fore femora each with a tooth; pronotum with a small shallow depression
at the middle near the base, its bare space very narrow, almost as wide
as the diameter of the puncture; hind wings not functional ...................

Seleuca satana sp. nov.

2(1): Fore femora each with a tooth and one to four denticles.

3(4): Pronotum with a small unpunctured bare depression at the middle near the base ; hind wings functional, normal ............... Seleuca impressicollis sp. nov.

4(3): Pronotum without an unpunctured bare depression; hind wings short, not functional

Seleuca chujoi voss

\section{Seleuca chujoi Voss (Fig. 42)}

Seleuca chujoi Voss, 1957, Ent. Rev. Japan, VIII: 34 (Kuroson) ; Nakane, 1963. Icon. Ins. Jap. Col. nat ed., II: 368, pl. 184, fig. 22.

Specimens examined : Igashima, Niigata Pref., $1 \delta^{\star}$, 8. ix. 1964, K. Baba leg. Masutomi, Yamanashi Pref., 1 ð , 23. vii. 1956, H. Kamiya leg. Mt. Daihi, Kyoto Pref., $1 \delta^{\top}$ 우, 1. vi. 1958, T. Tomiwa leg. Kifune, Kyoto, 1ð, 15. vi. 1958, H. Konishi leg. Mt. Iwawaki, Osaka Pref., 3 그 2 우, 26. iv. 1953, Sawada leg. Akasai, Shiso-gun, Hyogo Pref., 1우, 3. vi. 1979, T. Takahashi leg. Tsuchigoya, nr. Mt. Ishizuchi, Ehime Pref., 1 우, 18. viii. 1980, K. Ishikawa leg. Mt. Tebako, Kochi Pref., $1 \succsim, 21$. vii. 1955, K. Kojima leg. Tosayama, Kochi Pref., 1 § 1 우.v. 1956, K. Morimoto leg. Mt. Hikosan, Fukuoka Pref., $2 \Im^{\circledR}$, 4. vi. 1958, K. Morimoto leg. ; 1 우, 13. vii. 1957, Y. Miyatake leg. Mt. Kumado, Fukuoka Pref., 1 꾸 1 우, 11. viii. 1959, Y. Miyake leg. ;1우, 2. viii. 1958, J. Nagao leg. Mt. Kirishima, Kagoshima Pref., 2우, 4. viii. 1950, R. Matsuda leg. Mt. Tatera, Tsushima, 1 우, 18. v. 1961, H. Kamiya leg.

Distribution : Japan (Honshu, Shikoku, Kyushu, Tsushima).

This species is commonly found on the dead or a little rotten trunk of the various broadleaved trees, and also collected by sifting the litter.

Seleuca chujoi rugulosa subsp. nov. (Fig. 43)

Differing from the nominate subspecies by the following points.

Elytra more strongly depressed before and behind the V-shaped scaly fascia, second and third intervals strongly convex behind the middle, third interval strongly convex at base, subapical calli stronger, scales a little longer and much denser.

Holotype ð (Type No. 2371, Kyushu Univ.), Is. Hachijo, 10. v. 1965, K. Baba leg. 


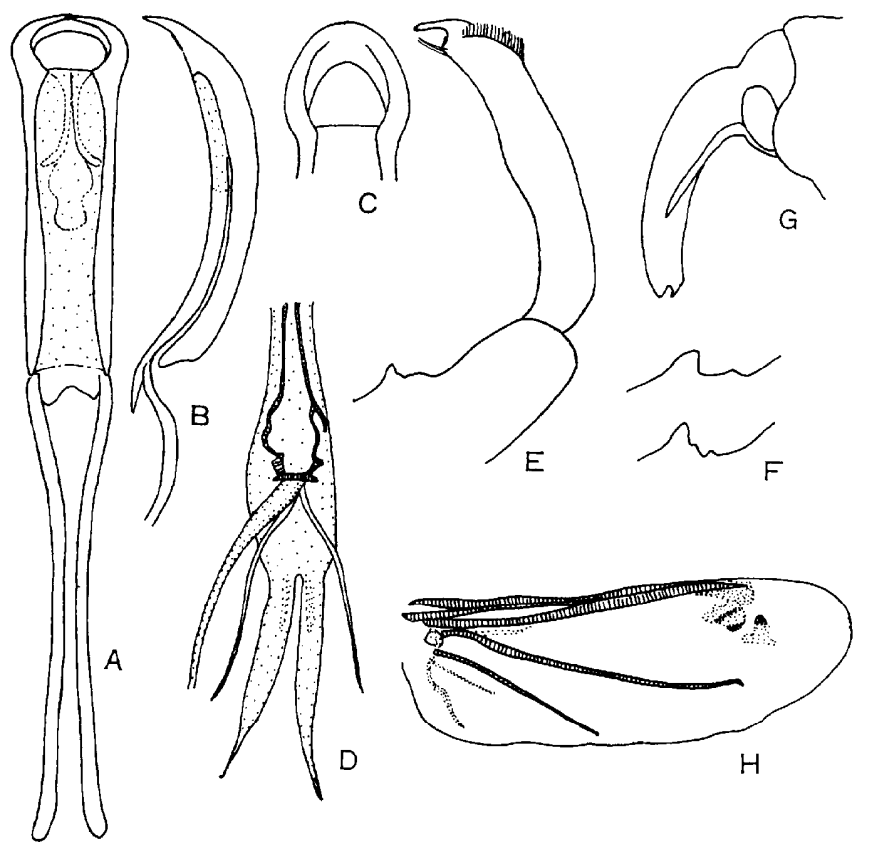

Fig. 42. Seleucá chujoi Voss, male (Mt. Hikosan). A : Penis, dorsal. B : Ditt 0, lateral. $\mathrm{C}$ : Apex of penis. D : Internal sac, dorsal. E : Fore tibia. F: Femoral tooth and denticles. G: Head and rostrum. H: Hind wing.

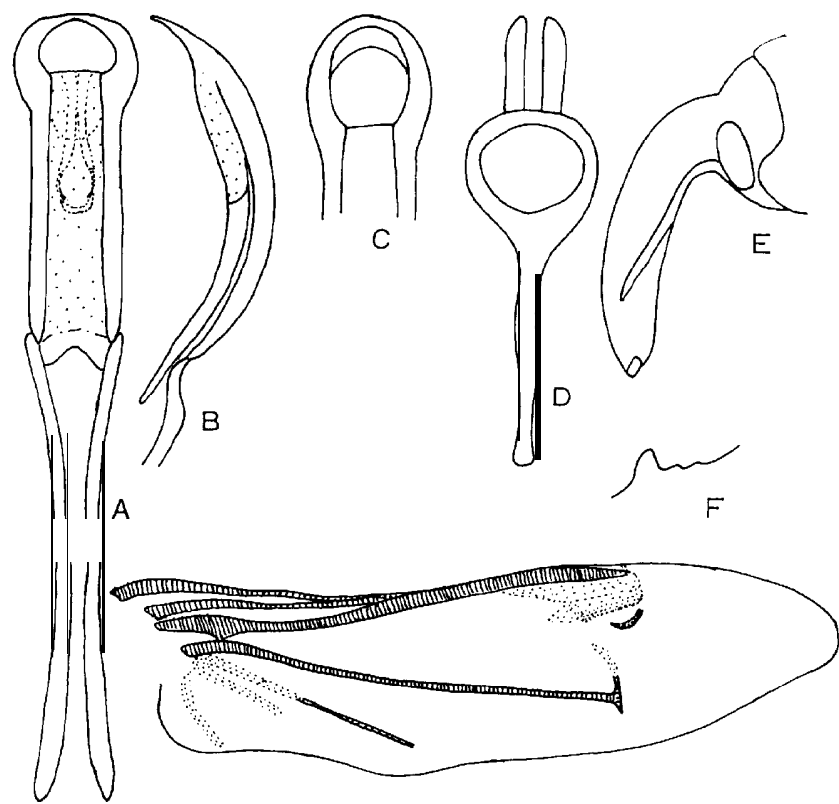

Fig. 43. Seleuca chujoi rugulosa ssp. nov., male (Is. Hachijo). A : Penis, dorsal. B : Ditto, la eral. C: Apex of penis. D: Tegmen and parameres. E: Head and ros.trum. $\mathrm{F}$ : Femoral tooth and denticles. G : Hind wing. 


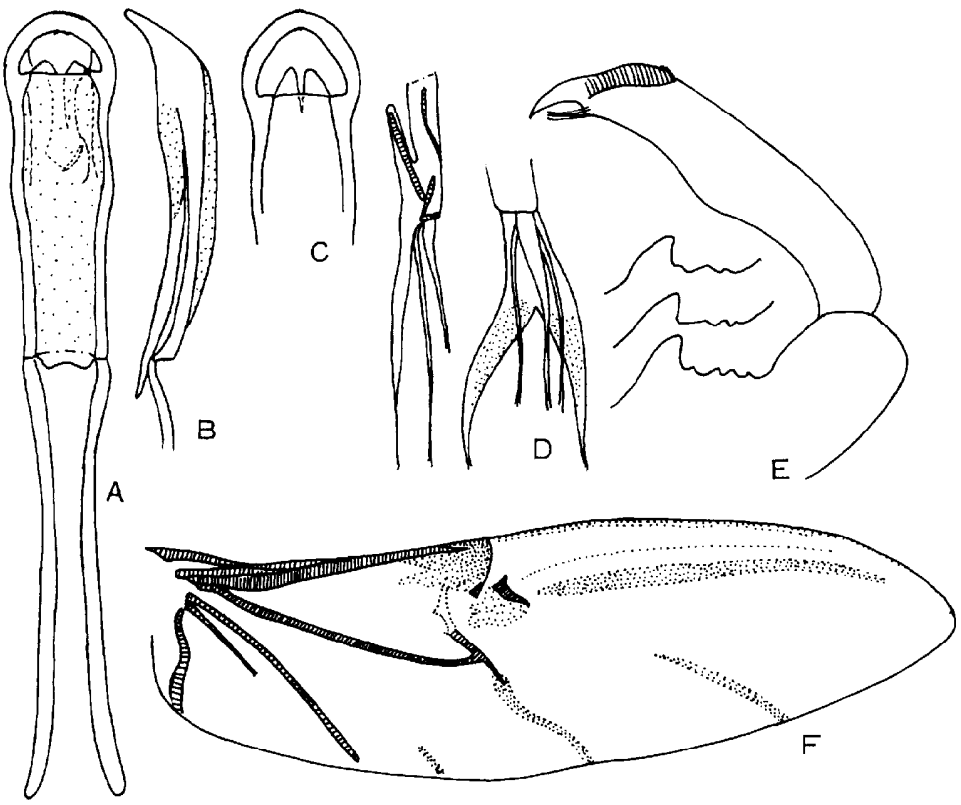

Fig. 44. Seleuca impressicollis sp. nov., male. A : Penis, dorsal. B : Ditto, lateral. C : Apex of penis. D : Internal sac, lateral and dorsal. E: Femoral tooth, denticles, and tibia of fore leg. $\mathrm{F}$ : Hind wing.

Paratype: Is. Mikura, 1 우, 12. v. 1967, Y. Kurosawa leg.

Distribution : Japan (Izu Isls.).

This subspecies is characteristic in having the rugose and more densely scaled elytra, but the aedeagus is almost identical with that of the nominate subspecies.

Seleuca impressicollis sp. nov. (Fig. 44)

Seleuca simillima: Chûjô (nec Voss), 1971, Mem. Fac.Educ. Kagawa Univ., II (202) : 40 (Amami-Oshima) .

Male. Dark reddish brown, antennae and apical part of rostrum reddish brown; scales ochreous, rostrum with sparse scales, pronotum with a pair of vague scaly stripes, elytra with dense scales forming a $\mathrm{V}$-shaped fascia from lateral margin a little behind humeri to the middle of suture, and dense patches on the base of third interval and on subapical calli, the other part of intervals each with one or two irregular rows of similar scales, the most scales subtruncate at apex and a few being acuminate apically; underside with small ochreous scales on sternum and fissured sparse hairs on ventrites.

Head subglobular, densely punctate, forehead between eyes as wide as the base of rostrum. Rostrum strongly curved at base, densely punctate, the punctures more or less longitudinally confluent leaving a median and two pairs of lateral irregular carinae, apical area bare and sparsely punctulate. An- 
tennae inserted into apical $1 / 5$ of rostrum, scrobes confluent on the underside of rostrum, its dorsal carinae curved ventrad at base and reaching the middle of the anterior margin of eye, first segment of funicle strongly clavate, twice as long as wide, second to seventh segments successively widening distally, seventh segment strongly transverse and annexed to club, the latter compact, first segment distinctly longer than the second.

Pronotum as long as wide, almost parallel-sided from base to the middle, then rounded to subapical constriction ; disk reticulately punctate, the punctures becoming larger towards side margins, with a faint short median carina before the middle, and with a small unpunctured bare depression at basal $1 / 4$, postocular lobes well developed.

Scutellum subcordiform, small, with several punctures.

Elytra $5 / 3$ times as long as wide, parallel-sided from humeri to the middle, apices conjointly rounded, striae with large punctures and much wider than interstices before the V-shaped scaly fascia, much narrower than interstices behind that, first to third striae especially narrowed and linear on declivity, third intervals weakly convex at base, subapical calli rather distinct, intervals neither costate nor tuberculate in the middle.

Prosternum deeply excavated at apex, weakly canaliculate before coxae, which bordered with obtuse carinae laterally; fore coxae narrowly separated. Mesosternal process truncate, transverse, with a pair of small tubercles. Metasternum with large punctures, which being a little smaller in the middle. Metepisternum with a row of small punctures. Venter with first to fourth ventrites sparsely punctate, their interstices much wider than the diameters excepting the side margins, where the punctures denser, fifth ventrite densely punctate.

Femora with three to four denticles beside the large tooth. Tibiae slightly incurved, weakly dilated internally in the middle.

Aedeagus as figured. (Fig. 44).

Female. Antennae inserted into apical $1 / 4$ of rostrum, first and second ventrites slightly convex.

Length: 4.3-5.1 mm. (excl. rostrum).

Holotype ðَ (Type No. 2372, Kyushu Univ.), Mt. Omotodake, Is. Ishigaki, 1821. iv. 1975, H. Irie leg.

Paratypes: Same locality as holotype, 1ð, 14. x. 1963, S. Uéno leg. Itajikigawa, Is. Iriomote, 1 욱, 8. vii. 1963, Y. Miyatake leg. Hiji, Okinawa, 1 우, 8. vii. 1974, Y. Mikage leg. Hatsuno, Amami-Oshima, 1ð , 13. vi. 1962, M. Sato leg. ;1우, 22. vi. 1971, I. Matoba leg.

Distriburion: Japan (Amami-Oshima, Okinawa, Ishigaki and Iriomote Isls.).

This species was once identified by Voss as simillima, but easily be separable from it by the presence of an unpunctured small depression on pronotum. 


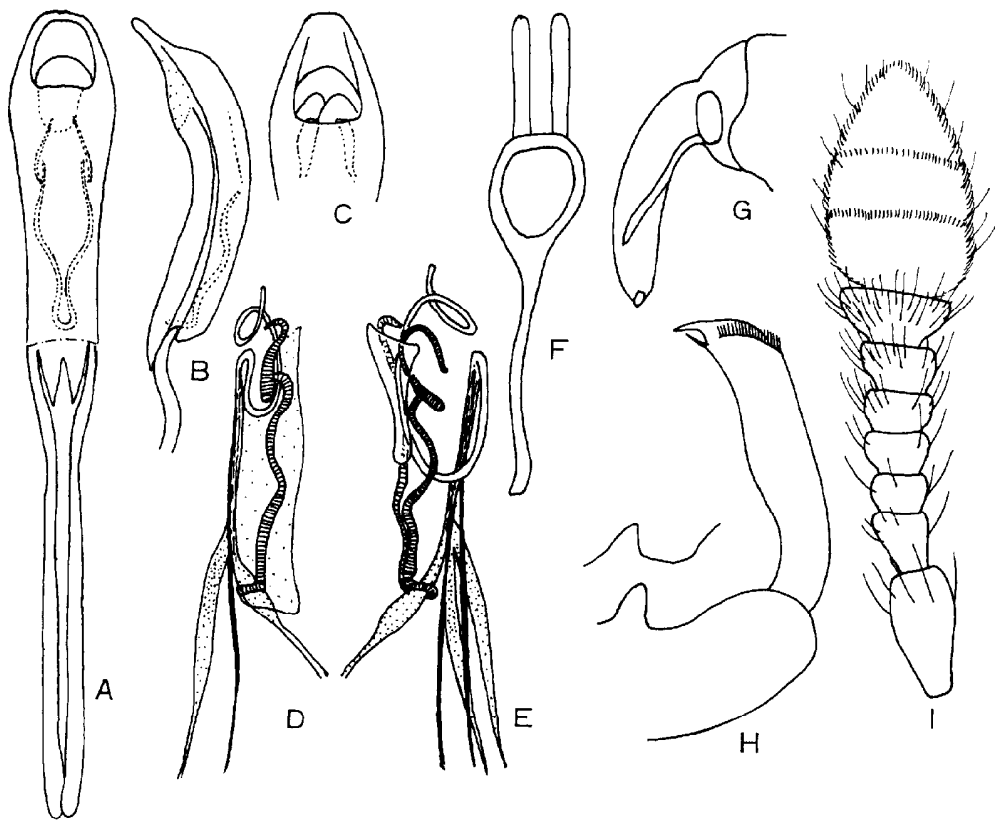

Fig. 45. Seleuca satana sp. nov., male. A : Penis, dorsal. B : Ditto, lateral. C : Apex of penis. D : Internal sac, lateral. E: Ditto, dorso-lateral. F: Tegmen and parameres. G: Head and rostrum. H : Femoral tooth and tibia of fore leg. I : Antenna.

Seleuca satana sp. nov. (Fig. 45)

Very close to impressicollis, but separable from it by the following points.

Pronotum widest at apical third, slightly and straightly narrowing posteriorly; disk with large punctures, median carina obsolete, a small depression a little before the base weaker and the bare space very narrow, almost as wide as the diameter of a puncture. Elytra with first to third striae regularly punctate, first to fourth intervals flat before the middle, and convex on declivity, sixth to eighth intervals and the basal area of third to fifth intervals subcostate, much narrower than striae. Femora without any trace of denticle beside tooth. Mesosternal process not tuberculate. Penis gradually narrowing apically and truncate at tip, internal sac with characteristic flagellum and sclerotized bands as figured.

Length : 4.0-4.5 mm. (excl. rostrum).

Holotype đ (Type No. 2373, Kyushu Univ.), Cape Sata, Kagoshima Pref., 25. v. 1958, K. Morimoto leg.

Paratypes: Same data as holotype, $1 \circlearrowleft$, Nakanoshima, Tokaras, 1 우, 25-30. v. 1975, H. Irie leg.

Distribution: Japan (Kagoshima, Is. Nakanoshima). 


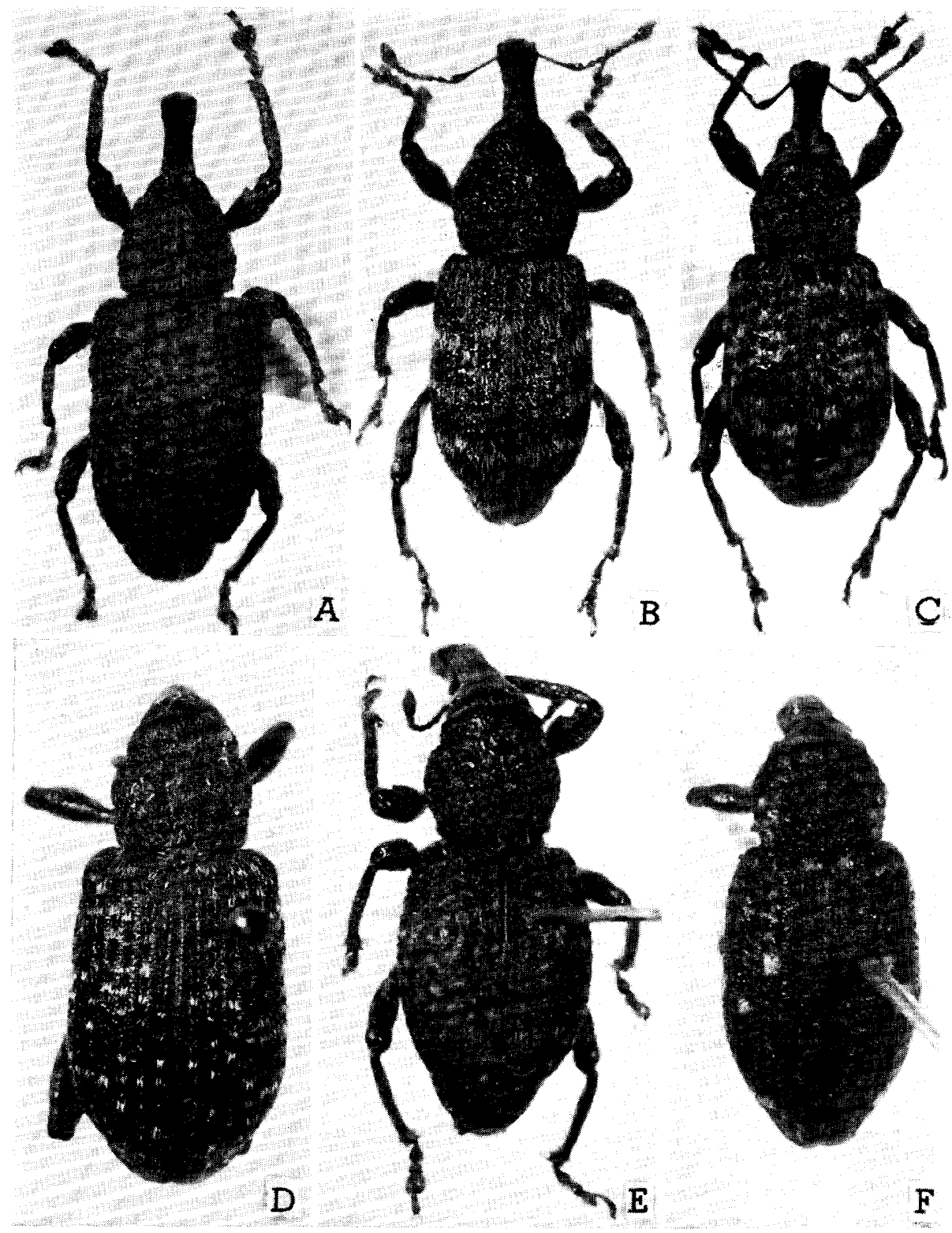

Fig. 46. A : Paramecops granulatus sp. nov., holotype. B :Hylobitelus futabae sp. nov., paratype. C:Hylobius adachii Kôno. D : Hylobius ezoensis sp. nov., paratype. E:Kyliparus lewsii (Roelofs). F :Lepyrus flavipunctatus (Zumpt), holotype. 

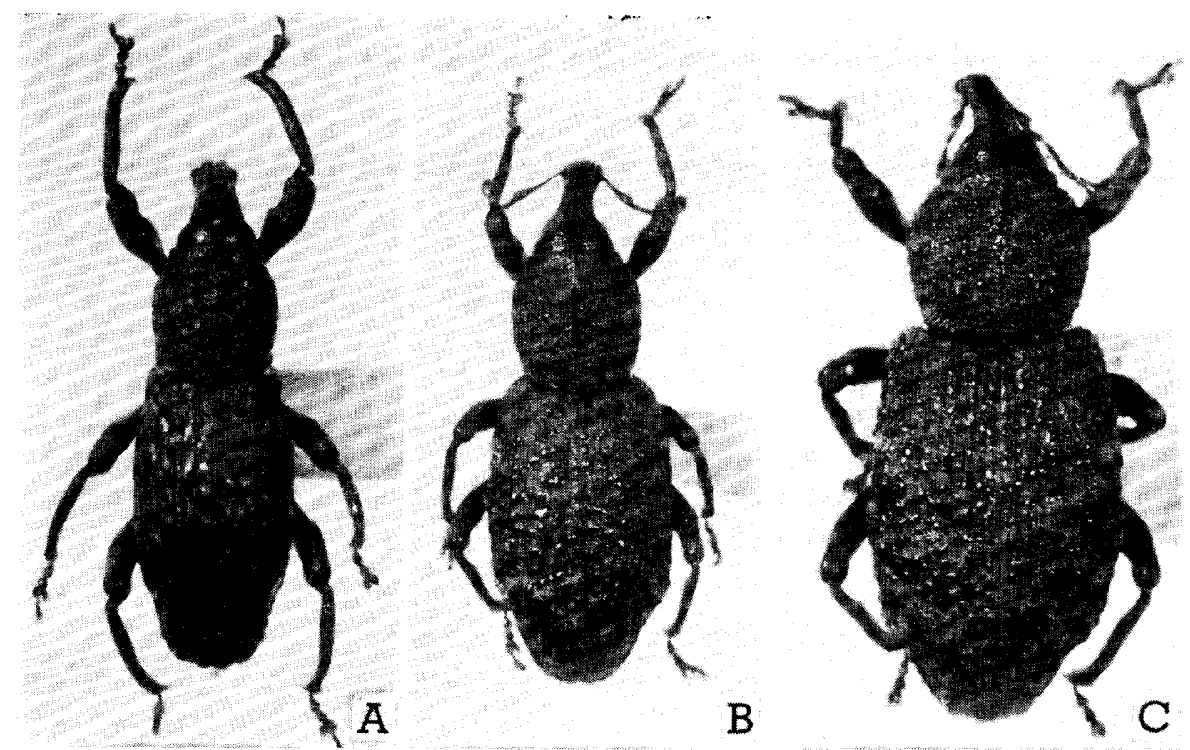

Fig. 47. A: Euthycus japonicus Heller. B:Metahylobius jonensis Nakane. C:Metahylobius rubiginosus sp. nov., paratype.

\section{References}

Aslam, N. A. 1963. On the genera of Indo-Pakistan Cleoninae and Hylobiinae. Bull. Brit. Mus. (Nat. Hist.), Enf., 13 (3) : 47-66.

Champion, G. C. 1902-06. Biologia Centrali-Americana, Insecta. Coleoptera. IV (4). Curculionidae (part), 750 pp., 35 tabs.

- 1914. The Percy Sladen trust expedition to the Indian Ocean in 1905. XIX. Coleoptera, Curculionidae. Trans. Linn. Soc. London, 2nd ser., Zool., XVI: 393-497, 2 pls.

Chao, Y. \& G. Chen 1980. Economic insect fauna of China. 20. Coleoptera, Curculionidae (I). 184 pp., 14 pls. (In Chinese)

Chû́jô, M. 1959. Description of a new Curculionid-beetles from Japan. Niponius, I(1) : 1-3. 1971. Coleoptera of the Loo-Choo Archipelago (III). Mem. Fac.Educ., Kagawa Univ., II (202) : 3-26.

and K. Morimoto 1956. On the olive weevil. Forest Protection News, Tokyo, 5 (10) : 6-8.

and E. Voss 1960. Neue Curculioniden-Subfamilie, -Gattungen und -Arten von Japan. Mem. Fac. Liberal Arts \& Educ., Kagawa Univ., II (94) : 1-17.

Csiki, E. 1934. Coleopterorum Catalogus, 134. Curculionidae : Cleoninae. 152 pp.

Dalla Torre, K. W. von and S. Schenkling 1932. Coleopterorum Catalogus, 122. Curculionidae : Hylobiinae. 112 pp.

Faust, J. 1882. Rüsselkäfer aus dem Amurgebiet. Deut. Ent. Zeit., XXVI: 257-295.

1887 . in Sahlberg. Bidrag till Tschuktsch-Halföns Insektfauna, Coleoptera och Hemiptera. Vega-Expeditionens Vet. Iak. IV : I-42.

1890. Insecta a cl. G. N. Potanin in China et in Mongolia novissima lecta. Curculionidae. Horae Soc. Ent. Ross., XXIV: 422-476.

- 1892. Curculioniden aus dem Malayischen Archipel. Stett. Ent. Zeit., 53: 184-228. 1892. Die Anchoniden-Gruppe. Deut. Ent. Zeit., 1892: 17-60. 
Heller, K. M. 1929. Neue Rüsselkäfer von den Philippinen und von Borneo nebst einen Verzeichnis entomologischer Sammler und Sammelplätze auf den Philippinen. $A b h$. Mus. Tierk. Volkerk. Dresden, 17 (3) : l-22.

-.-- 1931. Sauter's Formosa-Ausbeute : Curculionidae. Wien. Ent. Zeit., 48 : 96-112.

Hidaka, Y. 1921; Control of the camphur weevil, Hylobius macilentus. Bull. Forest Exp.Sta., 5: 17-28. (In Japanese)

Hirayama, S. 1940. Genshoku KochuZufu (Natural coloured illustration of the Coleoptera of Japan). 172 pp., 52 pls.

Hoff mann, A. 1954. Faune de France, 59. Coléoptères Curculionides (2e): 447-1208.

1963. Curculionidae. in Balachowsky, Entomologie applıquée a l'agriculture. I. Coléoptères $\left(2^{\mathrm{e}}\right) \cdot 874-1237$.

Hustache, A. 1920. Contribution à la faune entomologique du Japon: Coléoptères Curculionides. Bull. Mus. Hist. Nat. Paris, (6) : 493-499.

Iga, M. 1955. Coloured illustration of the insects of Japan. Coleoptera. (enlarged and revised ed.). 274 pp., 68 pls. (In Japanese)

Kamimura, K., T. Nakane, and N. Koyama 1964. Seasonal and altitudinal distribution of beetles in Mt. Jonen, the Japan Alps, with descriptions of new species, I. Sci. Rep. Kyoto Pref. Univ., 15 A: 17-38.

Kamiya, K. \& T. Adachi 1933. Genshoku KochuZufu (Coloured illustration of Coleoptera of Japan). 561 pls.

Kato, M. 1933. Genshoku Nihon Konchu Zukan (Three colour illustrated insects of Japan), IX, Coleoptera. 50 pls.

Kôno, H. 1928. Einige Curculioniden Japans. Ins. Mats., II: 1633177, 1 pl.

- 1933. Die Hylobiinen aus Formosa. Ins. Mats., VII: 182-189.

-- 1934. Die Japanischen Hylobiinen. Journ.Fac.Agr., Hokkaido Imp. Univ., XXXIII (3) : 223-248, 2 pls.

---- 1936, Die Käfer-Fauna vom Daisetsu Gebirge. Biogeogr., 1 (2) : 75-104, 1 p1.

1950. Curculionidae, in Esaki et al., Iconographia Insectorum Japonicorum. 1738 pp. (1259-1289) .

Lacordaire, T. 1863. Genera des Coléoptères. VI. Curculionides. $637 \mathrm{pp}$.

Marshall, G. A. K. 1932. Notes on the Hylobiinae. Ann. Mag. Nat. Hist., Ser. 10, IX: 341355.

- 1948. Entomological results from the Swedish expedition 1934 to Burma and British India. Novit. Zool., 42: 397-473.

Matsumura, S. 1907. Thousand insects of Japan, IV. 147 pp., 78 pls.

1931. Illustrated common insects of Japan. III. $128+183$ pp., 29 pls.

1931. 6,000 Illustrated insects of Japan Empire. 1497 pp.

Matsuzawa, H. 1958. Studies on the control of the olive weevil, Hylobius desbrochersi. Nogyo Kagawa, $10: 43-45$.

Y. Miyamoto, H. Okamoto \& S. Kawahara. 1957-58. Studies on the control of the olive weevil, Hylobius desbrochersi. Bull. Fac. Agr., Kagawa Univ., 8 (2) : 172-188; 9 (3) : 129135.

Morimoto, K. 1959. Brenthidae, Attelabidae, Apionidae and Curculionidae. Enumeratio Insectorum Montis Hikosan, II. Coleoptera : 74-87 pp., 2 pls.

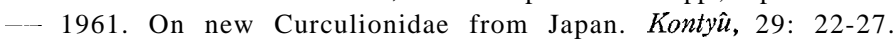

-- 1962. Taxonomic revision of weevils injurious to forestry in Japan. II. Hylobius orientalis and its allied species. Bull. Gov. Forest Exp. Sta., (143) : 1-8, 2 pls.

-- 1962. Key to families, subfamilies, tribes and genera of the superfamily Curculionoidea of Japan excluding Scolytidae, Platypodidae and Cossoninae. .I. Fac. Agr., Kyushu Univ., 12: 21-66.

1962. Preliminary check list of the families Curculionidae (II) and Rhynchophoridae of Japan. Sci. Bull. Fac. Agr., Kyushu Univ., 19: 341-368. 
Motschulsky, V. 1860. Coléoptères de la Sibérie orientale et en particulier des rives de l'Amour.Schrenck's Reisen Amurl., II : 156-174.

Nakane, T. 1963. New or little-known Coleoptera from Japan and its adjacent regions. XX. Curculionoidea. Fragmenta Coleopterol., (8/10): 31-40.

1963. Iconographia Insectorum Japnicorum Colore naturaliedita, II. 443 pp., 192 pls.

Pascoe, F. P. 1873. Contributions towards a knowledge of the Curculionidae. part II. Jo ourn.Linn.Soc. Lond., Zool., XI: 154-218, 4 pls.

- 1885 List of the Curculionidae of the Malay Archipelago collected by Dr. Odoardo Beccaari, L. M. D’Albertis, and others. Ann.Mus.Civ. Stor. Genova, II: 201-331, 3 pls.

Reitter, E. 1912. Bestimmungs-Schüssel der mir bekannten europäischen Gattungen der Curculionidae, mit Einschluss der mir bekannten Gattungen aus palaearctischen Gebiete. Varh.naturf. Ver. Brïnn, LI: 1-90.

- 1923. Die Hylobius-Artenaus Europa und den angrenzenden Gebieten. Wien. Ent. Zeit., 40: 21-24.

Roelofs, W. 1873. Curculionides recueillis au Japon par M. G. Lewis. Ann. Soc. Ent. Belg., XVI: 154-192, 2 pls.

1875. Curculiondes recueillis par M. J. van Volxem au Japon et en Chine. A $n n$. Soc. Ent. Belg., XVIII: Compt. Rend. : cxxviii-cxxxv.

-1880. Addition a la faune du Japon. Ann. Soc. Ent. Belg., XXIV: 5-31.

Schwenke, W. 1956. Zur Bionomie und Gradologie des grossen braunen Rüsselkäfers Hylobius abietis L. mit Bemerkungen über die Artbestimmung und Verbreitung von Hylobius abietis L. und H. pinastri Gyll. Beitr. z. Ent., 6: 245-273.

Solari, F. 1941. Revisione dei Neoplinthus Italiani ed alcune note di sistematica generale dei Curculionidi. Mem.Soc. Ent. Ital., XX: 43-90.

Van Dyke, E. C. 1928. The species of the genus Lepyrus Germ. in North America. PanPac. Ent., V: 53-58.

Voss, E. 1932. Weitere Curculioniden aus Yunnan und Szetschwan der Sammlung Hauser. Wien. Ent. Zeit., 49 : 57-76.

-.- 1934. Ueber neue und bekannte Rüssleraus Szetschwan und Manschurei. Ent. NachrBl., 8: 71-83.

- 1937. Ueber ostasiatische Curculioniden. Senckenbergiana, $19: 226$-282.

- 1941. Bemerkenswerte und unbeschriebene Rüsselkäferaus China und Japan. Mitt. Münch. Ent. Ges., 31: 887-902.

- 1957. Ueber einige weitere Curculioniden aus Japan. Ent. Rev. Japan, VIII: 33-39.

- 1958. Ein Beitrag zur Kenntnis der Curculioniden im Grenzgebiet der Orientalischen zur Paläarktischen Region. Decheniana, Beihefte 5 : 1-139.

- 1965. Mission zoologique de l'I. R. S. A. en Afrique orientale. (P. Basilewsky et N. Leleup, 1957). XCVII. Coleoptera Curculionidae. II. Ann. Mus. Ro y. Afr.Centr., in $-8^{0}$, Zool., $138: 293-377$.

Warner, R. E. 1966. A review of the Hylobius of North America, with a new species injurious to slash pine. Col. Bull., 20: 65-81.

Wood, S. L. 1957. The North American allies of Hylobius piceus (DeGeer). Canad. Ent., LXXXIX : 37-43.

Yokoyama, T. 1931. Zoku Nihon no Kochu (Illustrated Coleoptera of Japan, II). 159 pp., 20 pls.

Zumpt, F. 1932. Neue Rüsselkäferaus dem Japanischen Reich und Bemerkungen zu einem Hylobius-(Pagiophloeus) Arten. Kol. Rdsch., 18: 126-135.

-- 1936. Revision der paläarktischen Arten der Gattung Lepyrus Germ. Publ. Mus.

Ent."Pietro Ross?;, XTV (1) : 259-290.

1936. Ein neue Lepyrus-Artaus Japan. Ins. Mats., X: 146-147.

- 1938. Neue Rüsselkäfer aus der Paläarktischen Region. Ent.Blätt., 34: 81-88. 